\title{
HOOFDSTUK IV
}

\section{De Indonesische nationale beweging}

\section{Inleiding en overzicht}

De Nederlandse machthebbers in de Indonesische archipel hebben zowel ten tijde van de VOC als tijdens het koloniale bestuur talrijke conflicten met de inheemse bevolking gehad, maar ruim drie eeuwen lang waren dat altijd conflicten met afzonderlijke inheemse volken of rijken en niet met een al die volken omspannende Indonesische natie. Pas in het derde decennium van de twintigste eeuw ontstond in Nederlands-Indië een krachtige beweging die de hele inheemse bevolking van de kolonie als één natie zag en daarvoor onafhankelijkheid verlangde. Weliswaar hadden al in het begin van die eeuw verschillende emancipatiebewegingen het daglicht gezien, maar die hadden nog geen nationalistische grondslag.

De eerste emancipatiebewegingen richtten zich op bepaalde etnische groepen, zoals de Javanen, de Chinezen of de Indo-Europeanen. De bekendste daarvan was de in 1908 opgerichte Javaanse bond Boedi Oetomo. Naast zulke organisaties op etnische basis kwamen vakverenigingen tot stand, eerst alleen van Europese werknemers maar al spoedig ook van inheemse werknemers. Een derde grondslag voor aaneensluiting was de godsdienst: er werd een moslim-bond gevormd, de Sarekat Islam, die binnen enkele jaren uitgroeide tot de eerste Indonesische massabeweging. De etnische grondslag van Boedi Oetomo en de religieuze grondslag van de Sarekat Islam weerhielden deze bonden er overigens niet van ook politieke wensen naar te voren brengen, zoals die van inheemse medezeggenschap in het koloniale bestuur. Bovendien trad al in 1912 een echte politieke partij op, die zich zelfs uitdrukkelijk voor onafhankelijkheid uitsprak. Maar deze partij (wier aanhang vooral uit IndoEuropeanen bestond) werd door het gouvernement als onwettig beschouwd en bleef maar kort bestaan.

De meeste emancipatiebewegingen ontstonden binnen niet-Nederlandse bevolkingsgroepen. Niettemin leefde destijds ook onder Nederlandse ingezetenen enig verlangen naar meer mondigheid, omdat zij binnen het koloniale bestel geen enkele zeggenschap over het bestuur hadden. Dit bracht regering en parlement van Nederland ertoe in de kolonie een vertegenwoordigend 
lichaam in het leven te roepen, de Volksraad. Hierin kregen ook Indonesiërs zitting, naast een meerderheid van Nederlanders. De Volksraad werd in 1918 geïnstalleerd en al in datzelfde jaar leverden sommige Indonesische leden scherpe kritiek op het koloniale bestel en drongen zij aan op de vorming van een uit en door het volk gekozen parlement en de instelling van een daaraan verantwoordelijke regering.

In het begin van de eeuw stonden vrij veel Nederlanders welwillend tegenover de inheemse emancipatiebewegingen, maar die welwillendheid nam sterk af toen zulke bewegingen een politieke rol gingen spelen. Bovendien vond aan Indonesische kant een radicalisering plaats, onder meer onder invloed van marxistische actievoerders. Na 1920 verhardde zich ook het officiële koloniale beleid. Het gouvernement legde de politieke activiteiten van de Indonesiërs sterk aan banden. De Sarekat Islam, die al een deel van zijn massaaanhang verloren had, werd in diezelfde periode verzwakt door een machtsstrijd met de marxisten, die zich nu organiseerden als communistische partij. Een deel van de aanhang van deze partij kwam echter eind 1926 in opstand tegen het koloniale gezag, waarop dit gezag rigoureuze maatregelen nam die de communisten als politieke factor uitschakelden.

Intussen hadden enige Indonesische studenten die in Nederland studeerden een nieuwe politieke lijn uitgezet. $\mathrm{Zij}$ wensten nationale onafhankelijkheid voor Indonesië, waarbij zij alle inheemse ingezetenen van Nederlands-Indië als één Indonesische natie beschouwden. Ter bereiking van die onafhankelijkheid zou men zich moeten onthouden van samenwerking met de koloniale overheersers. Dit beginsel van 'non-coöperatie' hield op zijn minst in, dat Indonesiërs geen zitting zouden moeten nemen in door de overheersers ingestelde vertegenwoordigende lichamen zoals de Volksraad. De student Hatta was de voornaamste leider van deze groep, die ook het politieke denken in de kolonie zelf beïnvloedde.

Terwijl de Sarekat Islam hier sterk aan invloed had ingeboet en de communistische partij van het politieke toneel was verdwenen, kwam nu in Indonesië een nieuwe beweging op die zich zonder etnische of godsdienstige beperkingen tot de hele inheemse bevolking richtte. Gangmaker van deze eerste Indonesische massabeweging op zuiver nationalistische grondslag was de in 1927 opgerichte Partai Nasional Indonesia. Haar leider, Soekarno, toonde zich een begaafd volksmenner. De partij stelde zich nationale onafhankelijkheid ten doel en onderschreef het non-coöperatiebeginsel. Niettemin was zij bereid tot samenwerking met Indonesische groeperingen die het non-coöperatiebeginsel niet onderschreven. Onder meer Boedi Oetomo en de Sarekat Islam schaarden zich nu ook uitdrukkelijk achter de doelstelling van nationale onafhankelijkheid.

Regering en parlement van Nederland zetten in deze tijd nog enkele stappen tot wijziging van het koloniale bestel. Onder meer bepaalden ze dat 
de Volksraad voor de helft uit inheemse leden zou bestaan; omdat de Raad daarnaast ook enkele vertegenwoordigers van de Chinese en de Arabische bevolkingsgroep telde, zouden de Nederlandse leden er voortaan geen meerderheid meer vormen. Deze afschaffing van de Nederlandse meerderheid in de Volksraad wekte een storm van protest onder de Nederlandse ingezetenen van de kolonie.

De jaren dertig gaven in Nederlands-Indië een voortschrijdende polarisering van het politieke toneel te zien. Terwijl het Indonesisch nationalisme zich gestadig verbreidde, hielden de meeste Nederlanders hardnekkig vast aan het behoud van hun overheersende positie. Soekarno werd eind 1929 gearresteerd en bracht twee jaar in gevangenschap door. Zijn partij hield op te bestaan en binnen de nationale beweging ontstond interne verdeeldheid. Hatta keerde uit Nederland terug, maar stelde zich als een rivaal van Soekarno op. In 1933 en 1934 trad het koloniale gouvernement scherp op tegen de non-coöperatieve vleugel van de nationale beweging. Onder meer verbande het een aantal van haar voormannen, onder wie Soekarno en Hatta, naar afgelegen plaatsen binnen de kolonie. Het stond Indonesiërs niet langer toe voor nationale onafhankelijkheid te pleiten, behalve binnen de Volksraad waar vrijheid van spreken gold. Het zwaartepunt van de nationale beweging verschoof nu naar de coöperatieve vleugel. Haar belangrijkste vertegenwoordiger was Thamrin, leider van de Indonesische nationalisten in de Volksraad.

In deze zelfde periode deed Groot-Brittannië stappen in de richting van autonomie voor India, terwijl Amerika aan de Filippijnen zelfs volledige onafhankelijkheid toezegde. Daarentegen stelde Nederland zich steeds negatiever op tegenover de Indonesische verlangens naar meer zeggenschap. Het stootte daarmee ook invloedrijke Indonesiërs af die prijs stelden op behoud van een staatkundige band met Nederland. Enigen van hen gingen in 1939 met de voorstanders van nationale onafhankelijkheid samenwerken in een brede beweging die aandrong op de invoering van een parlementair stelsel in Indonesië, zoals al in 1918 in de Volksraad bepleit was.

Kort daarna werd Nederland door Duitsland bezet en week de Nederlandse regering naar Londen uit. Dit leidde aan Nederlandse kant niet tot meer begrip voor de Indonesische bezwaren tegen de koloniale verhouding. Het Nederlands-Indische gouvernement vond dat men in die verhouding geen enkele wijziging mocht aanbrengen zo lang Nederland niet bevrijd was. De kloof tussen de Nederlandse overheersers en de politiek bewuste Indonesiërs was dan ook wijder dan ooit, toen Japan in de eerste maanden van 1942 Nederlands-Indië veroverde. 


\section{Ontluiken van de Indonesische drang naar mondigheid}

Een nationale beweging die de hele inheemse bevolking van de kolonie als één natie beschouwde ontstond in Nederlands-Indië betrekkelijk laat in vergelijking met sommige andere koloniën. Gedeeltelijk kan dit worden toegeschreven aan het door de Nederlanders gevoerde taal- en onderwijsbeleid. Tot ver in de negentiende eeuw kenden de meeste Indonesiërs geen Nederlands of Engels; dit gold ook voor de meerderheid van de weinigen die konden lezen. Een belangrijke toegangspoort tot kennis van de wereld buiten de eigen landstreek bleef daardoor voor hen gesloten. Toen die poort eenmaal openging, voltrok de nationale bewustwording zich in hoog tempo.

Deze bewustwording kwam omstreeks 1900 op gang, toen steeds meer inheemsen onderwijs (en vooral ook westers onderwijs) gingen volgen. Zij begonnen de hele kolonie, waarvan de kaart de klaslokalen sierde, als hun eigen land te zien. Bij de aardrijkskundeles ontdekten zij dat het stamland van hun koloniale overheersers maar klein was, zowel in vergelijking met andere Europese landen als in vergelijking met Nederlands-Indië. Bij de geschiedenisles vernamen zij, dat dit land zijn onafhankelijkheid te danken had aan een opstand en een langdurige oorlog tegen vreemde overheersing. Op de middelbare scholen leerden zij bovendien over de Franse Revolutie en de Amerikaanse Onafhankelijkheidsoorlog en over de ideeën van vrijheid en gelijkheid die daarbij waren verkondigd. Terwijl honderden Indonesiërs aldus in Nederlands-Indië kennis maakten met westerse opvattingen, waren er ook al enkelen die in Nederland studeerden en daar de westerse invloed nog veel intensiever ondergingen.

Nationale bewustwording werd bovendien bevorderd door wat Indonesiërs nu dank zij westers onderwijs en onderzoek te weten kwamen over de geschiedenis van de Indonesische archipel voor de komst van de Europese kolonisatoren. Het bleek hun dat sommige inheemse culturen daar toen een hoog niveau bereikt hadden, waarvan onder meer een monumentaal kunstwerk als de Boroboedoer getuigde, en dat daar machtige rijken bestaan hadden zoals het Sumatraanse Sriwidjaja en het Javaanse Modjopahit.

In deze zelfde tijd werd de horizon van veel Indonesiërs verruimd door het verschijnen van diverse periodieken in het Maleis en andere inheemse talen. Het belangrijkste daarvan was Bintang Hindia (Ster van Indië), een veertiendaags tijdschrift dat in Amsterdam gedrukt werd en in Indië tienduizenden abonnees had. Het verscheen van 1902 tot 1907 en werd grotendeels geredigeerd door de Sumatraanse arts Abdoel Rivai, die in die tijd in Europa verbleef.

Eén van de facetten van het westers onderwijs was, dat de leerlingen in de eerste plaats beoordeeld werden op grond van hun kundigheden en prestaties. Dit contrasteerde met sommige Indonesische culturen waarin men men- 
sen in de eerste plaats beoordeelde op grond van hun afkomst en hun functie, en vooral met de Javaanse cultuur die een extreme nadruk op rang- en standsverschillen legde. Maar de door Indonesiërs in het westers onderwijs ervaren behandeling op basis van gelijkheid contrasteerde ook met de ongelijkheid van behandeling die hun verder in de kolonie ten deel viel. Die bestond niet alleen uit de wettelijke verschillen in rechtspositie tussen Inlanders en Europeanen, maar ook uit allerlei andere vormen van discriminatie en vernedering. Veel blanken maakten geen geheim van hun overtuiging dat de inheemse bevolking tot een inferieur ras behoorde. De inlander, zo zeiden zij, was dom, lui, onvolwassen en onbetrouwbaar. In hun mond werd het woord 'inlander' een uitdrukking van minachting.

Het westers middelbaar, beroeps- en hoger onderwijs was door zijn geheel Nederlandse opzet bijzonder zwaar voor inheemse scholieren en de meesten maakten hun studie dan ook niet af. Tegelijkertijd betekende dit, dat zij die hun opleiding wel voltooiden tot de meest intelligente en meest energieke Indonesiërs behoorden. Zij vormden in de koloniale samenleving het begin van een nieuwe elite tegenover de traditionele elite van de inheemse aristocratie. Hun opleiding bevorderde zowel hun zelfvertrouwen als hun verlangen om zich actief voor meer mondigheid in te zetten. Dit emancipatiestreven leidde in eerste aanleg tot de oprichting van moderne organisaties, onder meer op basis van etniciteit, beroep of religie. Een nationale politieke beweging liet niet lang meer op zich wachten.

De Indonesische nationale bewustwording werd ook gestimuleerd door de uitgesproken nationalistische gezindheid die in ditzelfde tijdsgewricht onder de Nederlanders heerste. Ook inheemse kinderen leerden het lied dat destijds het Nederlandse volkslied was en begon met de woorden 'Wien Neêrlands bloed in d'aders vloeit, van vreemde smetten vrij'. In 1913 werd de honderdste verjaardag van het herstel van de Nederlandse onafhankelijkheid ook in Nederlands-Indië uitbundig gevierd.

Dit betekent niet dat Indonesiërs alleen chauvinistische en racistische Europeanen ontmoetten. Vooral van de in steeds grotere aantallen uit Nederland overkomende vakmensen was een deel geheel vrij van zulke sentimenten. Daartoe behoorden verscheidene leraren bij het middelbaar onderwijs, die dan ook bijdroegen tot een opvoeding in liberale geest van hun Indonesische leerlingen. Hetzelfde gold voor sommige Nederlandse kostgezinnen van inheemse scholieren. Ook waren er hoge ambtenaren die zich met hart en ziel voor de emancipatie van de bevolking inspanden en persoonlijke contacten met ontwikkelde Indonesiërs onderhielden, zoals J.H. Abendanon, van 1900 tot 1905 directeur van onderwijs, eredienst en nijverheid, en G.A.J. Hazeu, van 1906 tot 1920 adviseur en regeringscommissaris voor inlandse en arabische zaken.

Hoe persoonlijk zulke contacten konden zijn, blijkt uit brieven die een 


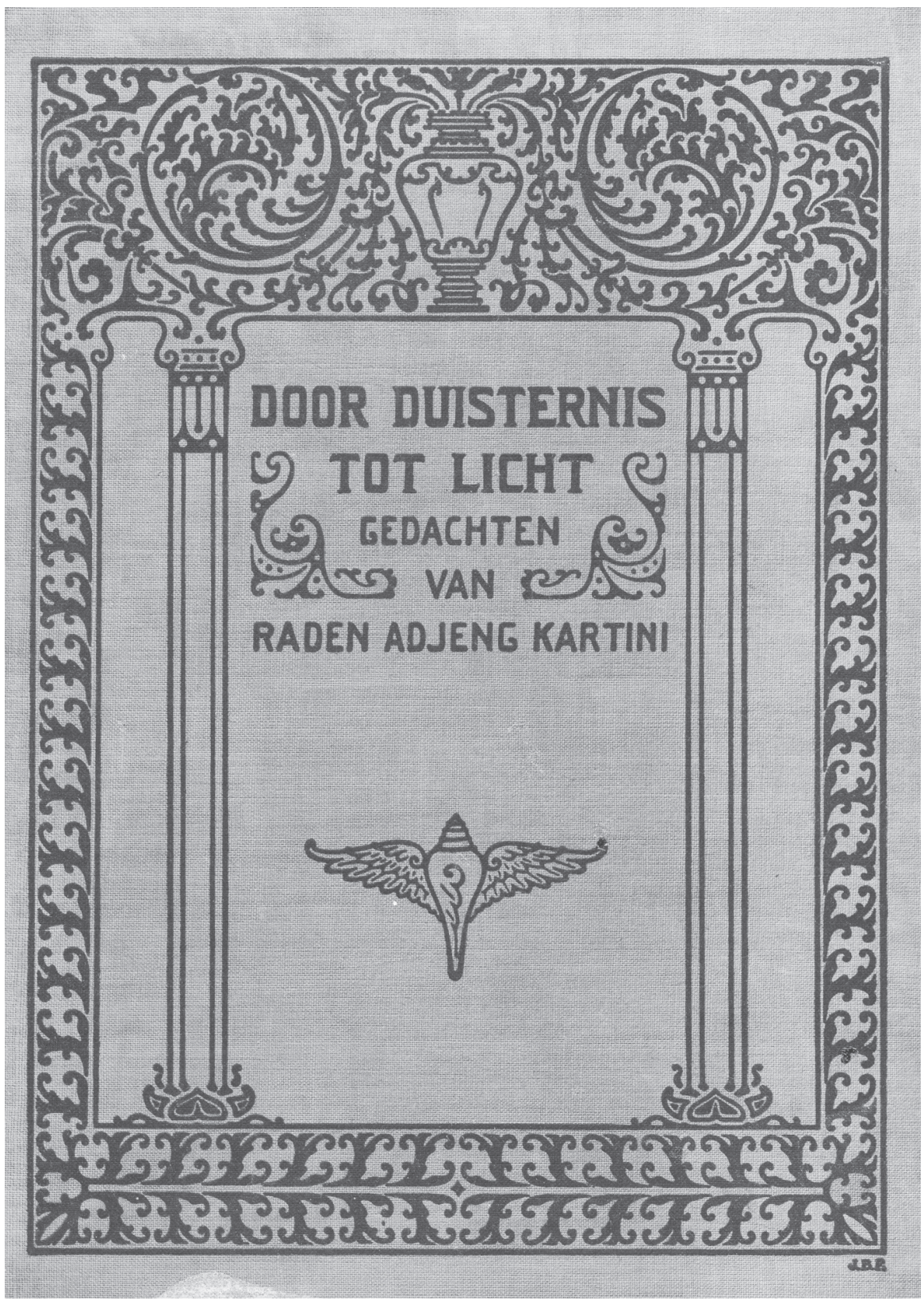

De Javaanse regentsdochter Kartini (1879-1904) schreef aan Nederlandse kennissen een groot aantal brieven, die in 1911 onder de titel Door duisternis tot licht in Nederland zijn gepubliceerd, waardoor men daar voor het eerst rechtstreeks kennis kon nemen van de gedachten en gevoelens van een inheemse ingezetene van Indonesië. 
Javaanse adellijke jongedame, Kartini, tussen 1899 en 1904 schreef aan een aantal Europese vriendinnen en vrienden. Kartini, die slechts vijfentwintig jaar oud is geworden, merkte op dat Nederland en de inheemse adel van de koloniale situatie profiteerden ten koste van het inheemse volk. Zij achtte onderwijs en opvoeding essentieel om die situatie te verbeteren en stelde daarbij al haar hoop op Nederlandse hulp. In 1911 publiceerde Abendanon in Nederland een aantal van haar brieven onder de titel Door duisternis tot licht. Dit boek, dat veel lezers vond, liet voor het eerst een breed Nederlands publiek rechtstreeks kennis nemen van de gedachten en gevoelens van een inheemse ingezetene van Indonesië.

Gouverneur-generaal Van Heutsz werd eind 1909 opgevolgd door A.W.F. Idenburg, een voormalig minister van koloniën. Idenburg was een overtuigd aanhanger van de 'ethische politiek' (zie pp. 114-7) en stond in beginsel positief tegenover de inheemse drang naar mondigheid.

\section{Buitenlandse stimulansen voor het Indonesische zelfbewustzijn}

De Indonesische emancipatiedrang werd ook bevorderd door ontwikkelingen in het buitenland. Vooral India oefende een voorbeeldwerking uit. Al spoedig na de opheffing van de East India Company in 1858 hadden enige inheemse Indiërs zitting gekregen in een wetgevende raad van de Britse onderkoning. In 1885 kwam door een bundeling van inheemse organisaties het Indian National Congress tot stand; twintig jaar later was dit uitgegroeid tot een nationale oppositiebeweging die vroeg om Indiaas zelfbestuur (swaraj). Intussen was deze beweging in overwegende mate een hindoe-organisatie geworden; de moslims, die een kwart van de bevolking vormden, begonnen zich zorgen te maken over hun toekomst in een door de hindoemeerderheid beheerst autonoom India en stichtten daarom een eigen massa-organisatie, de Muslim League. Het Indonesische zelfbewustzijn werd ook gestimuleerd door de in de negentiende eeuw sterk toegenomen westerse waardering voor de klassieke hindoekunst en -literatuur, waar de Indonesische cultuur veel banden mee had. Het Indiase prestige op cultureel gebied bleek verder uit de Nobelprijs die in 1913 werd toegekend aan de Indiase dichter Rabindranath Tagore.

Een andere inspiratiebron was Japan. Sinds 1868 voltrok zich daar het wonder dat het Japanse volk, na ruim twee eeuwen isolement, binnen enkele decennia leerde moderne westerse wetenschap en techniek toe te passen. Indonesische intellectuelen putten hieruit de hoop dat ook hun volk zich veel sneller zou kunnen ontwikkelen dan de Nederlanders mogelijk achtten. Het vernieuwde Japan ontpopte zich bovendien als een militaire macht van de eerste rang. Door een overwinning op China verkreeg het onder meer de heerschappij over Formosa (Taiwan). In 1905 versloeg het Rusland in Azië 
zowel op zee als op het vasteland. Dit maakte grote indruk op de inheemse bevolking van Indonesië en andere Aziatische koloniën. Voor het eerst sinds de vijftiende eeuw had een niet-westers volk een grote Europese mogendheid verslagen.

Nog op een andere manier beïnvloedde de opkomst van Japan de politieke situatie in Nederlands-Indië. Toen Nederland daar in 1899 aan de Japanners de juridische status van Europeanen toekende, lokte dit protest uit van de Chinese bevolking. De Nederlands-Indische Chinezen vormden nu een verbond om zich tegen hun achterstelling te verzetten en begonnen ook andere activiteiten ter versterking van hun positie, zoals de oprichting van eigen scholen. Die activiteiten prikkelden op hun beurt inheemse Indonesiërs tot navolging.

Intussen voltrokken zich ingrijpende veranderingen in de Filippijnen. Sinds de zeventiende eeuw had Spanje deze kolonie van Mexico uit bestuurd, totdat dit zich in 1821 van Spanje losmaakte. De Filippijnse elite, grotendeels van gemengd Spaans-Filippijnse afstamming, oriënteerde zich ook daarna meer op Latijns-Amerika dan op Azië. Al voor 1900 ontstond een Filippijnse onafhankelijkheidsbeweging, onder leiding van de dichter José Rizal. Hij werd in 1896 door de Spanjaarden terechtgesteld na het uitbreken van een opstand tegen het koloniale bewind. Een jaar eerder was ook Cuba tegen Spanje in opstand gekomen. In 1898 greep de Amerikaanse regering in beide conflicten in. De Filippijnse opstandelingen proclameerden nu een onafhankelijke republiek. Amerika dwong Spanje tot afstand van de Filippijnen, maar weigerde de republiek te erkennen. Er volgde een bijna drie jaar durende guerrilla-oorlog, die naar schatting meer slachtoffers gekost heeft dan de hele Atjeh-oorlog. Amerika wilde echter geen koloniale mogendheid zijn en ging de Filippijnen daarom voorbereiden op democratisch zelfbestuur. Het zette een grootscheeps onderwijsprogramma op. Al in 1907 kregen de Filippijnen een gekozen volksvertegenwoordiging. De uit de onafhankelijkheidsbeweging voortgekomen nationalistische partij veroverde daarin de meeste zetels. Enige jaren later begon men de Amerikaanse functionarissen zo veel mogelijk door Filippino's te vervangen.

\section{Boedi Oetomo en andere organisaties op etnische grondslag}

Leerlingen en oud-leerlingen van de artsenopleiding in Batavia (zie p. 145-6) vormden de voorhoede van de nieuwe Indonesische elite. Voorafgaand aan hun specifieke medische opleiding kregen zij een algemene vorming van hoger niveau dan die op de Kweekscholen en de Hoofdenscholen. Zij kwamen uit verschillende delen van de kolonie en behoorden meestal niet tot de hoge adel. De artsenschool STOVIA was een internaat, wat niet alleen het onderlinge contact tussen de studenten ten goede kwam maar ook contacten bevor- 
derde met Europeanen in Batavia die zich daarvoor open stelden. Daartoe behoorden de leraar Javaans D. van Hinloopen Labberton, voorman van de theosofische beweging, en de journalist E.F.E. Douwes Dekker, een achterneef van Multatuli.

Hoewel de oud-leerling Abdoel Rivai in Bintang Hindia gepleit had voor een bond van moderne inheemsen uit de hele archipel, kreeg de eerste inheemse organisatie naar westers model een meer beperkte opzet. Dit was Boedi Oetomo (Nobel Streven), een Javaanse bond ter bevordering van onderwijs en ontwikkeling. Boedi Oetomo werd op 20 mei 1908 opgericht door STOVIA-studenten samen met leerlingen van opleidingsscholen elders op Java, op initiatief van de twintigjarige student Soetomo. Ter herinnering hieraan geldt de datum van 20 mei in het huidige Indonesië als Dag van het Nationale Ontwaken.

Binnen enkele maanden telde Boedi Oetomo meer dan duizend leden, van wie studenten nu een minderheid vormden. Leden van de traditionele bestuurselite namen de leiding over en de bondszetel werd verplaatst naar Jogjakarta. De nieuwe leiding richtte de doelstellingen van de bond vrijwel alleen op zaken van onderwijs en cultuur en beperkte het lidmaatschap tot Javanen, Soendanezen en Madoerezen. Dit was een teleurstelling voor sommige jongere leden die een veel ruimere opzet beoogd hadden. Hiertoe behoorden onder meer de journalist Soewardi Soerjaningrat, die enige jaren aan de STOVIA gestudeerd had, en de arts Tjipto Mangoenkoesoemo. Tjipto had van de bond een politieke organisatie willen maken ten behoeve van de hele bevolking van Nederlands-Indië. Ook Soetomo was teleurgesteld, omdat de meeste bondsleden vooral het elite-onderwijs wilden bevorderen, terwijl hij evenals Tjipto juist het volksonderwijs voorrang wilde geven.

Het gouvernement was blij met de gematigde koers die Boedi Oetomo gekozen had en gaf de bond in 1909 officiële erkenning. Het ledental steeg tot tienduizend, maar daalde in de volgende jaren tot onder de vierduizend. De meeste leden waren ambtenaren of militairen. Ondanks zijn Javaanse opzet gebruikte de bond naast het Nederlands niet het Javaans als voertaal maar het Maleis. Van 1914 af begaf Boedi Oetomo zich ook in politieke activiteiten; van tijd tot tijd nam de bond daarbij radicale standpunten in.

Naast Boedi Oetomo kwamen verscheidene andere inheemse organisaties op etnische grondslag tot stand. Zo werd op Java al in 1908 een bond van Ambonese militairen opgericht, enkele jaren later gevolgd door een Menadonese vereniging. In 1914 vormden Soendanezen de organisatie Pasoendan, in 1917 werd een Sumatranen Bond opgericht en in 1920 een Madoerezenbond. In 1923 zag ook een organisatie voor de inheemse bevolking van Batavia het licht, de Kaoem Betawi. Bovendien ontstond er een reeks jongerenorganisaties op etnische grondslag, deels dank zij initiatieven van Javaanse, Sumatraanse, Menadonese en Ambonese STOVIA-studenten. 


\section{Vakverenigingen}

Tussen 1897 en 1907 richtten Europeanen in Nederlands-Indië de eerste vakverenigingen op. Dit waren onder meer bonden voor onderwijzers en voor personeel van de Staatsspoorwegen, van de posterijen, van landbouwondernemingen en van handelsondernemingen. De meeste van deze bonden hadden alleen Europese leden. Voorzover zij ook niet-Europeanen toelieten bleef de leiding toch in Europese handen.

Daarentegen was de in 1908 opgerichte Vereeniging van Spoor- en Tramwegpersoneel (VSTP) van begin af aan gemengd van opzet. Van 1914 af vormden de Indonesische leden er de meerderheid. In datzelfde jaar werden drie Indonesiërs in het hoofdbestuur opgenomen en werd ook een Maleis orgaan uitgegeven. In 1918 telde deze bond zesduizend leden, van wie Europeanen nog geen tiende deel uitmaakten. De VSTP had haar hoofdkantoor in Semarang.

Tussen 1911 en 1917 kwam een reeks exclusief Indonesische vakverenigingen tot stand. Eerst betrof dit vooral werknemers in intellectuele en administratieve beroepen, zoals journalisten, onderwijzers en personeel van de douane, de opiumregie, de pandhuisdienst en de openbare werken. Daarna volgden bonden van arbeiders en boeren. De belangrijkste daarvan was de in 1917 opgerichte Personeel Fabrieks Bond, die zijn aanhang voornamelijk in de suikerindustrie had.

Eind 1919 werd de eerste Indonesische vakbondsfederatie gevormd, waar al spoedig tweeëntwintig bonden met tezamen 72.000 leden aan deelnamen.

De toenemende vakbondsactiviteit droeg bij tot het ontstaan van talrijke werkstakingen, die in een aantal gevallen leidden tot loonsverhogingen en betere arbeidsvoorwaarden. In 1920 verklaarde het gouvernement dat het stakingen om uitsluitend economische redenen niet zou verhinderen, maar streng zou optreden tegen stakingen met politieke motieven. In 1923 werd de stakingsvrijheid aanzienlijk ingeperkt door de invoering van een nieuwe strafbepaling, die gevangenisstraf tot een maximum van vijf jaar stelde op het teweegbrengen van stakingen die zouden kunnen leiden tot verstoring van de openbare orde of ontwrichting van het economisch leven.

\section{De Indische Partij en het Comité Boemi Poetra}

E.F.E. Douwes Dekker, die een Javaanse grootmoeder had, stond in nauw contact met de oprichters van Boedi Oetomo maar was zelf vooral actief in organisaties van Indo-Europeanen. Hij had veel belangstelling voor de Filippijnse vrijheidsstrijd, waarin personen van Aziatisch-Europese afstamming een leidende rol speelden. Na een verblijf in Europa in 1909-1910 vestigde hij zich in 
Bandoeng en gaf daar een tijdschrift en een dagblad uit. In woord en geschrift sprak hij zich uit voor een vrij Indië als eigen vaderland voor allen die er thuishoorden, inlanders, vreemde oosterlingen en Europeanen: 'Indië voor de Indiërs!'

In september 1912 stichtte Douwes Dekker de Indische Partij, waarvoor hij tijdens een propagandareis door Java verscheidene plaatselijke afdelingen wist op te zetten. De leiding deelde hij met Tjipto Mangoenkoesoemo en Soewardi Soerjaningrat. De partij wilde volgens haar statuten alle Indiërs opwekken tot patriottisme en samenwerking op basis van staatkundige gelijkstelling om hun Indisch vaderland tot bloei te brengen en voor te bereiden voor een onafhankelijk volksbestaan. Zij keerde zich tegen rassendiscriminatie en rechtsongelijkheid en ijverde voor uitbreiding van het onderwijs en voor meer invloed op het landsbestuur. De partij telde al spoedig een zevenduizend leden, voor het merendeel Indo-Europeanen, en organiseerde manifestaties met vaandels en muziek.

De Indische Partij was de eerste echte politieke partij in de kolonie en de eerste organisatie die zich openlijk op nationale onafhankelijkheid richtte. Zij was op dat punt radicaler dan het Indian National Congress, dat nog tot 1920 uitsluitend naar zelfbestuur binnen het Britse Rijk streefde. Douwes Dekker noemde zichzelf en zijn medestanders 'nationalisten'.

De partij vroeg het gouvernement om officiële erkenning. Het gouvernement wees dit verzoek af met de motivering, dat de partij als politieke vereniging die de openbare orde bedreigde uit hoofde van het Regeringsreglement verboden was. Volgens gouverneur-generaal Idenburg betekende de doelstelling van de Indische Partij het voorbereiden van Indië voor het doorknippen van de band met Nederland en kon het Nederlands gezag zulk een doel nooit als wettig erkennen. Ook nadat de partij haar doelstelling anders geformuleerd had handhaafde Idenburg zijn afwijzing, maar hij toonde zich in maart 1913 wel bereid zijn standpunt in een uitvoerig gesprek met Douwes Dekker toe te lichten. Het bestuur ontbond daarop de partij, maar riep de leden op om over te stappen naar een al bestaande vereniging van Indo-Europeanen, Insulinde. Onder de vlag van deze vereniging werden de partij-activiteiten voortgezet. Douwes Dekker ging voor korte tijd naar Nederland om daar actie te voeren tegen de onderdrukking van de Indische Partij.

In diezelfde tijd werd in Nederlands-Indië geld ingezameld, ook bij de inheemse bevolking, voor het eeuwfeest van de Nederlandse onafhankelijkheid. Uit protest hiertegen vormde Tjipto het Inlandsch Comité tot Herdenking van Neêrlands Honderdjarige Vrijheid, naar de Maleise naam meestal aangeduid als het Comité Boemi Poetra (boemi poetra betekent inheems). Het comité vroeg om afschaffing van het verbod op politieke partijen en om instelling van een Indisch parlement. Het gaf ook een brochure uit van de hand van Soewardi onder de titel Als ik eens Nederlander was,... . Hij schreef hierin onder 


\section{SOERAT EDERAN No. 1. DJIIKA SAJA NEDERLANDER,...}

OLEH

R. M. SOEWARDI SOERJANINGRAT.

DI KELOEARKAN OLEH

Comité Boemipoetra goena merajakan Pesta Seratoes Tahoen Keradjaän Belanda. DI BANDOENG.

\section{VLUGSCHRIFT No. 1. ALS II EENS NEDERLANDEER WAS,... DOOR}

R. M. SOEWARDI SOERJANINGRAT.

UITGAVE VAN HET

Inlandsch Comité tot Herdenking van Neêrlands Honderdjarige Vrijheid. GEVESTIGD TE BANDOENG.

Druk van de Eerste Bandoengsche Publicatie Maatschappij.

Toen in 1913 in Nederlands-Indië ook onder Indonesiërs geld werd ingezameld voor het eeuwfeest van de Nederlandse onafhankelijkheid, publiceerde Soewardi

Soerjaningrat (1889-1959) deze brochure waarin hij verklaarde dat hij, als hij

Nederlander was, dit feest niet zou willen vieren in een door Nederland overheerst land. 
meer: 'Als ik Nederlander was, zou ik [...] niet willen, dat de inboorlingen dezer landen aan die herdenking mee deden [...]. Neen, voorwaar, als ik Nederlander was, ik zou nimmer zulk jubileum willen vieren hier in een door ons overheerst land. Eérst dat geknechte volk zijn vrijheid geven, dan pas onze eigen vrijheid herdenken.'

Naar aanleiding van deze brochure en enige andere publicaties arresteerde het gouvernement op basis van de exorbitante rechten (zie pp. 134-6) Soewardi en Tjipto en, na diens terugkeer, Douwes Dekker. Gesteld voor de keus tussen verbanning naar een uithoek van de archipel of vertrek uit NederlandsIndië, kozen alle drie dit laatste. Hun gedwongen vertrek uit de kolonie werd op initiatief van de Sociaal-Democratische Arbeiderspartij (SDAP) uitvoerig besproken in het Nederlandse parlement. Tjipto, die nog in 1912 een ridderorde had gekregen wegens zijn inzet voor de pestbestrijding, mocht binnen een jaar weer naar Java terugkeren. De verbanning van Soewardi werd in 1917 opgeheven, die van Douwes Dekker in 1918.

\section{De Sarekat Islam}

Dat het gouvernement de leiders van de Indische Partij uit Java verwijderde, gebeurde onder meer uit vrees voor hun mogelijke invloed op een andere beweging die in die tijd opkwam. Dit was de Sarekat Islam (SI, Islam-Bond), een organisatie voor samenwerking tussen moslims, die in 1912 was voortgekomen uit een al bestaande islamitische handelsbond op initatief van een batikhandelaar in Solo. De leiding kwam al spoedig in handen van een bondslid in Soerabaja, Oemar Said Tjokroaminoto. Hij behoorde tot een regentenfamilie en had gestudeerd op een OSVIA (ambtenarenschool, zie p. 145), maar wilde geen loopbaan bij de overheid en werkte onder meer als journalist.

Tjokroaminoto toonde zich een geboren organisator en volksmenner, die zijn toehoorders zelfvertrouwen en strijdbaarheid wist in te boezemen. Zijn optreden leidde tot de vorming van een groot aantal afdelingen van de nieuwe bond. Moslimvoorgangers in de dorpen werkten aan deze snelle uitbreiding mee. Begin 1913 had de SI al honderdduizend leden, ruim een jaar later waren het er meer dan driehonderdduizend. De eerste congressen van de bond, in 1913 in Soerabaja en Solo in de open lucht gehouden, trokken vele duizenden deelnemers. De stormachtige groei van de organisatie bewees, dat emancipatieverlangens niet alleen bij een handvol ontwikkelde inheemsen leefden maar ook onder brede lagen van de inheemse bevolking. Dat die zich juist op grondslag van de islam verenigden, kwam vooral omdat het onderscheid tussen de koloniale overheersers en de overheersten voor een groot deel van de bevolking samenviel met dat tussen christenen en moslims.

Uiteraard werden de bestuursfuncties vooral door ontwikkelden ver- 
vuld. Zo was Soewardi Soerjaningrat begin 1913 voorzitter van de afdeling Bandoeng van de SI. Vice-voorzitter van die afdeling was de journalist Abdoel Moeis. Deze was afkomstig uit Minangkabau, had enige jaren aan de STOVIA gestudeerd en was daarna assistent van Abendanon geweest. Moeis was in 1913 bovendien lid van het Comité Boemi Poetra. In 1916 werd hij vice-voorzitter van het centrale SI-bestuur.

De Sarekat Islam was de eerste Indonesische massabeweging. De beweging bleef bovendien niet tot Java beperkt, maar kreeg ook grote aanhang daarbuiten, vooral op Sumatra en Borneo. Op haar hoogtepunt in 1916 had zij ongeveer een half miljoen leden. De SI was echter geen strak geleide organisatie, maar eerder een losse verzameling plaatselijke bonden, die veel verschillen in opvattingen en in optreden aan de dag legden. Sommige begaven zich in antiChinese agitatie, andere richtten scholen en coöperaties op en legden klachten uit de bevolking voor aan het Binnenlands Bestuur.

Een deel van de aanhang beschouwde de Sarekat Islam als een instrument voor lotsverbetering binnen het bestaande koloniale bestel. Een aanzienlijk deel van de Javaanse leden bleek echter veel verder reikende verwachtingen te hebben: zij zagen in Tjokroaminoto de lang verwachte ratoe adil, die een eind zou maken aan onrecht en vreemde overheersing (zie pp. 56-7). De leiding van de SI was zich ervan bewust dat een confrontatiekoers tegenover het koloniale gezag het gevaar meebracht door het gouvernement te worden uitgeschakeld, zoals met de leiders van de Indische Partij gebeurde. Tjokroaminoto verklaarde in zijn openbare uitspraken, dat de SI niet op revolutie uit was maar graag met het gouvernement wilde samenwerken.

Ook het moslimkarakter van de SI had niet voor allen dezelfde betekenis. Voor sommigen betekende het vooral dat men zich verenigde tegenover de Nederlanders en de Chinezen; voor anderen was bevordering van de islam wel degelijk een belangrijke doelstelling. De islamitische grondslag van de SI had overigens tot gevolg dat verscheidene Arabische handelaren de bond financieel ondersteunden.

De SI had al in september 1912 officiële erkenning aangevraagd. Gouverneur-generaal Idenburg, die in de geest van de ethische politiek de inheemse emancipatie positief tegemoet wilde treden, zag zich hierdoor voor een dilemma geplaatst. Hij besprak de kwestie in maart 1913 met de leiding van de SI. Uiteindelijk wees hij de aanvraag af, maar verklaarde hij zich niettemin bereid erkenning van plaatselijke en regionale SI-bonden te overwegen. Inderdaad kregen daarna ruim vijftig van die bonden rechtspersoonlijkheid. In 1915 sloten ze zich aan bij een nieuwe koepelorganisatie, Centraal Sarekat Islam, met zetel in Soerabaja. Een jaar later werd deze organisatie toch door het gouvernement erkend. Idenburg's welwillende opstelling wekte overigens grote verontwaardiging bij veel Nederlanders; zij vonden van begin af aan dat de Sarekat Islam verboden moest worden. 
De alsnog erkende nationale Sarekat Islam hield in 1916 in Bandoeng een nieuw congres. De bond had intussen als één van zijn symbolen een roodwitte vlag ingevoerd omdat, naar men zei, dit eens de kleuren van Modjopahit geweest waren. Tjokroaminoto beklemtoonde op het congres de noodzaak van inheemse medezeggenschap in het koloniale bestuur, maar gaf opnieuw blijk van een coöperatieve houding tegenover het gouvernement.

Na 1916 nam de Sarekat Islam geleidelijk een meer militante houding tegenover het koloniale gezag aan, deels door de toenemende invloed van een marxistische stroming binnen en buiten de bond.

\section{Sneevliet en de Indische Sociaal-Democratische Vereeniging}

Het ontstaan van een marxistische stroming in de Indonesische politiek was grotendeels het werk van Henk Sneevliet, een socialistische activist die in maart 1913 in Nederlands-Indië kwam. In Europa was toen binnen de socialistische beweging al jaren een richtingenstrijd aan de gang tussen de reformistische rechtervleugel, die de maatschappij in hoofdzaak langs parlementaire weg wilde hervormen, en de radicale linkervleugel, die in massa-actie en eventueel revolutionaire actie het belangrijkste middel zag om een nieuwe maatschappij tot stand te brengen. Sneevliet was in Nederland bezoldigd voorzitter geweest van de vakbond voor spoor- en tramwegpersoneel, maar had die positie verloren als gevolg van zijn radicale opstelling. Daarna was hij naar Indië vertrokken, waar hij korte tijd journalist was in Soerabaja en vervolgens secretaris werd van de Handelsvereeniging in Semarang.

Sneevliet had zijn politieke belangstelling niet verloren. Al in de eerste maanden van zijn verblijf sprak hij zowel met Tjokroaminoto als met Douwes Dekker. Zelf vond hij noch de islam noch de Indische natie een juiste grondslag voor de strijd tegen het kolonialisme, omdat hij dit bovenal als een verschijningsvorm van het kapitalistische stelsel zag. In zijn visie moest men het kolonialisme bestrijden in het kader van de internationale klassenstrijd tegen alle vormen van kapitalisme. Sneevliet onderhield van begin af aan goede contacten met Indonesiërs en wist zijn politieke visie op verscheidenen van hen over te brengen. Ook verwierf hij een behoorlijke kennis van het Maleis en het Javaans. Ter bevordering van zijn politieke doeleinden maakte hij graag gebruik van bestaande organisaties.

De eerste organisatie die zich daartoe leende was de in Semarang zetelende Vereeniging van Spoor- en Tramwegpersoneel, die veel waarde aan zijn oordeel hechtte op grond van zijn vroegere functie. Sneevliet kwam in de redactie van het bondsorgaan. Onder zijn invloed werd de VSTP steeds militanter en nam haar inheemse aanhang sterk toe.

Een tweede mogelijkheid bood de Indische Sociaal-Democratische Vereeni- 
ging (ISDV) die in mei 1914 op initiatief van Sneevliet werd opgericht door dertig Nederlandse socialisten. In de eerstvolgende jaren kreeg deze vereniging er nog ruim honderd leden bij kreeg, onder wie ook enige Indonesiërs. Onder de oprichters vormden de radicalen een kleine minderheid, maar Sneevliet zat wel in het bestuur. Anderhalf jaar later richtte hij een nauw met de ISDV verbonden tijdschrift op. Geleidelijk wisten de radicalen hun invloed in de vereniging te versterken.

In de derde plaats werkte Sneevliet samen met de vereniging Insulinde, die het nationalistische streven van de Indische Partij voortzette en haar hoofdzetel in Semarang had. Tjipto Mangoenkoesoemo kwam na zijn terugkeer uit ballingschap in de leiding daarvan, maar de aanhang bestond nog steeds voornamelijk uit Indo-Europeanen.

Om de Indonesische massa's zelf te bereiken was het van belang invloed te krijgen binnen de Sarekat Islam. Dit gebeurde in hoofdzaak door de Javaanse spoorwegbeambte Semaoen, Sneevliet's meest begaafde discipel, die al op jeugdige leeftijd in de VSTP, de SI en de ISDV actief was. Semaoen werd in 1917 voorzitter van de afdeling Semarang van de SI en spande zich vervolgens in om de hele SI in marxistische zin te beïnvloeden. In de volgende jaren werd hij bovendien lid van de gemeenteraad van Semarang en voorzitter van de VSTP.

Sneevliet richtte in 1915 een actiecomité tegen de haatzaai-artikelen op (zie p. 136-7), waaraan onder meer de Inlandsche Journalisten Bond, de VSTP, de ISDV en Insulinde deelnamen. In 1916 trad hij uit de Nederlandse SDAP en werd hij lid van de Nederlandse Sociaal-Democratische Partij (SDP). Deze partij, die op het punt van koloniaal beleid de leuze 'Indië los van Holland' uitdroeg, doopte zich twee jaar later om tot Communistische Partij.

In maart 1917 reageerde Sneevliet geestdriftig op de Russische revolutie die het tsarenregime ten val had gebracht. In een dagbladartikel stelde hij die revolutie ten voorbeeld aan het volk van Java. Dit leidde tot een strafvervolging en tot zijn ontslag als secretaris van de Handelsvereeniging. Het strafproces vond in november plaats. Sneevliet klaagde het kolonialisme aan in een drie dagen durende verdedigingsrede en kreeg uiteindelijk ontslag van rechtsvervolging. Intussen hadden de reformistische leden van de ISDV hun lidmaatschap opgezegd en een Nederlands-Indische afdeling van de SDAP gesticht, die zich later Indische Sociaal-Democratische Partij (ISDP) noemde. De ISDV werd nu voorgoed een radicaal-marxistisch bolwerk.

Een jaar later spoorde Sneevliet de inheemse militairen van leger en vloot tot dienstweigering aan. Voor het gouvernement was nu de maat vol; het wees hem uit op grond van de exorbitante rechten. Eind 1918 moest Sneevliet de kolonie verlaten. Later verwijderde het gouvernement nog andere Nederlandse radicalen uit Indonesië, waardoor de leiding van de ISDV meer en meer bij Indonesiërs kwam te berusten. In 1920 veranderde de vereniging haar naam in 
Perserikatan Kommunist di India (PKI, Communistische Vereniging in Indië). Voorzitter hiervan werd Semaoen; vice-voorzitter werd Darsono, een andere leerling van Sneevliet.

\section{De Politieke Inlichtingen Dienst}

In 1916 richtte het gouvernement een Politieke Inlichtingendienst (PID) op, voornamelijk om toezicht uit te oefenen op binnenlandse politieke bewegingen. Na drie jaar hief men deze dienst weer op, maar zijn feitelijke werkzaamheden werden al spoedig in andere organisatorische kaders hervat en op de duur zelfs aanzienlijk uitgebreid. Dit werk gebeurde gedeeltelijk op centraal niveau, gedeeltelijk op regionaal en plaatselijk niveau, bijvoorbeeld door speciale afdelingen van de stedelijke politie. Hoewel er sinds 1919 geen centraal orgaan met de naam PID meer bestond, bleef men deze naam algemeen gebruiken voor alle delen van het politieapparaat die zich met toezicht op politieke activiteiten bezighielden. Dit spraakgebruik beantwoordde in zo verre aan de feitelijke situatie, dat het toezicht dat deze verschillende organen uitoefenden inderdaad van een centraal punt uit geleid werd. Daarom zal dit spraakgebruik ook hier gevolgd worden.

Op landelijk en plaatselijk niveau controleerden de PID-organen het doen en laten van alle politieke personen en groeperingen die naar hun mening een bedreiging voor het gevestigd gezag konden opleveren. Daarbij maakten deze organen gebruik van open bronnen en van in het geheim verkregen informatie. Zij volgden de pers, zowel om inlichtingen te verzamelen als om eventuele persdelicten te signaleren. $\mathrm{Zij}$ waakten tegen de invoer van politiek ongewenst drukwerk uit het buitenland. Zij controleerden of het onderwijs op particuliere scholen geen politieke propaganda bevatte. Zij adviseerden het plaatselijk bestuur bij beslissingen over het toestaan van politieke vergaderingen. Ook namen zij deel aan huiszoekingen, arrestaties en verhoren.

De centrale PID-organen verwerkten de van alle kanten binnenkomende informatie. Zij lichtten de top van het gouvernement voor over de lopende politieke ontwikkelingen. Ook leverden zij gegevens ten behoeve van concrete beslissingen, bijvoorbeeld over strafvervolgingen en verbanningen.

Het voor het publiek meest zichtbare deel van het PID-werk was de uitoefening van toezicht bij openbare vergaderingen. Radicale en nationalistische sprekers werden vaak onderbroken door de altijd aanwezige PID-agenten, die dan tegen bepaalde termen bezwaar maakten. Herhaaldelijk werden vergaderingen door zulke agenten voortijdig ontbonden.

De PID beschikte over een uitgebreid netwerk van informanten. Daartoe behoorden ook personen die zelf actief waren binnen de door de PID gewantrouwde organisaties en soms zelfs in de leiding daarvan. 


\section{De Indië Weerbaar-campagne}

Al sinds het begin van de twintigste eeuw verschilden Nederlandse deskundigen van mening over de vraag hoe men Nederlands-Indië kon verdedigen tegen een van buiten komende aanval (waarbij vooral aan Japan werd gedacht). Het koloniale leger, bestaande uit ongeveer tienduizend Europese en ongeveer vijfentwintigduizend inheemse beroepsmilitairen en vrijwilligers, was noch uitgerust noch opgeleid voor oorlogvoering tegen een modern bewapende buitenlandse vijand. Als dit leger met de externe verdediging van de kolonie werd belast, zou het in ieder geval sterk moeten worden uitgebreid. Die uitbreiding zou onvermijdelijk leiden tot een groter inheems aandeel in de troepenmacht, omdat het Nederlandse volk te klein was om zelf de benodigde mankracht te leveren en bovendien Europese militairen aanzienlijk duurder waren dan inheemse. Om de kosten te beperken zou het verder nuttig zijn, naast de werving van vrijwilligers ook dienstplicht voor inheemsen in te voeren.

Tegen zo'n uitbreiding van de koloniale landmacht bestonden behalve financiële ook politieke bezwaren. Het kon riskant zijn om een overheerste bevolking de beschikking te geven over een grote militaire macht. Zo had de Indian Mutiny van 1857 bijna een eind gemaakt aan de Britse heerschappij in India. Het risico zou nog groter worden als die macht zich in handen van dienstplichtigen zou bevinden, wier loyaliteit jegens de koloniale overheersers vermoedelijk zou onderdoen voor die van vrijwilligers. Aan de andere kant meenden sommige aanhangers van de ethische politiek, dat invoering van inheemse dienstplicht juist blijk zou geven van Nederlands vertrouwen en daardoor de band met de inheemse bevolking zou versterken.

Tegenover de pleitbezorgers van een sterkere landmacht stonden de voorstanders van een sterkere zeemacht. Aangezien het om een archipel ging, zou een externe aanval alleen over zee kunnen plaatsvinden. Daarom was het beter zulk een aanval al op zee af te slaan, maar daartoe zou men over een veel sterkere marine moeten beschikken. Japan had zelf in 1905 het belang van een sterke marine gedemonstreerd door zijn overwinning op de Russische vloot. De Nederlandse regering koos in 1913 weloverwogen voor een maritieme verdedigingsstrategie: de marine zou moeten zorgen voor de externe verdediging van de archipel, terwijl handhaving van de interne rust en orde de hoofdtaak van het koloniale leger zou blijven. In dat verband zou dit leger eerder in aanmerking komen voor inkrimping dan voor uitbreiding, in het bijzonder nu de afronding van het koloniale rijk voltooid was.

Na het uitbreken van de Wereldoorlog in 1914 mobiliseerde Nederland in drie dagen een landmacht van ruim tweehonderdduizend man. Voorstanders van uitbreiding van het koloniale leger brachten nu in Nederlands-Indië een discussie over de externe verdediging op gang, waarbij sommigen in het bijzonder pleitten voor versterking van het leger met een uit inheemse dienst- 
plichtigen te vormen Inlandse militie. Voor dit denkbeeld, dat gesteund werd door gouvernementsambtenaren en oud-gouverneur-generaal Van Heutsz, werd ook geprobeerd Indonesische steun te verkrijgen. De discussie groeide daardoor uit tot een verhitte controverse, waar zowel Indonesiërs als Nederlanders aan deelnamen en die tot het eind van de oorlog is voortgezet. In beide bevolkingsgroepen waren de meningen zeer verdeeld. Weliswaar voelden veel Nederlanders wel voor de invoering van een Inlandse militie, maar de ISDV was daar fel tegen, evenals de vereniging Insulinde. De leiding van Boedi Oetomo wilde het militie-idee steunen, maar moest haar steun op wens van de leden afhankelijk stellen van politieke concessies. Voor het eerst ging Boedi Oetomo nu een politieke rol spelen. Bij de Sarekat Islam keerden verscheidene afdelingen, waaronder die van Semarang en Batavia, zich tegen een Inlandse militie. Daarentegen zag Abdoel Moeis het militieplan als een nuttige hefboom voor politieke veranderingen. Met moeite lukte het hem het centrale SI-bestuur hierin mee te krijgen.

De voorstanders organiseerden in 1916 een grote campagne onder de leuze 'Indië Weerbaar'. De leiding berustte bij een Comité Indië Weerbaar, dat besloot een deputatie naar Nederland te sturen om een motie aan te bieden aan koningin en regering. De motie, die werd aangenomen op door Indië Weerbaar belegde massabijeenkomsten, sprak in algemene termen over de noodzaak van betere weerbaarheid en ging niet op de kwestie van een Inlandse militie in, wegens de bezwaren binnen de Sarekat Islam. Bovendien kreeg de campagne ook steun van voorstanders van een sterkere marine. Van Hinloopen Labberton leidde de deputatie, die verder bestond uit een IndoEuropese legerofficier en vijf vertegenwoordigers van Indonesische organisaties. De SI gaf haar vertegenwoordiger, Abdoel Moeis, een uitvoerige politieke instructie mee. De deputatie arriveerde in maart 1917 in Nederland, waar zij enige maanden bleef en met veel égards behandeld werd. Zij werd ontvangen door koningin Wilhelmina en had ontmoetingen met ministers en parlementsleden. Individuele leden van de deputatie gaven interviews en hielden spreekbeurten. Daarbij spraken de vertegenwoordigers van Boedi Oetomo en Sarekat Islam zich uit voor de instelling van een echt Indisch parlement met wetgevende macht; alleen zulk een parlement zou mogen besluiten tot de invoering van een Inlandse militie. Moeis verklaarde verder dat de SI zich wilde voorbereiden op een zelfstandig Indië.

De deputatie had slechts weinig invloed op de in Nederland heersende opvattingen. Regering en parlement bleven de externe verdediging van Nederlands-Indië als een marinetaak zien. Wel voerde de regering daar in 1917 dienstplicht voor Nederlanders in en kwam zij in 1918 met plannen voor een Inlandse militie van honderdduizend man, maar deze plannen werden enkele jaren later weer ingetrokken. Ook waren regering en parlement niet bereid wetgevende macht te geven aan een Nederlands-Indische volksvertegenwoordiging. 


\section{Instelling van de Volksraad}

Eind 1916, enige maanden voordat de deputatie van Indië Weerbaar in Nederland kwam, had het Nederlandse parlement een wet aangenomen tot instelling van een nieuw orgaan voor Nederlands-Indië, de Volksraad. Hierin zouden representatief geachte inwoners van de kolonie in het openbaar kunnen meepraten over wetgeving en beleid. Aan deze wet waren jarenlange discussies voorafgegaan, die hun oorsprong vonden in de al voor 1900 opgekomen onvrede onder de in Indonesië werkende Nederlanders over hun volledig gemis aan zeggenschap over het bestuur. Hoewel de nadien in het kader van de decentralisatie ingestelde plaatselijke en regionale raden deze onvrede ten dele hadden kunnen wegnemen, was besloten ook een vertegenwoordigend lichaam voor de hele kolonie in het leven te roepen. Naast Nederlanders zouden ook andere Nederlandse onderdanen (Indonesiërs, Chinezen en Arabieren) daar zitting in kunnen hebben.

Volgens de wet van 1916 kreeg deze Volksraad alleen adviserende bevoegdheden en ook zijn representativiteit was beperkt. Een aanzienlijk deel van de leden zou van bovenaf worden benoemd; de overige leden zouden worden gekozen door de leden van de plaatselijke en regionale raden. De zetelverdeling tussen de verschillende bevolkingsgroepen werd van te voren vastgelegd. De regering besloot dat de Raad uit 39 personen zou bestaan, onder wie 15 Indonesiërs. De regering zou zelf de voorzitter benoemen; van de gewone leden zou de helft worden gekozen en zou de andere helft door de gouverneur-generaal worden benoemd. Deze zou zijn benoemingen ná de verkiezing moeten doen, zodat hij de verkiezingsuitslag nog kon corrigeren als die te weinig recht had gedaan aan bepaalde politieke stromingen, maatschappelijke belangen of delen van de archipel.

De aldus door Nederland vastgestelde opzet van de Volksraad stelde veel politiek bewuste Indonesiërs teleur. Boedi Oetomo, de Sarekat Islam en enige andere verenigingen publiceerden medio 1917 een gezamenlijk politiek program, waarin zij verklaarden te streven naar een 'parlementaire regeringsvorm in nationale geest' en naar gelijkheid en uniformiteit van recht. Niettemin waren ze bereid aan de Volksraad mee te werken. Ten eerste betekende die in elk geval een grote stap vooruit ten opzichte van het bestaande volstrekt autocratische bestel. Ten tweede had de regering zelf verklaard te verwachten dat de Volksraad in de toekomst wetgevende bevoegdheid zou kunnen krijgen. Bovendien was er vertrouwen in de in 1916 aangetreden gouverneur-generaal J.P. van Limburg Stirum, die de benoemingen zou moeten verrichten. Hij was diplomaat van beroep en had geen Indische achtergrond, maar was evenals zijn voorganger Idenburg een overtuigd voorstander van de ethische politiek.

Tot de gekozen leden van de eerste Volksraad behoorden onder meer 
de Indonesiërs Abdoel Rivai, Abdoel Moeis en Koesoemo Joedo en de Nederlanders Bosscha en Van Hinloopen Labberton. Daarnaast benoemde Van Limburg Stirum onder meer Tjokroaminoto, Tjipto Mangoenkoesoemo en de voorzitter van de Indische Sociaal-Democratische Partij, ir. Ch.G. Cramer. Hij installeerde de Raad op 18 mei 1918. Tot zijn teleurstelling had koningin Wilhelmina het niet nodig gevonden een boodschap tot dit nieuwe orgaan te richten.

De leden van de Volksraad werden voor een tijdvak van drie jaar gekozen of benoemd. De Raad kwam tweemaal per jaar een paar maanden bijeen en vergaderde in beginsel in het openbaar. Hoge ambtenaren traden in de vergaderingen op als gemachtigden van het gouvernement om het beleid toe te lichten en te verdedigen. De leden konden niet strafrechtelijk vervolgd worden voor wat zij in de Raad zeiden of schriftelijk aan de Raad voorlegden.

Hoewel de Volksraad tot 1927 uitsluitend een adviesorgaan was, was hij juist in de eerste jaren het toneel van openhartige discussies en scherpe kritiek. Het gouvernement was onder meer verplicht de Raad te raadplegen over de begroting. Dit gaf de Raadsleden op zichzelf al gelegenheid om het hele beleid en allerlei facetten daarvan te bespreken. In de tweede plaats vroeg zowel de Nederlandse regering als het Nederlands-Indische gouvernement de mening van de Volksraad over verschillende voornemens tot wetgeving. Zo wijdde de Raad in 1918 en 1919 uitvoerige besprekingen aan het plan van de regering voor een Inlandse militie. Verder nam de Raad tientallen moties aan en behandelde hij honderden uit de bevolking binnengekomen klachten en verzoekschriften. Ook stelden de leden tal van schriftelijke vragen, die dan samen met de antwoorden gepubliceerd werden.

De Volksraad werd in 1921 uitgebreid tot 49 leden, onder wie 20 Indonesiërs, waarbij de gewone leden wederom voor de helft werden gekozen en voor de helft werden benoemd.

In 1927 kreeg de Volksraad bevoegdheden die verder gingen dan adviesverlening. Tegelijk werd het aantal leden uitgebreid tot 61 en de zittingsduur tot vier jaar, terwijl bovendien het kiesstelsel verandering onderging.

\section{Uitzicht op geleidelijke dekolonisatie}

In de jaren waarin de Volksraad voor Nederlands-Indië werd voorbereid, maakten de Filippijnen aanzienlijk méér voortgang in de richting van dekolonisatie. Al sinds 1907 beschikten ze over een gekozen volksvertegenwoordiging. In 1914 kregen Filippino's de meerderheid in het kabinet van de gouverneur. In 1916 gingen de Verenigde Staten een grote stap verder met de Philippine Autonomy Act. Deze wet gaf de Filippijnen een volledig parlement, bestaande uit een Assemblee en een Senaat, te kiezen op basis van algemeen 
kiesrecht voor allen die Engels, Spaans of een Filippijnse taal konden lezen en schrijven. Nog belangrijker was de preambule van de wet, die verklaarde dat de Verenigde Staten de onafhankelijkheid van de Filippijnen zouden erkennen zodra daar een stabiele regering gevestigd kon worden.

De Britse regering ging ten aanzien van India minder ver. Niettemin gaf zij de inheemse bevolking na 1907 ook daar meer medezeggenschap. Een Indiër werd opgenomen in de uitvoerende raad van de onderkoning (te vergelijken met de Raad van Indië). Daarnaast kreeg de inheemse bevolking meer zetels in de centrale wetgevende raad en in de provinciale en plaatselijke raden. Voormannen van de Congrespartij spraken nu in de wetgevende raad mee over de begroting. Wat de toekomst betreft deed de Britse regering in augustus 1917 toezeggingen waaruit viel af te leiden, dat India eens als deel van het Britse Rijk een zichzelf besturend gebied zou kunnen worden, waarvan de regering verantwoordelijk zou zijn aan een eigen parlement.

Kort daarna ging de Nederlandse regering ten aanzien van NederlandsIndië een eind in dezelfde richting. In maart 1918 verklaarde zij zich ten doel te stellen 'Indië's hulpbronnen zooveel mogelijk door Indische volkskracht te ontsluiten, de bevolking geschikt te maken tot het behartigen van eigen belangen en het bestuur van eigen land en daarmede de grondslag te leggen voor een volledig zelfbestuur'. Onder politiek bewuste Indonesiërs nam de ontevredenheid over het koloniaal bestel niettemin toe. In de eerste zitting van de Volksraad in mei-juli 1918 leverden de Indonesische leden zulke felle kritiek dat veel Nederlanders er diep door geschokt werden. Een eind september bijeengekomen congres van de Sarekat Islam getuigde eveneens van ontstemming en ongeduld. Op voorstel van Tjokroaminoto sprak het congres zich onder meer uit voor spoedige invoering van volledig zelfbestuur, kiesrecht voor alle mannen die schrijven konden en evenredige vertegenwoordiging van alle bevolkingsgroepen in de Volksraad (wat dus een overweldigende Indonesische meerderheid zou meebrengen). Hetzelfde congres koos de marxist Semaoen in het hoofdbestuur.

Op 11 november 1918 kwam er een eind aan de Wereldoorlog. De politieke spanning in Nederlands-Indië steeg door berichten over revoluties in verschillende delen van de wereld. In de weer bijeengekomen Volksraad deelde ir. Cramer nu mee, dat de Raadsleden van de ISDP, de Sarekat Islam, Boedi Oetomo en Insulinde een gezamenlijk urgentieprogram van hervormingen zouden opstellen. Zij noemden hun samenwerkingsverband de Radicale Concentratie en streefden naar de vorming van een uit en door het volk gekozen parlement en de instelling van een aan dat parlement verantwoordelijke regering.

In deze situatie vond gouverneur-generaal Van Limburg Stirum het nodig onverwijld uitzicht op fundamentele veranderingen te bieden om de spanning te verminderen. Hij liet zijn woordvoerder in de Volksraad daarom op 18 
november en 2 december verklaringen voorlezen, waarin onder meer sprake was van een door de jongste wereldgebeurtenissen voorgeschreven nieuwe koers en van een in de toekomst noodzakelijke aanzienlijke uitbreiding van de bevoegdheden van de Volksraad, die dan daadwerkelijke medezeggenschap in en controle op het bestuur zou moeten krijgen. Verder kondigde hij de instelling van een commissie aan die een advies zou moeten opstellen over herziening van de staatsinrichting van Nederlands-Indië.

Deze verklaringen van gouverneur-generaal Van Limburg Stirum zijn bekend komen te staan als de 'november-beloften'. Noch de tekst van zijn verklaringen noch zijn plan voor een herzieningscommissie had hij van te voren aan de Nederlandse regering voorgelegd.

De enige weken later ingestelde commissie telde zesentwintig leden, onder wie acht Indonesiërs, en werd geleid door prof.dr. J.H. Carpentier Alting, president van het Hooggerechtshof. Hoewel de meningen onder de leden sterk uiteenliepen, kon de commissie medio 1920 een veelomvattend rapport uitbrengen met voorstellen waar een meerderheid mee instemde.

De commissie stelde onder meer voor ieder wettelijke onderscheid naar ras en landaard af te schaffen. Indonesiërs zouden toegang moeten krijgen tot alle functies in het Binnenlands Bestuur. De Volksraad zou moeten worden vervangen door een vertegenwoordigend lichaam van minstens honderd leden, onder wie tachtig gekozen leden. Deze volksvertegenwoordigers zouden niet via getrapte verkiezingen maar rechtstreeks gekozen moeten worden, met kiesrecht voor alle onderdanen met een bepaald minimum-inkomen die konden lezen en schrijven. De regering zou bestaan uit de gouverneur-generaal plus de Raad van Indië en zou in beginsel de wetgevende macht samen met de volksvertegenwoordiging uitoefenen. De commissie wilde het bestaande Regeringsreglement vervangen door een geheel nieuwe wet en legde daartoe een ontwerp voor. Zij stelde ook een verandering voor van de staatsrechtelijke verhouding tussen Nederlands-Indië en Nederland en ontwierp daartoe wijzigingen van de Nederlandse grondwet. Onder meer wilde zij de naam 'Nederlands-Indië' veranderd zien in 'Indië', om aan te geven dat dit Rijksdeel niet aan Nederland ondergeschikt was.

Intussen had het Britse parlement eind 1919 een nieuwe Government of India Act aangenomen, die ter uitvoering van de toezeggingen van 1917 de invloed van de inheemse bevolking op het bestuur aanzienlijk vergrootte. Het ledental van de centrale wetgevende raad en van de provinciale raden werd uitgebreid; de meerderheid van die leden zou voortaan niet meer worden benoemd maar gekozen, op basis van kiesrecht voor allen die aan bepaalde criteria van ontwikkeling en welstand voldeden. Het bestuur over de provincies zou gedeeltelijk worden uitgeoefend door Indiase ministers, die verantwoording verschuldigd zouden zijn aan de provinciale raden. Drie Indiërs werden opgenomen in de uitvoerende raad van de onderkoning. 
De Nederlandse regering diende in 1921 bij het parlement enige ontwerpwijzigingen van de grondwet in, die gedeeltelijk aan de voorstellen van de commissie-Carpentier Alting ontleend waren. In de toelichting op haar grondwetsvoorstellen schreef de regering onder meer, dat 'zoowel wetgeving als bestuur ten aanzien van de inwendige aangelegenheden zooveel mogelijk moeten worden gelegd in handen van in Indië zelf zetelende lichamen en overheden en dat aan de aldaar gevestigde bevolking een zoo groot mogelijke invloed op en aandeel in de samenstelling dier lichamen moet worden toegekend'. Zij handhaafde overigens de naam 'Nederlands-Indië'. Daarentegen besloot de Tweede Kamer op aandrang van de Volksraad het woord 'kolonie' uit de grondwet te verwijderen. In 1922 werd de gewijzigde grondwet van kracht. Terwijl artikel 1 vroeger luidde: 'Het Koninkrijk der Nederlanden omvat het grondgebied in Europa, benevens de koloniën en bezittingen in andere werelddeelen', kwam het nu te luiden: 'Het Koninkrijk der Nederlanden omvat het grondgebied van Nederland, NederlandschIndië, Suriname en Curaçao'. Van nog meer belang was een geheel nieuw artikel, dat bepaalde dat de regeling van de inwendige aangelegenheden van Nederlands-Indië in beginsel werd overgelaten aan aldaar gevestigde organen, terwijl in die gevallen waarin de Nederlandse wetgever onderwerpen betreffende dat gebied zou regelen, het vertegenwoordigend lichaam van het gebied gehoord zou moeten worden.

Uit de grondwetswijziging van 1922 leidden sommige Indonesiërs af, dat Nederland serieus bereid was aan de koloniale verhouding een eind te maken.

Studenten in Nederland; de Indische Vereeniging en het Indonesisch Verbond van Studeerenden

Sinds het eind van de negentiende eeuw kwamen Indonesiërs op beperkte schaal naar Nederland om te studeren aan universiteiten en andere onderwijsinstellingen. In 1900 waren het pas enkelen, maar hun aantal nam toe tot bijna veertig in 1910, ongeveer zeventig in 1920 en een maximum van honderdvijftig in 1930. In gelijksoortige omvang studeerden ook Chinezen uit Indonesië in Nederland. De Indonesische studerenden richtten in 1908 de Indische Vereeniging (IV) op, met Abendanon als erelid. De Chinese studenten hadden een eigen vereniging, de Chung Hwa Hui.

In de beginjaren hield de IV zich nauwelijks met politiek bezig. Eén van haar voorzitters in die tijd was Hoesein Djajadiningrat, een regentenzoon uit Bantam die op aansporing van Snouck Hurgronje in Leiden oosterse talen studeerde en daarna als eerste Indonesiër aan een Nederlandse universiteit promoveerde. Van 1911 tot 1914 berustte het voorzitterschap bij een andere 
aristocraat, Noto Soeroto, die meende dat de emancipatie van Indonesië nog een langdurig samengaan met Nederland vereiste. Hij beijverde zich om het Nederlandse volk bekend te maken met de Javaanse cultuur, schreef gedichten in het Nederlands, werd opgenomen in de Nederlandse kring van schrijvers en kunstenaars en bleef tot 1932 in Nederland.

Na 1912 nam de politieke bewustwording onder de Indonesische studenten sterk toe, ten dele onder invloed van de ontwikkelingen in hun geboorteland. Zo schreef G.S.S.J. Ratoelangie, een christen uit de Minahasa, een brochure over de Sarekat Islam, waarin hij zowel het Nederlandse bestuur als de inheemse adel scherp bekritiseerde. Eind 1914 werd hij voorzitter van de IV. De meest gezaghebbende figuur onder de Indonesiërs in Nederland was in deze periode de vroegere voorman van de Indische Partij, Soewardi Soerjaningrat. Hij was eind 1913 als balling aangekomen en volgde een Nederlandse onderwijzersopleiding. Nadat zijn verbanning was opgeheven, bleef hij nog tot 1919 in Nederland, omdat de regering lange tijd weigerde zijn terugreis te betalen. Soewardi was een principieel voorstander van onafhankelijkheid voor Indonesië, al hoopte hij evenals Ratoelangie dat de scheiding met Nederland zich in vriendschap zou voltrekken. Hij werd lid van de SDAP en probeerde vergeefs deze partij tot het standpunt 'Indië los van Holland' te bekeren. Hij keerde zich tegen de Indië Weerbaar-campagne en pleitte voor de instelling van een Indisch parlement met wetgevende macht. Hij publiceerde veel en redigeerde onder meer het door de IV uitgegeven maandblad Hindia Poetra (Zonen van Indië).

Intussen leidde de politieke bewustwording tot enig onbehagen over het woord Indië ter aanduiding van de Indische archipel. Men gebruikte de naam Indië immers ook voor delen van het Aziatische vasteland, zoals Voor-Indië en Achter-Indië, terwijl de nadere aanduiding Nederlands-Indië onverbrekelijk met de koloniale overheersing verbonden was. Er bestond daarom behoefte aan een andere naam, die ook na het eind van die overheersing in stand zou kunnen blijven. Bovendien waren er problemen met het woord Indiër. Behalve dat dit ook voor de inheemse bevolking van Voor-Indië gebruikt werd, deed zich hier nog een andere complicatie voor. Ter vermijding van de officiële term Inlanders, die een beledigende klank gekregen had, hadden de oprichters van de Indische Vereniging de inheemse bevolking van Nederlands-Indië als Indiërs betiteld. Maar daarna waren de Indische Partij en de Vereniging Insulinde dezelfde benaming uitdrukkelijk gaan gebruiken voor de hele bevolking, met inbegrip van Chinezen, Indo-Europeanen en blanken. Ook op dit punt rees dus behoefte aan een ander woord. Onder Nederlanders die de woorden Nederlands-Indië en Inlanders wilden vermijden bestond nog steeds de gewoonte om van Java en Javanen te spreken, ook als zij de hele archipel en alle inheemsen bedoelden. Voor niet van Java afkomstige inheemsen was dit geen aantrekkelijk woordgebruik. Daarom ging de voorkeur nu uit naar de 
termen Indonesië en Indonesiërs, die in de taalwetenschap en de volkenkunde al jarenlang in zwang waren.

De eerste organisatie die deze nieuwe terminologie in haar naam gebruikte, droeg overigens in overwegende mate een Nederlands stempel. Dit was het Indonesisch Verbond van Studeerenden (IVS), een eind 1917 gevormd samenwerkingsverband van verenigingen van personen die zich voorbereidden op een werkkring in Indonesië. Het initiatief was uitgegaan van de Leidse Indologen Vereeniging onder leiding van H.J. van Mook. Nederlandse verenigingen van onder meer toekomstige bestuursambtenaren, legerofficieren, planters en zendelingen sloten zich bij dit verbond aan, tezamen met de Indische Vereeniging en Chung Hwa Hui. De eerste voorzitter van het IVS werd J.A. Jonkman, een jurist die zelf nog niet in Indonesië geweest was maar zich voorbereidde op een loopbaan bij de rechterlijke macht aldaar. Hij meende in die tijd, dat de Nederlandse 'voogdij' over de kolonie ten einde liep en dat de ethische politiek plaats zou moeten maken voor een 'Indonesischnationale' politiek. Van Mook, die wel in Indonesië geboren en opgegroeid was, werd secretaris-penningmeester. Ook hij stelde zich in op de komst van een zelfstandig Indonesië, dat op voet van gelijkheid plaats zou bieden aan inheemsen, Chinezen en Nederlanders. Hij vond het echter nog te vroeg voor een Indisch parlement. In plaats daarvan pleitte hij voor een geleidelijke ontwikkeling door de instelling van democratische organen op plaatselijk en vervolgens regionaal niveau.

Het IVS organiseerde in de jaren 1918-1922 een zestal congressen en verschillende andere bijeenkomsten. Hindia Poetra verscheen in deze periode als orgaan van het Verbond. Het oogmerk van de oprichters om de verschillende groepen nader tot elkaar te brengen werd onvoldoende bereikt. De politieke opvattingen van de Nederlandse en de Indonesische studenten liepen steeds verder uiteen en de congressen leidden dan ook herhaaldelijk tot verbale botsingen.

Intussen vertrok een deel van hen die in de IV en het IVS een rol gespeeld hadden, onder wie Soewardi, Ratoelangie, Van Mook en Jonkman, in 19181919 naar Indonesië. Omgekeerd kwamen in Nederland nu Indonesiërs studeren die al jaren van politieke beroering hadden meegemaakt. Onder hen was ook de arts Soetomo, eens de initiatiefnemer van Boedi Oetomo, die nu naar Nederland kwam voor een vervolgopleiding. In 1921 was hij voorzitter van de IV. Het jaar daarop veranderde de vereniging haar naam in Indonesische Vereeniging. In 1923 trok zij zich terug uit het IVS; kort daarna hield het Verbond op te bestaan. 


\section{Verharding van het Nederlands koloniaal beleid}

De in 1918 door Van Limburg Stirum afgelegde 'november-beloften' wekten een storm van verontwaardiging, zowel in Nederland als onder de Nederlanders in Indonesië. De voorzitter van de Tweede Kamer, D. Fock, die van 1905 tot 1908 minister van koloniën geweest was, bestempelde ze als 'onbegrijpelijke uitlatingen' en 'verwarring stichtende fantasieën'. Toch lagen die verklaringen in het verlengde van de lijn die de regering enige jaren eerder had uitgezet. De nu gerezen verontwaardiging getuigde er dan ook van, dat de Nederlandse houding tegenover de ontvoogding van Indonesië aan het veranderen was.

In 1908, toen Boedi Oetomo werd opgericht, stonden veel vooraanstaande Nederlanders welwillend tegenover het Indonesische emancipatiestreven. Zij dachten dat die emancipatie generaties zou vergen en dat de geëmancipeerde Indonesiërs de Nederlandse leiding nog lange tijd zouden aanvaarden. Maar in de sindsdien verstreken tien jaar was veel gebeurd dat vrijwel geen Nederlander verwacht had. Uit het emancipatiestreven was een nationale politieke beweging voortgekomen, die volgens haar eigen innerlijke logica op nationale onafhankelijkheid afkoerste.

Dit laatste ging de meeste Nederlanders (ook Van Limburg Stirum zelf) veel te ver. Velen vonden het daarom hoognodig deze gevaarlijke trend af te remmen. Zij verweten het gouvernement onder Van Limburg Stirum dat het de trend niet afremde maar juist aanmoedigde, niet alleen door de 'novemberbeloften' maar ook meer algemeen door een te meegaande houding tegenover organisaties als de Sarekat Islam. Een groot deel van de Nederlandse pers in Indonesië trok fel van leer tegen de ethische koers, die men graag als 'huilerig' of 'ziekelijk' betitelde. De aanvallen richtten zich ook op de gouverneurgeneraal persoonlijk en nog meer op diens adviseur Hazeu, die bij uitstek als representant van die koers beschouwd werd. Onder druk van deze campagne nam Hazeu eind 1919 ontslag; met hem vertrok de laatste hoge gouvernementsambtenaar die goede persoonlijke betrekkingen met leiders van de Indonesische beweging onderhield.

De overgrote meerderheid van het Nederlandse volk kon zich een door Indonesiërs bestuurd onafhankelijk Indonesië eenvoudig niet voorstellen. Men aanvaardde in Nederland het kolonialisme als een historisch gegeven en was er trots op dat men zelf tot de koloniale overheersers behoorde. Die overheerserspositie gaf de meeste Nederlanders ook geen gewetensproblemen. Het een halve eeuw eerder nog levendige besef, dat men Indonesië ten eigen bate exploiteerde, was naar de achtergrond gedrongen door het omstreeks de eeuwwisseling in zwang gekomen ethische woordgebruik. De meeste Nederlanders waren er inmiddels van overtuigd, dat het Nederlandse bewind de Indonesische bevolking tot zegen strekte en dat verbreking van de band tussen Nederland en Indië zowel de Nederlanders als de Indonesiërs zou schaden. 
De houding van de blanke Nederlanders in Indonesië zelf werd bovendien beïnvloed door enige aspecten die in Nederland geen rol speelden. Ten eerste was hun eigen maatschappelijke positie in het geding, omdat zij het aan de koloniale verhouding te danken hadden dat ze tot de bevoorrechte bovenlaag behoorden. Ten tweede was hun veiligheid in het geding, omdat zij in de kolonie weinig meer dan een duizendste van de bevolking vormden (en samen met de Indische Nederlanders nog geen half percent). Leger en politie waren voldoende in staat om plaatselijke relletjes en opstanden te onderdrukken, maar de opkomst van een Indonesische massabeweging riep het schrikbeeld op van grootschalig anti-Nederlands verzet.

Tegen deze achtergrond rees in 1918 en daarna de roep om een krachtiger beleid tegenover de Indonesische nationale beweging. Als richtsnoeren voor zo'n beleid werden vooral de volgende punten naar voren gebracht.

Strikte gezagshandhaving was van essentieel belang. Het gouvernement zou geen enkele toegeeflijkheid of wankelmoedigheid aan de dag mogen leggen tegenover hen die zich tegen het Nederlandse gezag keerden, maar zou de beschikbare machtsmiddelen zonder aarzeling moeten gebruiken om duidelijk te maken dat het geen aantasting van dat gezag zou dulden.

Tegelijk was het van belang de banden aan te halen met de inheemse aristocratie en de feodale vorsten, waar het Nederlandse gezag van oudsher op gesteund had. Zij waren de natuurlijke bondgenoten van Nederland, omdat ook hun positie bedreigd werd door de opkomst van de nieuwe elite die de motor van de nationale beweging vormde.

Verder diende men ervan uit te gaan dat er geen Indonesische natie bestond. Drie eeuwen geleden hadden de Nederlanders in de archipel allerlei volkeren aangetroffen, die niet alleen van taal en cultuur verschilden maar ook voortdurend in onderlinge conflicten gewikkeld waren. De sindsdien binnen de kolonie tot stand gekomen eenheid was uitsluitend een product van het Nederlandse bestuur. In de huidige fase moest men juist nadruk leggen op de onderlinge verscheidenheid van de bevolking.

De invloedrijkste pleitbezorger van zulk een beleid was $\mathrm{H}$. Colijn, een man die Abraham Kuyper na 1920 zou opvolgen als leider van de AntiRevolutionaire Partij (ARP). Colijn had als officier van het koloniale leger aan de strijd op Lombok en in Atjeh deelgenomen en was daarna zowel in Atjeh als in Batavia één van de naaste medewerkers van Van Heutsz geweest. Na terugkeer in Nederland werd hij afwisselend lid van het parlement en van de regering, onder meer als minister van oorlog en minister van financiën en in de jaren 1925-1926 en 1933-1939 als minister-president. Bovendien was hij van 1913 tot 1922 directeur van de Bataafsche Petroleum Maatschappij (BPM). Colijn betoogde al in 1918, dat de staatkundige ontwikkeling van NederlandsIndië niet in de richting van een eenheidsstaat moest worden geleid maar in die van een federalistische staat. Die staat zou een aantal eilanden en eilan- 
dengroepen met een aanzienlijke mate van zelfbestuur moeten omvatten, terwijl het centrale federale gezag nog lange tijd in Nederlandse handen zou blijven. In dat verband vond hij de instelling van de Volksraad een ernstige misgreep; hij zou die in de toekomst vervangen willen zien door een federale raad, bestaande uit vertegenwoordigers van de deelstaten. Colijn ontleende zijn denkbeelden gedeeltelijk aan de Britse regering, die begin 1918 plannen ontvouwd had voor een federalisering van India.

Een andere gezaghebbende criticus van de ethische koers was de liberaal M.W.F. Treub, die in de Wereldoorlog minister van financiën geweest was en in 1921 voorzitter werd van de Ondernemersraad voor Nederlandsch-Indië (zie p. 192). Ook hij propageerde een federalistische staatsinrichting. Hetzelfde gold voor F.C. Gerretson, een uitgesproken voorstander van de harde lijn in Nederlands-Indië. Gerretson had onder Colijn als staffunctionaris bij de BPM gewerkt, maar behoorde tot een andere protestants-christelijke partij, de Christelijk-Historische Unie.

Colijn, Treub en Gerretson publiceerden hun denkbeelden in verschillende brochures en artikelen en hadden aanzienlijke invloed binnen de regeringspartijen. In 1920 werd Colijn gepolst voor de post van gouverneur-generaal. Hij weigerde, onder meer omdat de regering niet wilde toezeggen de Volksraad tot een bescheidener positie terug te zullen brengen. Tot opvolger van Van Limburg Stirum benoemde de regering daarop oud-minister Fock, de man die hem in het parlement wegens de 'november-beloften' scherp bekritiseerd had.

De nieuwe gouverneur-generaal trad in 1921 aan en werd door de meeste Nederlanders in Indonesië met vreugde verwelkomd. Hij probeerde geen vertrouwen te winnen onder de leiders van de Indonesische beweging. De regering had hem in het bijzonder belast met het saneren van een toen bestaand tekort op de gouvernementsbegroting. Daartoe voerde hij een rigoureus bezuinigingsbeleid, onder meer door inkrimping van onderwijs en gezondheidszorg, terwijl tegelijkertijd de belastingdruk op de inheemse bevolking sterk werd opgevoerd. Van de kant van Nederland viel geen financiële hulp te verwachten, want ook daar was men bezig met een bezuinigingsoperatie.

Onder het bewind van Fock legde het gouvernement de politieke activiteiten van Indonesiërs steeds verder aan banden. Het verscherpte de voorschriften voor vergaderingen en verenigingen en breidde het politietoezicht uit. Tenslotte werden in 1926 zware strafbepalingen ingevoerd onder meer tegen uitingen waarin 'stemming wordt gemaakt' (ook zijdelings, voorwaardelijk of in bedekte termen) voor verstoring van de openbare orde of aanranding van het gezag (zie p. 137).

Er braken in deze jaren verscheidene stakingen uit. Wanneer dit overheidspersoneel betrof, wist het gouvernement er meestal snel een eind aan te maken, onder meer door de stakers terstond te ontslaan en, wanneer ze in dienstwoningen woonden, uit hun huis te zetten. Maar ook tegen stakingen bij 
particuliere ondernemingen trad het gouvernement soms hard op, vooral na de invoering in 1923 van een strafbepaling tegen het teweegbrengen van stakingen die konden leiden tot verstoring van de openbare orde of ontwrichting van het economisch leven.

De verandering van het politieke klimaat betrof niet alleen het optreden van de overheid. Terwijl in de Volksraad van 1918 de conservatieve leden een minderheid vormden, kregen ze bij de verkiezingen van 1921 een ruime meerderheid. De achtergrond hiervan was dat de conservatief gezinde Nederlanders in Indonesië in de jaren 1908-1918 nauwelijks hadden deelgenomen aan de verkiezingen voor plaatselijke en regionale raden, waardoor de hervormingsgezinde Nederlanders toen niet alleen onder de leden van die lichamen sterk vertegenwoordigd waren geraakt, maar ook in de door deze raadsleden in 1918 gekozen Volksraad. De sindsdien opgekomen agitatie tegen de ethische koers had de politieke belangstelling van de conservatieve Nederlanders aanzienlijk vergroot.

Wat de leiders van de Indonesische beweging betreft, keerden Abdoel Moeis, Tjipto Mangoenkoesoemo en Tjokroaminoto in 1921 niet in de Volksraad terug. Wel werd een andere voorman van de Sarekat Islam, Agoes Salim, nu tot lid benoemd.

\section{Het Indo-Europeesch Verbond}

In de jaren 1912 en 1913 dachten sommige Indo-Europeanen, dat hun bevolkingsgroep een leidende rol zou kunnen spelen wanneer Indonesië onafhankelijk zou worden en de blanke Europeanen het land zouden verlaten. Tot degenen die zo dachten behoorden E.F.E. Douwes Dekker en een deel van zijn aanhang in de Indische Partij. De stormachtige ontwikkeling van de Indonesische emancipatiebeweging in de daarop volgende jaren maakte niet alleen een eind aan deze gedachte, maar gaf ook voedsel aan een omgekeerde verwachting. Velen vreesden dat de Indo-Europese bevolkingsgroep in een door de Indonesiërs zelf geleide onafhankelijke staat een onderdrukte minderheid zou worden. Zo gezien hadden de Indo-Europeanen belang bij handhaving van het koloniale bestel. Intussen ondervonden zij ook in dit bestel al achterstelling op velerlei gebied, terwijl hun positie verder onder druk kwam te staan door de snelle toename van westers opgeleide Indonesiërs, die onder meer met hen concurreerden op de arbeidsmarkt voor administratief werk. Een en ander wekte onder de Indo-Europeanen de wens, hun krachten te bundelen om hun positie te verbeteren en zich tegen de Indonesische emancipatiebeweging af te zetten.

Tegen deze achtergrond kwam in 1919 een nieuwe organisatie tot stand, het Indo-Europeesch Verbond (IEV). Het verbond wilde de intellectuele en 
economische ontwikkeling van de Indo-Europeanen bevorderen, stelling nemen tegen iedere bedreiging van hun belangen en zich verzetten tegen aantasting van het Nederlandse gezag in Nederlands-Indië. Het hield zich onder meer bezig met het oprichten van scholen en met pogingen tot het vormen van een Indo-Europese boerenstand. Ten behoeve van dit laatste stichtte het enige landbouwkolonies op Java en Sumatra.

Hoewel het IEV zich als een niet-politieke belangenorganisatie had aangediend, ging het toch een politieke rol spelen. Met ingang van 1924 stelde het eigen kandidaten voor de plaatselijke raden en de Volksraad. In de Volksraad kreeg het eerst vier, later zes en uiteindelijk acht vertegenwoordigers; dezen steunden waar mogelijk het gouvernement tegen de oppositie. Het IEV telde in de jaren dertig ongeveer twaalfduizend leden en was daarmee de grootste partijgroepering onder de Europese bevolking van de kolonie.

\section{De Nationaal-Indische Partij}

Zoals op p. 163 vermeld hadden de drie leiders van de voormalige Indische Partij in 1913 Nederlands-Indië moeten verlaten en waren de activiteiten van de partij voortgezet onder de vlag van de vereniging Insulinde, die van oorsprong een organisatie van Indo-Europeanen was. Tjipto Mangoenkoesoemo mocht in 1914 terugkeren en woonde daarna enige tijd in Semarang, waar Insulinde haar hoofdzetel had. Hij was ook lid van de ISDV en ontwikkelde zich daarin tot een tegenstander van Sneevliet. In 1918 werd hij tot lid van de Volksraad benoemd. In datzelfde jaar kreeg Douwes Dekker toestemming tot terugkeer, maar een groot deel van zijn vroegere aanhang had zich intussen van Insulinde afgekeerd. De meeste Indo-Europeanen wilden nu de band met Nederland niet losser maken maar juist versterken; enige tijd later leidde dit tot de oprichting van het in de vorige paragraaf besproken Indo-Europeesch Verbond.

In 1919 zette Douwes Dekker met een kleine groep volgelingen Insulinde om in een nieuwe partij, waarvan de statuten in aangescherpte vorm aan de vroegere Indische Partij ontleend waren en het einddoel omschreven als 'volkomen onafhankelijkheid van Indië'. De partij kreeg als Nederlandse naam Nationaal-Indische Partij (NIP) en als Maleise naam Sarekat Hindia (SH). Voorzitter werd eerst Soewardi Soerjaningrat, die nu eveneens was teruggekeerd, en later Tjipto Mangoenkoesoemo. Deze nieuwe partij bleek echter ook onder Indonesiërs niet populair te worden. De verhoudingen tussen de bevolkingsgroepen waren al zo gepolariseerd dat de multiraciale grondslag van de partij velen afstootte. Bovendien voelden veel revolutionair gezinden zich meer aangetrokken tot de PKI. Het gouvernement gaf de partij weinig gelegenheid zich te ontplooien en hield haar aanvraag om erkenning jarenlang aan. Soewardi werd al in 1919 enige tijd vastgehouden. Douwes Dekker zat 
van januari 1920 af ruim een jaar in voorlopige hechtenis. Aan Tjipto werd het verblijf in Semarang en een groot deel van de rest van Java verboden. Soewardi en Douwes Dekker trokken zich geleidelijk uit hun partijpolitieke activiteiten terug en gingen zich bezighouden met onderwijshervorming (zie p. 185). De NIP/SH viel ten prooi aan interne conflicten en hief zichzelf begin 1923 op. Omstreeks dezelfde tijd wees het gouvernement de aanvraag om erkenning af.

\section{De non-coöperatiepolitiek}

Hoewel de vroegere leiders van de Indische Partij geen succes hadden met hun nieuwe partij, de NIP/SH, oefenden zij een blijvende invloed op de Indonesische nationale beweging uit door hun pleidooien voor een nieuwe strategie, de 'non-coöperatie'. Zij ontleenden deze strategie aan de nationale beweging van India.

De in 1917 door de Britse regering gedane toezeggingen over stappen in de richting van autonomie konden niet verhinderen, dat de spanningen tussen de bevolking van India en het koloniale bestuur in de volgende jaren sterk toenamen. Het bestuur voerde nieuwe repressieve wetten in. Een protestbeweging daartegen werd georganiseerd door Mohandas K. Gandhi, die al een reputatie had als ontwerper en toepasser van methodes van geweldloos verzet. Tijdens een langdurig verblijf in Zuid-Afrika had hij geslaagde campagnes gevoerd tegen de achterstelling van de daar wonende Indiërs. Na zijn terugkeer in 1915 had Tagore hem de eretitel Mahatma (Grote Ziel) gegeven.

In april 1919 vond een rampzalig incident plaats in de Indiase stad Amritsar. Enige dagen nadat daar drie Britse burgers in een volksoproer gedood waren, liet een Britse generaal zonder waarschuwing op een ongewapende menigte schieten, met als gevolg honderden doden en ruim duizend gewonden. Het bloedbad van Amritsar verbitterde veel nationalisten zozeer, dat zij geen waardering konden opbrengen voor de hervormingen die het Britse parlement in datzelfde jaar neerlegde in de Government of India Act. Ook bracht het Gandhi ertoe, de leiding van de Indiase nationale beweging op zich te nemen en een nieuwe strategie te lanceren voor de verovering van Indiaas zelfbestuur. Hij betoogde dat men niet tegelijkertijd met het koloniale bestuur kon samenwerken en zich ertegen verzetten. Daarom moesten de Indiërs die samenwerking op allerlei terreinen verbreken, zich terugtrekken uit vertegenwoordigende en rechterlijke organen, niet deelnemen aan verkiezingen, geen onderwijs op gouvernementsscholen volgen en geen uit Groot-Brittannië ingevoerde waren kopen. In 1920 schaarde zowel een grote moslimbeweging als het Indian Congress zich achter de non-co-operation strategie.

In de loop van 1921 werden de tegenstellingen tussen de Indiase nationa- 
listen en het koloniale bestuur steeds scherper. Het Congress riep de Indiase militairen op tot desertie en de Indiase ambtenaren tot het verlaten van de overheidsdienst. Tienduizenden Indiërs werden opgepakt wegens passief of actief verzet. Gandhi had voorspeld dat de non-coöperatiecampagne in één jaar tot zelfbestuur voor India zou leiden, maar toen deze voorspelling niet uitkwam begon de campagne te verlopen. Gandhi tartte het koloniale bestuur door te verkondigen, dat de campagne een opstandige beweging was die ten doel had dit bestuur ten val te brengen. Tenslotte werd hij in maart 1922 gearresteerd en tot zes jaar gevangenisstraf veroordeeld. De non-coöperatiebeweging hield geen stand. In 1923 besloot het Congress alsnog in te stemmen met deelname aan de nieuwe verkiezingen. In 1924 werd Gandhi vervroegd vrijgelaten; hij trok zich daarna enige jaren uit de politiek terug.

Vooral dank zij Soewardi en Tjipto maakte de non-coöperatiegedachte van 1921 af school in Indonesië, waar het verzet tegen de Indië Weerbaarcampagne al velen hiervoor ontvankelijk had gemaakt. De keuze tussen coöperatie en non-coöperatie is de Indonesische nationale beweging sindsdien tot aan de onafhankelijkheid blijven bezighouden. Politici presenteerden zich als coöperatoren of non-coöperatoren en er kwamen coöperatieve partijen naast non-coöperatieve partijen. Zelfs het meestal zo gezagsgetrouwe Boedi Oetomo onderschreef korte tijd de non-coöperatiegedachte. Overigens was de Indonesische non-coöperatiebeweging geen slaafse navolging van de Indiase en hadden Indonesische nationalisten soms kritiek op de uitwerking die men in India aan de non-coöperatiegedachte gegeven had. Ook onderling verschilden deze nationalisten herhaaldelijk van mening over de consequenties van die gedachte. Volgens de meesten bracht non-coöperatie in ieder geval mee dat men geen dienst nam bij de koloniale overheid, maar anderen vonden het al voldoende dat men niet meedeed aan de Volksraad. De door Gandhi voorgestane boycot van gouvernementele onderwijsinstellingen vond in Indonesië geen enkele steun.

In het begin werd non-coöperatie in Indonesië vooral bepleit als een uiting van protest tegen het asociale beleid van het bewind-Fock en de schending van de november-beloften. Al spoedig ging men non-coöperatie als een moreel beginsel zien ('geen samenwerking met de overheersers!'). Later kreeg de zienswijze de overhand, dat het niet om een beginsel maar om een strijdmethode ging. In die zienswijze was het telkens een tactische en niet een morele kwestie, of men onder de gegeven omstandigheden langs de weg van coöperatie dan wel van non-coöperatie de beste kansen had om het einde van de koloniale overheersing naderbij te brengen. Hieruit volgde dat ook de keus voor coöperatie een tactische keus was en niet betekende dat men partij koos voor de overheersers. Na 1930 versmalde het onderscheid tussen coöperatie en non-coöperatie zich tot de vraag, of men wel of niet bereid was zitting te nemen in de Volksraad en andere vertegenwoordigende lichamen. 
De wilde scholen

Niet alleen het gouvernementele maar ook het niet-gouvernementele onderwijs onderging in de twintigste eeuw een grote uitbreiding. Bevordering van onderwijs was een belangrijke doelstelling van vrijwel iedere emancipatiebeweging in Indonesië. Dit gold ook voor andere bevolkingsgroepen dan de Indonesiërs zelf: in het begin van de eeuw waren het de Chinezen die de eerste moderne niet-gouvernementele scholen oprichtten en twee decennia later hield ook het Indo-Europeesch Verbond zich met het stichten van scholen bezig. De belangrijkste uitbreidingen van het niet-gouvernementele onderwijs werden echter door en voor de Indonesische bevolkingsgroep tot stand gebracht.

Bij Boedi Oetomo en de Sarekat Islam was de oprichting van scholen een nevenactiviteit. De eerste organisatie die er een hoofdactiviteit van maakte was de Moehammadiah, een beweging die zich inzette voor hervorming van de islam in moderne zin. Evenals de Sarekat Islam was deze vereniging in 1912 opgericht, maar zij bewoog zich buiten de politiek. Tot 1921 werkte zij alleen in het sultanaat Jogjakarta; daarna breidde ze zich uit over de hele archipel. Naar het voorbeeld van de christelijke zending en missie combineerde de Moehammadiah de verbreiding van haar religieuze boodschap met de oprichting van ziekenhuizen en weeshuizen en vooral van scholen. Behalve godsdienstscholen richtte zij ook gewone scholen op. In 1940 waren dit er zevenhonderd, deels met onderwijs op inheemse grondslag en deels met onderwijs op westerse grondslag; voor een aantal van de laatste scholen kreeg zij subsidie van het gouvernement.

Naast de Moehammadiah-scholen, die geen politieke inslag hadden, kwamen er in de jaren twintig en dertig talloze niet-gouvernementele scholen die onderricht gaven in een meer of minder uitgesproken antikoloniale geest. Zulke scholen noemde men 'wilde scholen'.

De pionier op dit gebied was de Minangkabauer Ibrahim Tan Malaka. Hij was in zijn jeugd door een Nederlandse docent naar Nederland meegenomen, waar hij een onderwijzersopleiding gevolgd had en met het communisme kennis gemaakt had. Eind 1919 keerde hij naar Indonesië terug. Medio 1921 opende hij een eigen school in Semarang onder auspiciën van de daar door marxisten geleide afdeling van de Sarekat Islam. Tan Malaka gaf er onderricht op westerse grondslag volgens een door hemzelf bedacht systeem en leerde zijn scholieren ook het socialistische strijdlied 'De Internationale'. De toeloop tot deze school was aanzienlijk; binnen een jaar kwamen nog meer van zulke rode scholen tot stand en in 1925 waren er enige tientallen. Door het optreden van het gouvernement konden deze scholen zich echter niet handhaven. Een duurzamer bestaan viel ten deel aan nieuwe scholen die gesticht werden door twee leiders van de voormalige Indische Partij, Douwes Dekker en Soewardi Soerjaningrat. 
In 1921 besloot Soewardi, die evenals Tan Malaka een Nederlandse onderwijzersopleiding gevolgd had, zich verder te wijden aan de opbouw van een nationaal onderwijsstelsel. Geïnspireerd door de ideeën van Rabindranath Tagore wilde hij het zuiver intellectuele en materialistische westerse onderricht niet nabootsen, maar westerse kennis op een harmonische wijze combineren met de Javaanse cultuur en andere Aziatische cultuurelementen. Om duidelijk te maken dat hij een nieuw leven begon, nam Soewardi een nieuwe naam aan: Ki Hadjar Dewantoro (Leraar-Boodschapper van de Goden). Zijn scholen noemde hij Taman Siswa (Leerlingentuin). In 1922 werd in Jogja de eerste Taman Siswa-school geopend; in 1940 waren het er tweehonderdvijftig. De voertaal van dit onderwijs was de streektaal, de ideologische grondslag was nationalistisch maar niet islamitisch. Het gouvernement zag de Taman Siswa-scholen eerst vooral als kweekbedden van antikoloniaal sentiment; later kreeg het meer waardering voor hun kwaliteit. Dewantoro stond oorspronkelijk op een strikt non-coöperatiestandpunt, maar toonde zich in de jaren dertig alsnog bereid om subsidie van het gouvernement te aanvaarden.

Douwes Dekker begaf zich in 1922 eveneens in het onderwijs. Hij stichtte in Bandoeng een eigen onderwijsorganisatie, met uiteindelijk vijf lagere scholen en vier beroepsopleidingen. Hij noemde zijn organisatie het Ksatrian Instituut, naar een benaming van edele ridders in de Javaanse mythologie. Hoewel er in het begin klachten kwamen over het anti-Nederlandse karakter van zijn lessen geschiedenis en aardrijkskunde, gaf het gouvernement later toch gedurende een aantal jaren subsidie aan zijn instituut. Ook hij nam een nieuwe naam aan, Setiaboedi (Trouw van Inborst).

De toeloop tot deze en allerlei andere wilde scholen was groot, omdat de gouvernementsscholen nooit konden voldoen aan de stijgende vraag naar westers onderwijs. Niet alleen hield de uitbreiding van het gouvernementsonderwijs geen gelijke tred met de toename van de Indonesische bevolking, maar de bezuinigingen onder het bewind van gouverneur-generaal Fock leidden zelfs tot sluiting van scholen en ontslag van docenten. Kinderen die geen plaats hadden kunnen krijgen op de HIS stroomden in grote getale naar de wilde scholen. Het gouvernement subsidieerde deze scholen gewoonlijk niet. De docenten in dit particuliere onderwijs waren voor een deel geschoolde leerkrachten die geen plaats op een gouvernementsschool gekregen hadden of daar waren ontslagen, dan wel daar niet wilden werken omdat ze zich op noncoöperatief standpunt stelden. Een ander deel van die docenten bezat geen onderwijsopleiding. Dit waren vaak jonge Indonesiërs die wel westers onderwijs gevolgd hadden, maar vervolgens geen daaraan beantwoordende betrekking hadden kunnen krijgen en nu zelf onderwijs gingen geven om in hun onderhoud te voorzien. In het bijzonder bestond er onder de bevolking een bijna onuitputtelijke behoefte aan onderricht in het lezen en schrijven van de Nederlandse taal. Tegen het eind van de jaren dertig telde het wilde onderwijs 
meer dan tweemaal zoveel leerlingen als het gouvernementele onderwijs.

De antikoloniale inslag van de meeste wilde scholen was een bron van zorg voor het gouvernement. In 1923 vaardigde het een ordonnantie uit die ieder die particulier onderwijs wilde geven verplichtte om het bestuur daar van te voren over in te lichten en om controlerende ambtenaren bij de lessen toe te laten. Het gewestelijk bestuur kreeg de bevoegdheid om in het belang van de openbare orde aan een docent het geven van zulk onderwijs te verbieden.

Het koloniale bestuur had overigens ook zorgen over de docenten aan de gouvernementsscholen, zowel de Europese als de Inlandse. In een circulaire van 1924 bedreigde het hen met ontslag als zij geen matiging in acht zouden nemen in hun optreden, niet alleen binnen de school maar ook daarbuiten bij politieke propaganda, vakbondsacties en soortgelijke activiteiten.

\section{Machtsstrijd tussen de Sarekat Islam en de marxisten}

De marxist Sneevliet en zijn volgelingen wilden het Nederlandse kolonialisme bestrijden in het kader van de internationale klassenstrijd tegen alle vormen van kapitalisme. Massa-actie zou daarbij het belangrijkste strijdmiddel moeten vormen. Omdat hun eigen organisatie, de Indische Sociaal-Democratische Vereeniging (ISDV), maar een paar honderd leden telde, probeerden zij greep te krijgen op de enige toen bestaande Indonesische massa-organisatie, de Sarekat Islam.

Sneevliet's discipel Semaoen werd in 1917 voorzitter van de twintigduizend leden tellende afdeling Semarang van de SI en kon daardoor gaan optreden als leider van een linkse oppositie binnen de nationale SI. Onder meer viel hij Abdoel Moeis scherp aan wegens diens steun aan de Indië Weerbaar-campagne. Een jaar later werd de door Moeis aangevoerde rechtervleugel van de SI versterkt, toen Agoes Salim in de leiding van de SI kwam. De Minangkabauer Salim was een Staatsblad-Europeaan (zie p. 133), die vijf jaar op het Nederlands consultaat in Djeddah had gewerkt, lid was geweest van de commissie-Carpentier Alting en vertrouwen genoot bij het gouvernement. Binnen de SI beklemtoonde hij vooral de islamitische grondslag van de organisatie. Tjokroaminoto zelf hechtte aan ideologische kwesties minder belang dan aan het bijeenhouden van zijn organisatie. Met zijn steun kregen Semaoen en Darsono belangrijke functies in de nationale SI. Ook maakte de SI een gebaar in socialistische richting door het 'zondige kapitalisme' te veroordelen, maar Tjokroaminoto legde uit dat men hiermee alleen uitheems kapitalisme bedoelde.

De politieke opstelling van de Sarekat Islam werd geleidelijk radicaler. Op het congres van 1917 overheerste nog de hoop dat aan de koloniale verhouding langs evolutionaire weg een eind zou kunnen komen; de partij stemde 
dan ook in met de aanwijzing van SI-kandidaten voor de Volksraad. In 1918 was die hoop aanzienlijk verminderd. Het SI-congres eiste nu op korte termijn stappen in de richting van volledig zelfbestuur. Het volgend jaar kwam de SI in ernstige moeilijkheden omdat SI-leden verdacht werden van betrokkenheid bij enige gewapende incidenten op Celebes en Java. Er bleek bovendien in West-Java naast de officiële SI-organisatie een geheime revolutionair gezinde 'Afdeling B' te bestaan. Een deel van de gematigde leden keerde zich van de SI af. De aanhang van de organisatie liep trouwens al sinds 1916 terug, vooral in de dorpen, waar veel traditionele hoofden zich inspanden om de SI-invloed terug te dringen. De radicalisering van de SI leidde verder tot het verlies van de financiële steun van een aantal Arabische handelaren.

$\mathrm{Nu}$ de positie van de SI onder de boeren zwak geworden was, probeerde zij haar positie onder de arbeiders te versterken. Prominente SI-leden namen leidende functies in de vakbeweging op zich en de SI bevorderde de oprichting van een overkoepelende vakcentrale. Eind 1919 kwam deze centrale tot stand, met Semaoen als voorzitter. Tientallen vakbonden sloten zich erbij aan, maar de centrale viel al spoedig ten prooi aan interne conflicten, onder meer over de vraag of men staking ook als middel voor politieke doeleinden moest gebruiken. Na anderhalf jaar liep dit uit op een scheuring, waarbij Semaoen zich afscheidde en een eigen vakcentrale stichtte.

Intussen waren de in de ISDV verenigde marxisten zich communisten gaan noemen, hadden zij hun vereniging omgedoopt tot Perserikatan Kommunist di India (PKI) en hadden zij Semaoen tot voorzitter gekozen. Ook had de PKI zich aangesloten bij de in Moskou gevestigde internationale organisatie van communistische partijen, de Komintern. Om greep te krijgen op de massaaanhang van de SI richtte de PKI zich niet alleen op het verwerven van invloed aan de top, maar ook aan de basis. Dit werd vergemakkelijkt doordat de SI geen strak geleide organisatie was maar een soort federatie van plaatselijke bonden. In een aantal van die bonden kregen de communisten de leiding in handen; dit werden 'rode' SI-bonden.

Binnen de centrale leiding van de SI verzetten vooral Abdoel Moeis en Agoes Salim zich tegen de communistische pogingen om de organisatie over te nemen. Als bewijs dat de communisten tegen de islam waren, konden zij wijzen op een uitdrukkelijke veroordeling van het pan-islamisme door de Komintern. Tjokroaminoto probeerde nog een tijd lang met de communisten samen te werken, maar werd niettemin fel door hen aangevallen. Tenslotte kwam aan deze samenwerking een eind op het nationale SI-congres van oktober 1921, enige maanden na de scheuring in de vakcentrale. Tjokroaminoto ontbrak op dit congres, omdat hij in de zomer gearresteerd was op verdenking van meineed in de Afdeling B-affaire. Salim voerde tegen de communistische propaganda aan, dat de profeet Mohammed de beginselen van het historisch materialisme al twaalf eeuwen vóór Marx verkondigd had. Met grote meer- 
derheid besloot het congres op voorstel van Moeis en Salim met de communisten te breken door SI-leden te verbieden ook lid van een andere partij te zijn. Naar aanleiding hiervan maakte een tiental rode SI-bonden zich los van de centrale SI-organisatie.

Kort na het congres vertrok Semaoen voor enige maanden naar Rusland. Omdat ook Darsono zich in die tijd in Europa bevond, werd Tan Malaka nu voorzitter van de PKI. Hij had zich ontwikkeld tot de belangrijkste ideoloog van de partij. Als PKI-voorzitter streefde Tan Malaka naar een verzoening met de SI, maar zijn voorzitterschap was van korte duur. Begin 1922 brak een staking uit onder het Indonesische personeel van de gouvernementspandhuisdienst. Het gouvernement toonde zich onverzoenlijk en ontsloeg alle stakers. Zowel de SI als de PKI en verscheidene vakbonden namen het voor de stakers op, waarbij Tan Malaka tenslotte tot een algemene solidariteitsstaking opriep. Niettemin verliep de staking binnen enkele weken. Op grond van de exorbitante rechten besloot het gouvernement nu Tan Malaka op Timor te interneren, maar op zijn verzoek stond het hem toe, in plaats daarvan Indonesië te verlaten. Tan Malaka ging naar Nederland, waar de communistische partij hem kandidaat stelde bij de parlementsverkiezingen, en verbleef vervolgens in Moskou, totdat de Komintern hem eind 1923 als agent voor Zuidoost-Azië naar China stuurde.

Tjokroaminoto kwam medio 1922 weer vrij. Ook hij zag nu in dat de PKI zich van zijn organisatie meester wilde maken. De intussen uit Rusland teruggekeerde Semaoen probeerde vergeefs de samenwerking met de SI te herstellen. Het SI-congres van februari 1923 bevestigde de uitsluiting van de communisten definitief. Hierop besloot de PKI de strijd met de SI hard tegen hard te voeren en overal waar SI-bonden waren eigen bonden op te richten met de naam Sarekat Rakjat (SR, Volksbond). Inderdaad kwamen zulke bonden van de grond, hoewel niet alle rode SI-bonden bereid waren zich tot SR-bonden om te vormen, omdat zij zich dan geheel aan de PKI-leiding moesten onderwerpen.

Semaoen kon overigens niet lang leiding geven aan de nieuwe PKIstrategie. In mei 1923 werd hij gearresteerd. De Vereeniging van Spoor- en Tramwegpersoneel (VSTP), waarvan hij voorzitter was, reageerde daarop met een algemene spoorwegstaking. Het gouvernement maakte met harde hand een eind aan deze staking en verbande Semaoen op basis van de exorbitante rechten uit Indonesië, waarna hij zich eerst in Nederland en later in de Sovjetunie vestigde. De leiding van de PKI ging nu over op Darsono, die begin 1923 was teruggekeerd na ruim anderhalf jaar in Moskou en Berlijn bij de Komintern te hebben gewerkt.

Dank zij de rode SI-bonden en de SR-bonden nam de communistische aanhang sterk toe. Een groot deel van die aanhang wist overigens weinig van de communistische leer en liet zich ook leiden door islamitische denkpatro- 
nen en Javaanse heilsverwachtingen. Wat deze bonden vooral kenmerkte, was hun revolutionaire gezindheid. Intussen riep hun optreden reacties op in de vorm van de oprichting van anti-communistische bonden. Deze noemden zich Sarekat Hidjau (Groene Bond), omdat groen als kleur van de islam geldt. Het kwam herhaaldelijk tot gewelddadigheden tussen rode en groene bonden. De PKI slaagde er niet in haar aanhang tot een gedisciplineerde organisatie om te smeden. Overigens veranderde zij in 1924 haar naam in Partai Komunis Indonesia.

Hoewel de communistische strategie niet op verovering van de Sarekat Islam uitliep, droeg ze er wel toe bij deze ernstig te verzwakken. Daarbij bleek uit de vorming van de rode SI-bonden, dat de SI-organisatie juist door haar losse structuur kwetsbaar was. Aan de andere kant had haar moslimgrondslag door het conflict met de PKI een veel sterkere nadruk gekregen. In de jaren 1923-1927 voerde de SI een algehele reorganisatie door, waarbij de federale structuur plaats maakte voor die van een strak geleide partij. De afgeslankte nieuwe organisatie ging Partai Sarekat Islam heten en richtte zich in hoofdzaak op religieuze en sociale activiteiten. Abdoel Moeis trok zich grotendeels uit de politiek terug.

\section{Hervorming van het Nederlands-Indische staatsbestel}

De Nederlandse regering hield zich in de jaren twintig herhaaldelijk bezig met hervormingen van het bestuursstelsel van Nederlands-Indië. Eén van die hervormingen betrof het overhevelen van taken van het Europese korps naar het Inlandse korps van het Binnenlands Bestuur. Al voor 1920 was het gouvernement in sommige gebieden op Java begonnen de adspirant-controleurs en controleurs uit het binnenland terug te trekken en het door hen uitgeoefende toezicht over te dragen aan de inheemse districtshoofden. De taakverdeling tussen de beide korpsen werd nu verder herzien, terwijl de omvang van het Europese korps werd verkleind. Het bestuur van alle regentschappen op Java kwam grotendeels te berusten bij de inheemse regenten en de door hen voorgezeten regentschapsraden, terwijl de Nederlandse assistent-residenten in hoofdzaak een adviserende rol kregen. Aldus verlichtte men niet alleen de taak van het Europees BB, maar versterkte men ook de positie van de inheemse ambtsaristocratie.

In de tweede plaats hervormde de regering het bestuursstelsel ten behoeve van een verdere decentralisatie. Ondanks de in de eerste decennia van de eeuw uitgevoerde decentralisatie werden nog steeds alle gewichtige beslissingen in Batavia of Buitenzorg genomen. Om hierin verlichting te brengen werd de mogelijkheid geschapen, tussen het gouvernement en de residenten een nieuwe bestuurslaag in te voegen. Zo kwamen er op Java drie provincies, 
onder gouverneurs die werden bijgestaan door provinciale raden. De nieuwe bestuurseenheden kregen echter geen belangrijke autonome bevoegdheden, zoals de Britse regering in deze tijd wél verleende aan de provincies van India.

Terwijl de regering weinig gehoor gaf aan de pleidooien van rechtse politici voor een federale staatsinrichting van Nederlands-Indië, hechtte zij evenmin veel betekenis aan het door linkse politici toegejuichte rapport van de commissie-Carpentier Alting (zie pp. 173). Wel had zij naar aanleiding van dat rapport enige voorstellen tot grondwetswijziging ingediend. De hierop in 1922 van kracht geworden nieuwe grondwetsbepalingen hadden onder meer voorgeschreven dat de staatsinrichting van Nederlands-Indië door de wet zou worden vastgesteld. Pas nu bleek echter dat de regering van plan was daarbij de voorstellen van de commissie grotendeels te negeren.

Deze houding van de regering wekte verontwaardigde reacties. In Indonesië leidde dit tot samenwerking van organisaties als Boedi Oetomo en Sarekat Islam met hervormingsgezinde Nederlanders in een gelijksoortig verband als al in 1918 in de Volksraad had bestaan. Dit samenwerkingsverband werd daarom wel 'de tweede Radicale Concentratie' genoemd. Daarbij richtte men een Comité voor de Autonomie van Indië op, dat ijverde voor invoering van de door de commissie-Carpentier Alting voorgestelde hervormingen. Het Comité wilde een delegatie naar Nederland sturen onder leiding van Achmad Djajadiningrat, regent van Serang (Bantam) en sinds 1918 lid van de Volksraad, maar dank zij de ambtenarenstatus van de regenten wist het gouvernement dit te verijdelen. In Nederland werd de regering fel aangevallen door de hoogleraren van de Leidse indologenopleiding. Naast beroemdheden als Van Vollenhoven en Snouck Hurgronje behoorden daartoe nu onder meer ook Carpentier Alting zelf en Hazeu.

Terwijl deze protesten uit Indonesië en Nederland zich richtten tegen de onwil van de regering om grote stappen in de richting van Indisch zelfbestuur te zetten, werd de regering ook aangevallen door rechtse politici die vonden dat zij in die richting al veel te ver ging. M.W.F. Treub schreef in een brochure dat Indië binnen een mensenleeftijd van Nederland zou worden losgescheurd als de regeringsvoorstellen wet zouden worden. Daar kwam nog bij, dat de standpunten over het koloniaal beleid zich verhardden door een controverse over versterking van de marine. De regering had een ontwerp-vlootwet ingediend, die voorzag in de bouw van nieuwe oorlogsschepen voor de externe verdediging van Nederlands-Indië. Dit wetsontwerp was zeer omstreden, omdat het grote uitgaven meebracht terwijl de regering tegelijkertijd ingrijpende bezuinigingsmaatregelen wilde nemen. Het partijblad van de ARP ondersteunde het vlootplan als volgt: 'We moeten Indië houden! Omdat we den band aan de historie voelen! Omdat we eerbied willen betonen aan het bloeitijdperk onzer volkshistorie! Omdat onze welvaart in zoo sterke mate 
van Indië afhankelijk is. [...] We moeten Indië houden!' Uiteindelijk werd het wetsontwerp met 49 tegen 50 stemmen verworpen. De verwerping van de vlootwet maakte partijen als de ARP nog minder bereid om op het punt van het Nederlands-Indische staatsbestel aan de oppositie tegemoet te komen.

In 1925 aanvaardde het parlement de vernieuwde wet op de staatsinrichting van Nederlands-Indië, met tegenstemmen van de vrijzinnig-democraten en de sociaal-democraten. In plaats van als Regeeringsreglement zou deze wet voortaan worden aangeduid als Indische Staatsregeling. Wat de inhoud betreft was een nieuwe naam overigens niet nodig geweest, omdat de oude wet al zo vaak was bijgesteld.

De voornaamste nieuwe elementen in de wet hadden betrekking op de Volksraad, die nu medewetgevende bevoegdheid kreeg. Voor alle ordonnanties (de Nederlands-Indische vorm van wetten) moest de gouverneur-generaal overeenstemming met de Raad zien te krijgen; de Raad mocht de ontwerpen wijzigen en mocht ook zelf ontwerp-ordonnanties voorstellen. Konden de gouverneur-generaal en de Raad het over een ontwerp-ordonnantie niet eens worden, dan besliste uiteindelijk de Nederlandse regering. De ontwerp-begroting moest eveneens in overeenstemming met de Volksraad worden opgesteld; de uiteindelijke vaststelling gebeurde dan bij Nederlandse wet. Verder moest de Nederlandse regering advies van de Volksraad vragen over alle ontwerpen van wetgeving die uitsluitend of in belangrijke mate op Nederlands-Indië betrekking hadden.

De nieuwe wet bracht de zittingsduur van de Volksraad op vier jaar en het ledental op 61, van wie 38 gekozen en 23 benoemd. Het kiesrecht voor de verkiesbare leden bleef berusten bij de leden van de plaatselijke en regionale raden, maar voortaan volgens een raciaal gesplitst systeem: Indonesiërs, Nederlanders en 'uitheemse onderdanen' (voornamelijk Chinezen en Arabieren) mochten alleen nog maar stemmen over kandidaten uit hun eigen categorie. Bovendien gold voor de verkiezing van de Indonesische leden een verdeling van de archipel in twaalf kieskringen, zodat bijvoorbeeld de kiezers op Celebes alleen kandidaten uit Celebes konden kiezen. Een en ander zou een verdere verschuiving in conservatieve richting meebrengen, omdat hervormingsgezinde Nederlanders geen zetel meer konden krijgen door Indonesische stemmen en omdat nationaal bekende Indonesische politici niet meer verkozen konden worden met stemmen buiten hun kieskring. Overigens bestonden de plaatselijke en regionale raden voor een groot deel uit leden die zelf niet gekozen maar benoemd waren, met als gevolg dat de gekozen leden van de Volksraad werden gekozen door kiezers van wie bijna de helft door het gouvernement benoemd was.

$\mathrm{Nu}$ de Volksraad medewetgevende bevoegdheid kreeg, voerde de wet een nieuwe werkwijze in omdat de Raad het grootste deel van het jaar niet in zitting bijeen was. In de toekomst zouden de meeste bevoegheden van de 
Raad tussen de zittingen kunnen worden uitgeoefend door een College van Gedelegeerden, bestaande uit de voorzitter van de Raad en twintig door de Raad op basis van evenredige vertegenwoordiging uit zijn midden gekozen leden.

Wat de samenstelling van de Volksraad betreft, had het voorstel van de regering voorzien in 30 Indonesische en 25 à 27 Nederlandse leden, naast de leden uit andere groepen en de voorzitter. De rechtse meerderheid in de Tweede Kamer veranderde deze verhouding: volgens de nieuwe wet zou de Volksraad 25 Indonesische en 30 à 32 Nederlandse leden tellen.

\section{De Ondernemersraad voor Nederlandsch-Indië en de Utrechtse indologenopleiding}

Indonesië was voor de daar werkende westerse ondernemingen in de eerste plaats een land van goedkope grondstoffen en zeer goedkope arbeidskrachten. Die ondernemingen hadden dan ook rechtstreeks belang bij het beleid van de overheid, onder meer bij zo licht mogelijke fiscale lasten en medewerking bij het tegengaan van werkweigering (zoals door de poenale sanctie). Al sinds de negentiende eeuw organiseerden verschillende groepen ondernemingen zich in grote verbanden voor de gemeenschappelijke behartiging van hun belangen. Ook beheersten zij een deel van de Nederlandstalige pers in de kolonie. Als overkoepelende organisaties vormden zij in de twintigste eeuw de Indische Ondernemersbond in Batavia en de Ondernemersraad voor Nederlandsch-Indië in Den Haag.

Uit het gezichtspunt van de ondernemersbelangen hield de opkomende Indonesische beweging een ernstige bedreiging in. M.W.F. Treub, die in 1921 voorzitter van de Ondernemersraad werd, leverde daarom zware kritiek op de ethische koers in het koloniaal beleid. Daarmee kwam hij lijnrecht tegenover de hoogleraren van de Leidse indologenopleiding te staan, die juist in deze jaren die koers met vuur verdedigden, onder meer in verband met het debat over de herziening van de Nederlands-Indische staatsinrichting. Snouck Hurgronje duidde het koloniale bewind in 1923 zelfs aan als 'een verderfelijk stelsel, dat dagelijks ten hemel schreiend onrecht baart'. Ook beschuldigde hij de Nederlanders van hypocrisie, omdat ze graag blijk gaven van machteloze verontwaardiging over onrecht dat in andere landen plaatsvond terwijl ze geen aandacht schonken aan het onrecht in Nederlands-Indië, waar ze niet machteloos tegenover stonden maar zelf verantwoordelijk voor waren.

De Leidse hoogleraren werden om hun kritische uitspraken zwaar aangevallen, onder andere door F.C. Gerretson. Treub vond dat ze de toekomstige bestuursambtenaren geen begrip bijbrachten voor de goede gevolgen van de westerse investeringen voor de ontwikkeling van Indonesië. In 1924 lanceerde hij een plan voor het stichten van een concurrerende indologenopleiding aan 
de universiteit in Utrecht. Vooral de grote suiker- en handelsondernemingen en de Bataafsche Petroleum Maatschappij brachten daarvoor de nodige gelden bijeen. Colijn, die destijds minister van financiën was, steunde het plan binnen de regering. In oktober 1925 werd de Utrechtse indologiefaculteit geopend; veertien bijzondere hoogleraren waren er aan verbonden. Gerretson kreeg een leerstoel voor de geschiedenis en de vergelijkende volkenkunde van Nederlands-Indië. Hij was de spil en de ziel van de opleiding, die door haar tegenstanders de 'oliefaculteit' werd genoemd.

\section{Studenten in Nederland; de Perhimpoenan Indonesia}

De vereniging van Indonesische studenten in Nederland, die sinds 1922 Indonesische Vereeniging heette, kreeg in deze jaren een volledig politiek karakter. Met ingang van 1924 noemde zij haar blad Indonesia Merdeka (wat zowel 'Vrij Indonesië' als 'Indonesië vrij' betekent). In datzelfde jaar gaf zij ter gelegenheid van haar vijftienjarig bestaan een gedenkboek uit, verlucht met een roodwitte vlag en een portret van Diponegoro, waarin zij zich in onverzoenlijke termen tegen het Nederlandse kolonialisme keerde. In 1925 besloot zij de Maleise versie van haar naam, Perhimpoenan Indonesia (PI), voortaan als officiële naam te gebruiken.

In verschillende artikelen en beginselverklaringen zette de vereniging haar politieke lijn uiteen. Zij duidde het einddoel aan als nationale onafhankelijkheid, zowel in politieke als in economische zin. Het laatste hield in dat Indonesië niet meer zou worden uitgebuit door uitheems kapitaal. Het onafhankelijke Indonesië zou een democratische, aan het volk zelf verantwoordelijke regering moeten krijgen. De vereniging zag massa-actie als het middel om de onafhankelijkheid te bereiken. $\mathrm{Zij}$ riep op tot hechte aaneensluiting van alle Indonesiërs, met terzijdestelling van onderlinge groepsverschillen. Ook verkondigde zij dat men moest steunen op eigen kracht en kundigheid, niet op de hulp van anderen. De vereniging sprak zich met nadruk uit voor de non-coöperatiepolitiek. Zij betoogde dat de belangentegenstelling tussen de overheerser en de overheerste het essentiële element is van iedere koloniale verhouding. Men zou de neiging van de overheerser naar verdoezeling en maskering van dit element moeten beantwoorden met verscherping en accentuering van alle tegenstellingen.

De Indonesische Vereeniging/Perhimpoenan Indonesia was de eerste politieke organisatie van Indonesiërs op zuiver nationalistische grondslag. Dat zulk een organisatie juist in Nederland van de grond kwam, hing samen met het feit dat de Indonesische studenten hier maar een kleine groep vormden, dat zich onder hen zowel moslims als christenen bevonden en dat zij niet alleen uit Java maar ook uit andere delen van de archipel afkomstig waren. 
Voor hun vertrek hadden deze studenten al in Indonesië de opkomst van de emancipatiebeweging meegemaakt. In Nederland werd hun politieke bewustwording bevorderd door het contrast van de situatie in hun geboorteland met de bijna onbegrensde politieke vrijheid in hun land van verblijf en het daar ontbreken van een maatschappelijke tweedeling op basis van ras. Ook werden zij beïnvloed door de successen die verscheidene Europese vrijheidsbewegingen na de Wereldoorlog behaald hadden, waardoor landen als Finland, Polen, Tsjechoslowakije en Ierland onafhankelijk waren geworden.

Hoewel de Perhimpoenan Indonesia maar een kleine vereniging was, heeft zij de politieke ontwikkeling in Indonesië zelf aanzienlijk beïnvloed, onder meer omdat veel van haar vooraanstaande leden daar na terugkeer een leidende rol in de nationale beweging gingen spelen. De invloedrijkste figuur binnen de vereniging was Mohammad Hatta. Hij was geboren in 1902, behoorde tot een Minangkabause familie van handelaren en moslimvoorgangers en was actief geweest in de Jong-Sumatranen Bond. Van 1922 tot 1932 studeerde hij economie in Rotterdam; gedurende die tien jaar wijdde hij een groot deel van zijn tijd aan politiek werk. Het initiatief tot de radicalisering van de vereniging was niet van hemzelf uitgegaan, maar hij stond er volledig achter. In 1923 kwam hij in het bestuur, in 1926 werd hij voorzitter. Tijdens zijn studiejaren leerde hij niet alleen Nederland kennen, maar reisde hij ook veel in andere Europese landen.

Eén van Hatta's doelstellingen was te bevorderen dat in Indonesië zelf een nationalistische partij tot stand zou komen. Hij meende dat zo'n partij zich in de eerste plaats zou moeten richten op de vorming van geschoold kader en pas daarna op het organiseren van de volksmassa's. Een massale aanwas die bijna even snel weer verdween als ze gekomen was, zoals die van de Sarekat Islam, leek hem niet doelmatig.

De vereniging in Nederland werd zelf meer en meer een strak geleide politieke strijdgroep. Al in 1924 royeerde zij haar vroegere voorman Noto Soeroto, nadat deze in een artikel positieve opmerkingen had gemaakt over de in dat jaar overleden Van Heutsz. Daarna royeerde de vereniging nog herhaaldelijk leden die zich niet aan haar politieke lijn hielden. Voortaan hadden de leden toestemming van het bestuur nodig als zij in woord of geschrift in het openbaar wilden optreden. Een aantal Indonesische studenten wendde zich van de PI af, omdat deze politisering hun niet aanstond. Bovendien begon de Nederlandse overheid zich tegen de vereniging te keren, onder meer door beursstudenten te bedreigen met intrekking van hun beurs als zij in de PI actief bleven.

De door de PI ingeslagen koers bracht met zich mee, dat haar politieke contacten met Nederlandse groeperingen zich in hoofdzaak richtten op de socialistische en de communistische beweging, want alleen de hiertoe behorende partijen erkenden een Indonesisch recht op onafhankelijkheid. Daarbij ver- 
klaarde de grootste van die partijen, de SDAP, zich echter tegen onmiddellijke verlening van onafhankelijkheid, in tegenstelling tot de communisten, die de leuze 'Indië los van Holland nu!' hanteerden. Verder oefenden de verbannen PKI-leiders Tan Malaka en Semaoen tijdens hun verblijf in Nederland invloed uit binnen de kring van de PI.

Hatta onderschreef in grote lijnen de marxistische analyse van het moderne kolonialisme als een uitvloeisel van het kapitalistische stelsel. Hij sloot zich niet bij de communistische beweging aan (onder meer omdat het daar dominerende atheïsme hem als overtuigd moslim tegenstond), maar was wel bereid ermee samen te werken. In februari 1927 nam de PI deel aan de oprichting van een internationale Liga tegen Imperialisme en Koloniale Onderdrukking, die haar ontstaan dankte aan een initiatief van de Komintern. Hatta werd lid van het Liga-bestuur, samen met onder meer de Indiase politicus Jawaharlal Nehru.

De samenwerking van de PI met de communistische beweging sterkte sommige Nederlandse autoriteiten in hun overtuiging dat de PI een revolutionaire organisatie geworden was. In juli 1927 verrichtte de politie huiszoekingen bij een aantal PI-leden; twee maanden later arresteerde zij Hatta en drie andere PI-leiders. Ondanks de verkoelde verhouding tussen de PI en de SDAP zorgde deze partij voor hun verdediging door een advocaat die parlementslid voor de SDAP was. In maart 1928 sprak de Haagse rechtbank de vier verdachten vrij. De arrestatie en berechting van deze studentenleiders kregen zowel in Nederland als in Indonesië veel publiciteit en vergrootten het prestige van de PI. Hatta publiceerde de verdedigingsrede die hij voor de rechtszitting had opgesteld als een ruim tachtig pagina's tellende brochure onder de titel Indonesië vrij!

Na zijn invrijheidstelling wijdde Hatta zich meer aan de voortzetting van zijn studie dan aan de PI, al bleef hij nog actief in de internationale Liga tegen Imperialisme en Koloniale Onderdrukking. De oude garde van de PI was intussen naar Indonesië teruggekeerd; verscheidene nieuwe leiders stonden sterk onder communistische invloed. Binnen de vereniging vond Hatta wel een geestverwant in de zeven jaar jongere Minangkabauer Sjahrir (met zijn Minangkabause titel meestal Soetan Sjahrir genoemd), die in 1929 in Nederland rechten kwam studeren. Hatta en Sjahrir konden echter niet beletten dat de leiding van de PI zich volledig op Moskou ging oriënteren, met het gevolg dat zij eind 1931 zelf uit de vereniging geroyeerd werden. Sjahrir keerde kort daarna naar Indonesië terug. In augustus 1932 keerde ook Hatta terug, nadat hij zijn doctoraalexamen economie had afgelegd.

De Perhimpoenan Indonesia had in de jaren dertig minder invloed dan in het verleden. De meeste Indonesische studenten in Nederland gaven er de voorkeur aan zich in ander verband te organiseren. Bovendien nam het aantal in Nederland studerenden af, omdat er meer hoger onderwijs in Indonesië zelf gegeven werd, terwijl het gouvernement geen beurzen voor studie in 


\title{
INDONESIË VRIJ!
}

\author{
ONUITGESPROKEN, AAN DE RECHTBANK \\ OVERGELEGDE, REDE, TER VERDEDIGING \\ VAN DE „PERHIMPOENAN INDONESIA" \\ NAAR AANLEIDING VAN HET PROCES \\ TEGEN DE INDONESISCHE STUDENTEN
}

DOOR

\section{MOHAMMAD HATTA}

\author{
MET EEN VOORWOORD VAN \\ EDO FIM MEN
}

DEN HAAG „PERHIMPOENAN INDONESIA" - 1928

Hatta (1902-1980) stond in 1928 in Den Haag terecht en legde toen aan de rechtbank een in gevangenschap geschreven pleitrede over met een principiële uiteenzetting van het doel en streven van de door hem geleide vereniging Perhimpoenan Indonesia. $\mathrm{Na}$ zijn vrijspraak is die rede als een brochure van 80 pagina's gepubliceerd. 
Nederland meer toekende, nu veel vroegere beursstudenten daar tegenstanders van het koloniale bestuur geworden waren.

\section{De studieclubs van Soetomo en Soekarno}

De Indonesische emancipatiebeweging was omstreeks 1924 ernstig verbrokkeld. Er was een eind gekomen aan de samenwerking tussen Indonesische en Nederlandse groeperingen die in 1922 onder meer geleid had tot het Comité voor Autonomie voor Indië. Het streven van Douwes Dekker en de zijnen naar een nationalistische organisatie op multiraciale grondslag was mislukt. De PKI en de Sarekat Islam hadden zich de laatste jaren vooral beziggehouden met het bestrijden van elkaar. Het gouvernement liet weinig ruimte meer voor politieke activiteiten.

In deze situatie nam Soetomo, die in 1908 aan de wieg van Boedi Oetomo had gestaan en later in Nederland voorzitter van de Indonesische studentenvereniging was geweest, het initiatief tot een nieuwe organisatievorm. In Soerabaja, waar hij docent op de artsenschool was, richtte hij in juli 1924 de Indonesische Studieclub op, bedoeld voor het bestuderen van politieke en sociale kwesties ten behoeve van de vorming van leiders en de voorlichting van de bevolking. Naar dit voorbeeld kwamen ook in andere steden op Java studieclubs tot stand. De belangrijkste daarvan was de eind 1925 opgerichte Algemeene Studieclub in Bandoeng. Terwijl de leiding van deze clubs grotendeels bij oud-leden van de Perhimpoenan Indonesia berustte, kreeg de Bandoengse studieclub als eerste secretaris een man die nog nooit buiten Java geweest was, de student Soekarno.

Soekarno was op 6 juni 1901 geboren als zoon van een Javaan en een Balinese. Zijn moeder kwam uit een hindoeïstische familie en was pas na haar huwelijk tot de islam overgegaan. Zijn vader, een onderwijzer, was geen orthodoxe moslim maar behoorde tot de theosofische beweging. Nadat Soekarno een ILS had doorlopen en nog een jaar op een ELS had gezeten, bezocht hij van 1916 tot 1921 de HBS in Soerabaja. Omdat zijn ouders daar toen niet woonden, werd hij ondergebracht in een kosthuis dat werd gedreven door de vrouw van Tjokroaminoto. Dit kosthuis was ook een trefpunt voor Indonesische nationalisten, zodat Soekarno in deze jaren niet alleen Tjokroaminoto maar ook andere belangrijke politici leerde kennen. Hij ging dikwijls mee wanneer Tjokroaminoto bijeenkomsten toesprak. Zelf was hij in die tijd lid van de met Boedi Oetomo gelieerde vereniging Jong Java en nam hij deel aan een beweging voor afschaffing van het kastenstelsel in de Javaanse taal. Hij wilde na zijn eindexamen in Nederland gaan studeren, maar zijn moeder maakte daar bezwaar tegen. Daarom schreef hij zich in 1921 in aan de één jaar eerder geopende Technische Hogeschool in Bandoeng. Intussen was de echtgenote 
van Tjokroaminoto overleden en was Soekarno met diens dochter getrouwd. Toen Tjokroaminoto zelf in 1921 gearresteerd werd, keerde Soekarno naar Soerabaja terug om de zorg voor diens gezin op zich te nemen; pas een jaar later, na Tjokroaminoto's vrijlating, kon hij zijn studie in Bandoeng opvatten.

In zijn HBS-jaren had Soekarno niet alleen de Javaanse en de islamitische stroming van de nationale beweging leren kennen maar ook de marxistische, die in die tijd binnen de Sarekat Islam veel aanhang kreeg. In Bandoeng kwam hij in nauwere aanraking met de nationalistische stroming, van wie enkele pioniers daar toen woonden: Abdoel Rivai (die voor de Sumatranenbond in de Volksraad zat), Douwes Dekker en Tjipto Mangoenkoesoemo. Soekarno had veel waardering voor Douwes Dekker en gaf enige tijd les op diens Ksatrian Instituut, maar Tjipto werd nu zijn voornaamste mentor. Soekarno's nationalistische oriëntatie leidde tot een zekere verwijdering met Tjokroaminoto, die zich onder invloed van Agoes Salim steeds meer op de internationale panislamistische beweging richtte; bovendien scheidde Soekarno van diens dochter. Tjipto bekeerde hem tot de non-coöperatiepolitiek. Toen Soekarno in mei 1926 zijn ingenieurstitel behaalde, wilde hij dan ook geen overheidsbetrekking aannemen en begon hij een particulier ingenieursbureau.

De Studieclubs in Soerabaja en Bandoeng verschilden van karakter. De Soerabajase studieclub gaf veel aandacht aan sociale problemen, bevorderde de stichting van scholen, vakbonden en een kredietbank en behandelde de non-coöperatiepolitiek als een tactische kwestie. De Bandoengse studieclub was vooral gericht op politieke actie, in nauwe aansluiting bij de opvattingen van de Perhimpoenan Indonesia, en zag non-coöperatie als een beginsel. Soekarno werd na zijn afstuderen de feitelijke leider van de club en ging krachtig propaganda maken voor het Indonesisch nationalisme.

\section{Mislukte communistische opstand}

Nadat het gouvernement Tan Malaka en Semaoen uit Indonesië verwijderd had, raakte de PKI meer en meer op drift. Hoewel haar aanhang sterk toenam, vooral in Bantam (West-Java) en Minangkabau, telde zij onder haar leden maar weinig ontwikkelden. Tot die laatsten behoorden wel twee nieuwe leiders die in 1924 lid van het bestuur werden, Alimin en Moeso. Alimin was in zijn jeugd door Hazeu (die toen Javaans doceerde) als pleegzoon aangenomen, had Europees onderwijs gevolgd, was journalist geworden en had een rol gespeeld in Boedi Oetomo, Insulinde, de ISDV en vooral in de Sarekat Islam. Moeso was eveneens een prominent SI-lid geweest. Van 1920 tot 1923 hadden Alimin en Moeso gevangen gezeten wegens de Afdeling B-affaire. Na hun gevangenschap keerden zij zich van de SI af en traden zij toe tot de PKI. Het gouvernement dreef sinds de spoorwegstaking van mei 1923 de PKI en 
de met haar verbonden vakbonden steeds meer in het nauw. De partijleiding voorzag dat de PKI niet lang als legale partij zou kunnen blijven bestaan. De partijleden waren revolutionair gestemd; zij wilden actie ter verdrijving van de westerse overheersers, niet in een verre toekomst maar op korte termijn. De partij besloot nu een clandestiene organisatie op te bouwen en een opstand voor te bereiden.

Tan Malaka, die als Komintern-agent voor Zuidoost-Azië afwisselend in China, de Filippijnen en Achter-Indië verbleef, probeerde herhaaldelijk de koers van de PKI te veranderen. Daartoe liet hij onder meer in april 1925 in Kanton een Nederlandstalige brochure drukken onder de titel Naar de 'Republiek-Indonesia'. Hij zette hierin uiteen hoe het Indonesische volk zich langs revolutionaire weg zou kunnen bevrijden van het koloniale juk. Daartoe zou de PKI zich niet alleen moeten richten op de arbeiders, maar ook de steun moeten verwerven van de boerenbevolking en de kleine burgerij. Er zou nog veel moeten gebeuren voordat een greep naar de macht zou worden gedaan. De dan te stichten Republiek Indonesia zou een federatieve republiek van de verschillende eilanden moeten worden; ook de Filippijnen zouden er deel van moeten uitmaken. Wat de internationale situatie betreft, deelde Tan Malaka de verwachting dat een oorlog tussen Japan en de Verenigde Staten op de duur onvermijdelijk was, maar het was onzeker of die oorlog aan Indonesië de onafhankelijkheid zou brengen. Het zou onjuist zijn de revolutionaire actie te koppelen aan het onbekende tijdstip van het uitbreken van een Pacific-oorlog.

Een nieuwe stakingsgolf in de tweede helft van 1925 leidde tot verder ingrijpen van het gouvernement. De PKI kreeg een vergaderverbod, een deel van de partijleiding werd gearresteerd. Alimin en Moeso vluchtten naar Singapore. Darsono, die tot de gearresteerden behoorde, werd op dezelfde voet als Semaoen uit Indonesië verbannen. Op 25 december kwamen elf nog op vrije voeten verkerende PKI-leiders bijeen bij de tempels van Prambanan (ten oosten van Jogjakarta). Zij besloten dat in 1926 tot opstand zou worden overgegaan. Die opstand zou moeten beginnen in Minangkabau; wanneer dan een deel van het koloniale leger daarheen zou zijn gegaan, zou vervolgens heel Java in opstand komen.

Het duurde enige maanden voordat het besluit van Prambanan aan Tan Malaka bekend werd. Hij zag het als een stap naar zelfvernietiging en ondernam verschillende pogingen om het ongedaan te maken. Alimin en enige andere leiders die aan het besluit vast wilden houden gaven zijn bezwaren niet aan de partij door. De partij stuurde Alimin en Moeso op reis om steun van de Komintern voor de opstand te verwerven. In de zomer wees de Komintern het opstandplan volstrekt af. Vergeefs probeerden Alimin en Moeso in Moskou maandenlang alsnog Komintern-steun te krijgen. Intussen werd de situatie in Indonesië steeds verwarder. Het gouvernement had lucht gekregen van de opstandplannen, nam het partij-archief van de PKI in beslag, verbood alle 


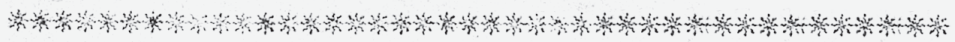

\section{NAAR DE}

\section{"REPUBLIEK-INDONESIA"}

DOOR

\section{T. MALACCA}

Gedrukt eerst Canton April '25.

Herdrukt TOKYO December '25.

Tan Malaka (1897-1949) schreef in 1925, toen hij nog agent voor Zuidoost-Azië van de Communistische Internationale was, een brochure waarvan de titel destijds volkomen irreëel moet hebben geklonken maar die twintig jaar later profetisch bleek te zijn geweest. 
communistische persorganen en verbood alle gouvernementsdienaren om lid van de PKI of de Sarekat Rakjat te zijn. Tan Malaka wist eindelijk een aantal PKI-leiders te overreden het opstandplan op te geven. Maar nu vormden andere PKI-leiders buiten het partijbestuur om in Batavia een revolutionair comité dat het plan toch wilde doorzetten. Hoewel verscheidene partijdistricten, onder andere die van Semarang en Soerabaja, medewerking weigerden, gaf dit comité het parool uit dat de opstand in de nacht van 12 op 13 november moest beginnen.

De opstand werd een volledige mislukking. Het gouvernement kwam nog in de avond van 12 november op de hoogte van het uitgegeven parool, zodat het leger gealarmeerd kon worden. Omstreeks middernacht trokken groepen zwak-bewapende opstandelingen door Batavia; één groep bezette korte tijd de telefooncentrale, een andere probeerde vergeefs een gevangenis te veroveren. Tegen de ochtend was aan alle acties een eind gemaakt en waren ongeveer driehonderd rebellen gevangen genomen. Elders op Java vonden slechts hier en daar revolutionaire acties plaats. Het ernstigste waren die in Bantam, maar binnen enkele weken waren ook daar de acties volledig onderdrukt. In tegenstelling tot het oorspronkelijke plan had de PKI in Minangkabau zich van actie onthouden. Na anderhalve maand van aarzeling kwam zij op 1 januari 1927 alsnog in opstand. De opstandelingen in Minangkabau waren beter bewapend dan die op Java, maar ook hun verzet werd binnen twee weken gebroken.

Dit mislukte avontuur betekende de ondergang van de communistische beweging in Nederlands-Indië. Het gouvernement liet een 13.000 Indonesiërs en Chinezen oppakken van wie werd aangenomen dat ze tot die beweging behoorden. De PKI, de SR-bonden en de communistische vakbonden werden verboden. Van de gearresteerden werden uiteindelijk 7.700 weer vrijgelaten. Ongeveer 4.500 werden berecht en tot gevangenisstraf veroordeeld; dit waren over het algemeen personen die van rechtstreekse betrokkenheid bij gewelddadigheden verdacht werden. Ook werd een aantal doodvonnissen uitgesproken; vier ter dood veroordeelden werden opgehangen; de anderen kregen gratie, tot woede van een deel van de Nederlands-Indische pers. Er bleven nog ruim 800 gearresteerden over, die niet in aanmerking kwamen voor berechting, maar die niettemin als zeer gevaarlijk werden beschouwd. Het gouvernement verbande hen op grond van de exorbitante rechten naar Nieuw-Guinea. Later werd ook een deel van de veroordeelden daarheen verbannen, nadat ze hun gevangenisstraf hadden uitgezeten. Verder brak het gouvernement met het gebruik om aan prominente ballingen toe te staan Indonesië te verlaten.

Na het uitbreken van de PKI-opstand verklaarde de Komintern zich naar buiten toe solidair met de opstandelingen; de Nederlandse communistische partij sloot zich daarbij aan. De communistische propaganda gaf steeds een overdreven voorstelling van de schaal van de opstand.

Toen de opstand begon, waren Alimin en Moeso op terugreis uit Moskou. 
Zij werden in december 1926 in Singapore gearresteerd en enige maanden later door de Britse autoriteiten uitgewezen, verbleven een tijd lang in China en gingen tenslotte weer naar de Sovjetunie.

Tan Malaka brak in 1927 met de Komintern. In Bangkok richtte hij een niet van Moskou afhankelijke communistische partij-in-ballingschap op met de naam Partai Republik Indonesia (Pari). Deze partij kreeg in Indonesië nauwelijks een voet aan de grond.

\section{Boven-Digoel}

Het gouvernement besloot de gevaarlijke communisten die niet wegens de opstand voor berechting in aanmerking kwamen te interneren op een zo afgelegen mogelijke plaats, waar geen communistische invloed hen van buiten zou kunnen bereiken, waar de plaatselijke bevolking door haar lage beschavingspeil onvatbaar zou zijn voor hun denkbeelden en waar men met een minimum aan bewaking zou kunnen volstaan. Het koos daarvoor een plek in het binnenland van Nieuw-Guinea, 450 kilometer stroomopwaarts gelegen aan de rivier de Digoel op 75 kilometer van de grens met het Australische gebied. Met het oog daarop stelde het een district Boven-Digoel in, dat administratief onder de residentie Ambon viel. Het gouvernement besloot bovendien aan gezinsleden van ballingen toe te staan zich bij hen te voegen. Het ging er daarbij van uit dat de uitgekozen streek een gezond klimaat had en zich leende voor rijstbouw, zodat het interneringsoord zich zou kunnen ontwikkelen tot een landbouwkolonie, waarin de ballingen uiteindelijk in hun eigen onderhoud zouden kunnen voorzien. Dit bleek een misvatting. De streek had zwaar te lijden van malaria en de grond was ongeschikt voor rijstbouw.

Nadat op de uitgekozen plek een stuk oerbos was gekapt en enige barakken waren neergezet, werden in de loop van 1927 de eerste groepen ballingen hierheen gebracht. In 1929 waren er in Boven-Digoel ruim elfhonderd geïnterneerden met bijna duizend gezinsleden. In de jaren 1930-1932 werd de internering van ruim zeshonderd ballingen opgeheven. Tegelijk bracht men nieuwe ballingen binnen, waarvan de meesten niet als communisten beschouwd werden. Eind 1939 was het aantal in Boven-Digoel geïnterneerden teruggelopen tot ruim driehonderdvijftig.

Het interneringsoord beschikte over een ziekenhuis, een school, gebedshuizen en een gevangenis. De verbinding met de buitenwereld werd onderhouden door een eenmaal per maand arriverende boot van het gouvernement. De ballingen moesten hun eigen woningen bouwen en hun eigen groente kweken. Hun post werd gecensureerd. Een honderdtal als 'onverzoenlijk' beschouwde ballingen werd geïsoleerd in een speciaal interneringskamp 35 kilometer verder stroomopwaarts aan de rivier. 
Het interneringsoord was niet omgeven met prikkeldraad maar met oerwoud. In de zestien jaar dat het oord bestaan heeft zijn tal van vluchtpogingen ondernomen, maar geen daarvan is geslaagd. Sommige vluchtelingen kwamen om in de bossen en de moerassen, anderen werden gedood door de schaarse Papoeabevolking. Allen die er in slaagden Australisch gebied te bereiken, werden door de Australische autoriteiten uitgeleverd en naar Boven-Digoel teruggebracht, waar ze vervolgens gevangenisstraf kregen voor hun vluchtpoging.

\section{De vertrouwenspolitiek van De Graeff}

In september 1926 werd gouverneur-generaal Fock opgevolgd door A.C.D. de Graeff, die vroeger de rechterhand van gouverneur-generaal Van Limburg Stirum geweest was en diens opvattingen deelde. Zijn benoeming viel dan ook slecht bij de meeste Nederlanders in de kolonie. Naar zijn mening moest men onderscheid maken tussen revolutionaire en constructieve politieke bewegingen. Terwijl hij bereid was de eerste hard aan te pakken, zoals bleek uit zijn reactie op de communistische opstand, wilde hij de tweede welwillend tegemoettreden. Al kort na zijn aantreden verklaarde hij dat hij zich zou inspannen om de aanhangers van de non-coöperatiegedachte tot ander inzicht te brengen en om iedere aanleiding weg te nemen en te vermijden die aan non-coöperatie een schijnbaar redelijke grondslag zou kunnen geven. Hij meende dat het vertrouwen van de constructieve Indonesische nationalisten onder meer geschokt was door het besluit van het Nederlandse parlement om van de 61 Volksraadzetels slechts 25 voor Indonesiërs te bestemmen in plaats van 30 zoals de regering oorspronkelijk had voorgesteld. Daarom drong hij er bij de regering op aan te proberen dit besluit terug te draaien.

In dezelfde geest maakte De Graeff in het voorjaar van 1927 gebruik van zijn bevoegdheid tot het aanwijzen van leden voor de nieuwe Volksraad. Niet alleen benoemde hij enige Nederlanders die zich positief tegenover het Indonesisch nationalisme opstelden, onder wie J.A. Jonkman, maar ook bood hij de nationalistische leiders Tjokroaminoto en Soetomo zetels aan. Tjokroaminoto wees zijn benoeming meteen af. Soetomo raadpleegde zijn Studieclub en besprak de zaak met De Graeff zelf, maar weigerde uiteindelijk ook. In zijn plaats benoemde De Graeff de zakenman Mohammad Hoesni Thamrin, wethouder van Batavia en leider van de Kaoem Betawi, een organisatie voor de Indonesische bevolking van de hoofdstad.

Intussen wekte het beleid van De Graeff zo veel vertrouwen bij Tjipto Mangoenkoesoemo, dat deze pionier van de non-coöperatiepolitiek zich kandidaat liet stellen bij de verkiezingen voor de Volksraad. Hij kon zijn Volksraadzetel echter niet innemen, omdat hij onder verdenking kwam te staan nadat hij contact had gehad met enige militairen die een opstand wilden 
beginnen. De PID beschouwde hem als één van de gevaarlijkste Indonesische politici. In december interneerde De Graeff hem op de Banda-eilanden.

\section{De eerste nationalistische massabeweging: Soekarno's PNI}

De uitschakeling van de communistische beweging en de verzwakking van de Sarekat Islam schiepen ruimte voor de ontplooiing van een nieuwe Indonesische organisatie op zuiver nationalistische grondslag. Daar kwam ook meer ruimte voor door het beleid van gouverneur-generaal De Graeff. Intussen was de voorbereiding van een nieuwe nationalistische organisatie al voor de aankomst van De Graeff begonnen. Uit Nederland teruggekeerde leden van de Perhimpoenan Indonesia hadden daartoe in de zomer van 1926 in Bandoeng en enige andere steden comités opgericht. Het Bandoengse comité was nauw verbonden met de Bandoengse Studieclub en werd gedomineerd door ir. Soekarno en mr. Sartono, een jurist die met Hatta in het bestuur van de Perhimpoenan Indonesia gezeten had. Anders echter dan Hatta, die meende dat de nieuwe organisatie zich eerst alleen op kadervorming zou moeten richten en nog niet op het mobiliseren van de massa's, vonden Soekarno en Sartono dat men zowel het één als het ander moest doen.

Eind 1926 zette Soekarno zijn politieke denkbeelden in enige tijdschriftartikelen uiteen. Hij betoogde dat de drie stromingen binnen de Indonesische beweging - de islamitische, de marxistische en de nationalistische - niet onderling tegenstrijdig waren. Belangrijker dan hun verschilpunten was het doel dat ze alle drie nastreefden: het beëindigen van de koloniale overheersing. Ze zouden dan ook over hun verschillen moeten heenstappen en een gezamenlijk front tegen de overheersers moeten vormen. Zonder nationale eensgezindheid zou de onafhankelijkheid niet worden bereikt. Daarom was het van belang de nationale geest van de Indonesiërs aan te wakkeren.

Leden van het Bandoengse comité stichtten op 4 juli 1927 de Perserikatan Nasional Indonesia (Indonesische Nationale Vereniging), met Soekarno als voorzitter. Volgens haar statuten streefde deze nieuwe organisatie naar de onafhankelijkheid van Indonesië; ook verder stemde haar politieke ideologie overeen met die van de Perhimpoenan Indonesia. Naast politieke had zij sociale en economische programmapunten, die onder meer voorzagen in bestrijding van analfabetisme en woeker en in oprichting van scholen, coöperaties en poliklinieken. De vereniging hield haar eerste congres in mei 1928 en werd bij die gelegenheid omgedoopt in Partai Nasional Indonesia (PNI).

Men bouwde de organisatie zeer voorzichtig op, waarbij men onder meer probeerde zowel spionnen van het koloniale bestuur als oud-leden van de PKI te weren. Kandidaat-leden moesten een proeftijd van drie maanden doormaken voordat ze lid konden worden; ook de vorming van plaatselijke afdelingen 
was aan strikte voorwaarden gebonden. De PNI organiseerde basiscursussen voor hen die tot de partij wilden toetreden; daarnaast hield zij kadercursussen om toegelaten leden voor te bereiden voor leidende functies. Eind 1928 telde de partij nog geen 2800 leden. Daarna ging de groei iets sneller; tegen het eind van 1929 had zij ongeveer tienduizend leden. De PNI-afdeling in de hoofdstad noemde zich 'afdeling Djakarta'; dit was de eerste maal dat men weer de oude naam gebruikte in plaats van het Nederlandse 'Batavia'.

De zorgvuldige opbouw van de organisatie beantwoordde geheel aan de denkbeelden van Hatta, maar de PNI deed méér. Zij hield tal van openbare bijeenkomsten om haar visie onder het grote publiek te verbreiden, zonder dit onmiddellijk aan ledenwerving te koppelen. De belangrijkste spreker was altijd Soekarno. Nog veel meer dan zijn leermeester Tjokroaminoto verstond hij de kunst een massapubliek in zijn ban te brengen. Bovendien kende hij de voorstellingswereld van de Javaanse bevolking beter dan de politici die in Nederland gestudeerd hadden; hij knoopte in zijn toespraken graag aan bij bekende wajangverhalen. Hij beklemtoonde steeds, dat de koloniale overheersers zich uit eigenbelang van Indonesië meester hadden gemaakt en het nooit vrijwillig zouden prijsgeven. Hij riep op tot nationale eenheid en verkondigde keer op keer, dat de nationale geest moest leiden tot de nationale wil en uiteindelijk tot de nationale daad.

Gedurende het eerste jaar van het bestaan van de PNI gaven enige onverwachte gebeurtenissen aanleiding tot het organiseren van bijzondere manifestaties. In de zomer van 1927 waren dat eerst de huiszoekingen in Nederland bij voormannen van de Perhimpoenan Indonesia en vervolgens hun gevangenneming. In december was het de verbanning van Tjipto Mangoenkoesoemo naar de Banda-eilanden. Tenslotte leidde de vrijspraak van Hatta en zijn vrienden in maart 1928 tot nieuwe manifestaties, nu niet van protest maar van triomf.

Soekarno en zijn medestanders keerden zich niet alleen tegen de koloniale overheersing, maar ook tegen het inheemse feodalisme. Zij gaven hier uitdrukking aan door niet langer de traditionele Indonesische hoofddoek te dragen. In plaats daarvan droegen zij een rechte muts van zwart velours, die nu het symbool van de radicale nationalisten werd.

De nationalistische voormannen wilden in de jaren 1926-1927 niet alleen een eigen organisatie oprichten, maar ook een toenadering teweegbrengen tussen de bestaande groeperingen binnen de nationale beweging. Soekarno slaagde zowel op het eerste als op het tweede punt. In december 1927 kwam een federatie tot stand onder de naam Permoefakatan Perhimpoenan-Perhimpoenan Politik Kebangsaan Indonesia (PPPKI, Verbond van de Politieke Verenigingen van de Indonesische Natie). Hieraan namen deel: Boedi Oetomo, de Sarekat Islam, de PNI, de Soerabajase Studieclub, de Sumatranenbond, de Soendanese vereniging Pasoendan en de Bataviase vereniging Kaoem Betawi. Het was een zeer losse organisatie, die alleen met eenstemmigheid besluiten kon nemen en 
dan ook weinig eigen activiteiten aan de dag legde. Maar het belangrijke punt was dat alle deelnemende groeperingen, met inbegrip van Boedi Oetomo, nu uitdrukkelijk de doelstelling van Indonesische onafhankelijkheid onderschreven. Tegelijk waren ze overeengekomen, dat de PPPKI geen standpunten zou innemen over religieuze kwesties en over de kwestie van coöperatie tegenover non-coöperatie. Soetomo werd voorzitter van de federatie.

De totstandkoming van deze federatie was mogelijk, omdat oud-leden van de Perhimpoenan Indonesia nu zowel in Boedi Oetomo als in de Sarekat Islam belangrijke posities innamen. Een cruciale rol speelde Soekiman Wirjosandjojo, een arts in Jogja die in Nederland voorzitter van de PI geweest was. Hij leide nu de jonge garde in de SI en wist daar de weerstanden van Tjokroaminoto en Agoes Salim te overwinnen. Samen met Soekarno bereidde hij de federatie voor.

Intussen zag de Sarekat Islam zijn positie als leidende islamitische organisatie steeds verder afbrokkelen. Een deel van zijn leden vloeide weg naar de Moehammadiah, welker moderne islamitische opvattingen door velen binnen de SI werden gedeeld. Anderzijds riep de hervormingsgezinde stroming binnen de islam ook reacties onder de traditionele stroming op. Conservatieve moslimvoorgangers stichtten in 1926 een eigen organisatie, de Nahdatoel Oelama (Opleving der Schriftgeleerden), die zich gezagsgetrouw opstelde en al snel een grote aanhang kreeg.

\section{Het Indonesisch Jeugdcongres van 1928}

In dezelfde periode waarin de PNI en de federatie PPPKI tot stand kwamen, manifesteerde het streven naar nationale eenheid zich ook binnen de Indonesische jeugdorganisaties. De meeste van die organisaties berustten op etnische grondslag; de oudste en grootste daarvan was Jong Java. Intussen waren daarnaast ook organisaties gevormd die zich niet tot een etnische groep beperkten. Op aansporing van Agoes Salim was eind 1924 een JongIslamieten Bond opgericht. In 1926 stichtten studenten aan de hogescholen in Batavia en Bandoeng de Perhimpoenan Peladjar-Peladjar Indonesia (PPPI, Vereniging van Indonesische Studenten). Verder werd in 1927 onder auspiciën van de Bandoengse studieclub een nationalistische jeugdorganisatie gevormd, Pemoeda Indonesia (Indonesische Jongeren).

De studentenvereniging PPPI, wier politieke visie nauw aansloot bij die van de Perhimpoenan Indonesia, werd het kweekbed voor een nieuwe generatie leiders van de nationale beweging. Twee hiervan waren Amir Sjarifoeddin en Mohammad Yamin, die beiden in Batavia rechten studeerden. Sjarifoeddin, een Batakse moslim die in Nederland op school geweest was, ontpopte zich als een groot redenaar en organisator. Yamin, een Minangkabauer die 
voorzitter van de Jong-Sumatranen Bond geweest was, werd een bevlogen ideoloog van het Indonesisch nationalisme. In zijn visie zou het toekomstige onafhankelijke Indonesië niet alleen de hele archipel moeten omvatten (met inbegrip van Noord-Borneo en Oost-Timor), maar ook Singapore, Malakka en de Filippijnen.

Op initiatief van een Javaanse journalist vond in 1926 een eerste Indonesisch Jeugdcongres plaats, waar vertegenwoordigers van verschillende jongerenorganisaties met elkaar spraken over samenwerking ter bevordering van de Indonesische eenheid. Van groot belang voor de geschiedenis van Indonesië werd het in 1928 gehouden Tweede Indonesisch Jeugdcongres. Het was georganiseerd door de studentenvereniging PPPI en vond plaats in haar verenigingsgebouw in Batavia. De andere vertegenwoordigde organisaties waren Pemoeda Indonesia, de Jong-Islamieten Bond, Jong Java, Jong Celebes, de Jong-Sumatranen Bond, de Jong-Bataks Bond, de Bataviase jeugdbond en de Soendanese jeugdbond. Enige leiders van de PNI, onder wie Soekarno en Sartono, woonden het congres bij. De jongerenvertegenwoordigers besloten aan hun organisaties voor te stellen om de verschillende bonden te fuseren tot één Indonesisch jongerenverbond.

Op voorstel van Yamin nam het congres op de slotdag, 28 oktober 1928, een plechtige resolutie aan, luidende: 'Wij zonen en dochters van Indonesië erkennen één vaderland te hebben, Indonesië. Wij zonen en dochters van Indonesië erkennen één volk te zijn, het Indonesische volk. Wij zonen en dochters van Indonesië aanvaarden de eenheidstaal, het Indonesisch.' Met het Indonesisch bedoelde men het gemoderniseerde Maleis, dat zich in feite al tot algemene eenheidstaal had ontwikkeld. Deze resolutie is later bekend geworden als de Soempah Pemoeda (Eed van de Jeugd), die jaarlijks op 28 oktober herdacht wordt.

Op hetzelfde congres werd een voor de gelegenheid gedicht en gecomponeerd lied ten gehore gebracht, 'Indonesia Raja' (Groot Indonesië) met vele malen het woord merdeka (vrij, onafhankelijk) in het refrein. Al spoedig werd dit lied bijzonder populair bij de Indonesische nationalisten, die het telkens op hun bijeenkomsten zongen en het de status van een volkslied gaven.

Met uitzondering van de Jong-Islamieten Bond stemden alle op het congres vertegenwoordigde organisaties uiteindelijk in met de voorgestelde fusie. Op 1 januari 1931 gingen ze op in de nieuwe organisatie Indonesia Moeda (Jong Indonesië).

\section{De 'Inlandse meerderheid' in de Volksraad}

In 1927 diende de regering op aandrang van gouverneur-generaal De Graeff een wetsontwerp in, dat voor de samenstelling van de Volksraad terugkeerde 
naar de formule zoals die geluid had voordat het parlement bij amendement slechts 25 in plaats van 30 zetels voor Indonesiërs bestemd had. Het ontwerp voorzag bovendien in uitbreiding van de Raad van Indië van vijf tot zeven leden, teneinde daar ook twee Indonesische leden in op te kunnen nemen. Voorafgaande aan de behandeling van dit wetsontwerp in het parlement moesten eerst de Raad van Indië en de Volksraad er hun oordeel over geven.

Met de nu opnieuw voorgestelde formule voor een (relatieve) 'Inlandse meerderheid' had de Volksraad al in 1922 ingestemd, maar sindsdien was de stemming in de kolonie veranderd. Bovendien werd het nieuwe wetsontwerp na de communistische opstandpoging ingediend, toen de Europese gemeenschap erg gespannen was. Bij de Nederlanders, onder wie de Indische Nederlanders, wekte de formule nu een storm van protest. De campagne tegen de 'Inlandse meerderheid' werd aangevoerd door de president-directeur van de Javasche Bank, L.J.A. Trip, die onverbloemd sprak over de noodzaak 'de inlander eronder te houden'. Ruim twintigduizend personen ondertekenden een door hem opgestelde afwijzing van die formule. De voorgestelde uitbreiding van de Raad van Indië ontmoette minder bezwaar.

Het voorstel voor de samenstelling van de Volksraad kreeg in de Raad van Indië onvoldoende steun. Een belangrijke tegenstander was hier Ch.J.I.M. Welter, een voormalig BB-ambtenaar die als lid van de commissie-Carpentier Alting al blijk had gegeven van zijn conservatieve opvattingen, vervolgens de rechterhand van gouverneur-generaal Fock was geweest en in het kabinet-Colijn van 1925-1926 als minister van koloniën was opgetreden. In de Volksraad zelf steunde eind 1927 een ruime meerderheid het regeringsvoorstel. Naast de Indonesische leden stemden elf Nederlandse leden voor, onder wie Jonkman. Zestien Nederlandse leden stemden tegen, onder wie de leden van het IEV en de vertegenwoordiger van de BB-ambtenaren, J.W. Meyer Ranneft. Ook twee Chinese leden stemden tegen.

Zowel de tegenstanders als de voorstanders van de 'Inlandse meerderheid' richtten zich nu op beïnvloeding van het Nederlandse parlement. Hier verloren de tegenstanders uiteindelijk het pleit. De Tweede Kamer aanvaardde het wetsontwerp in 1928 met grote meerderheid; tot de voorstemmers behoorde ook het Kamerlid dat vroeger het initiatief genomen had om het aantal Indonesische zetels te beperken. In de Eerste Kamer ontmoette het ontwerp meer verzet, maar werd het tenslotte in 1929 toch aanvaard. De leider van de ARP, Colijn, behoorde tot de tegenstemmers.

Eind 1929 werden Achmad Djajadiningrat en Koesoemo Joedo tot lid van de Raad van Indië benoemd. De 'Inlandse meerderheid' in de Volksraad werd ingevoerd bij de nieuwe samenstelling in 1931.

Overigens benoemde de regering in 1929 Welter tot vice-president van de Raad van Indië en Meyer Ranneft tot voorzitter van de Volksraad. Welter 
keerde enige jaren later naar Nederland terug, waar hij voorzitter werd van de Ondernemersraad voor Nederlandsch-Indië. Trip werd in 1931 president van de Nederlandsche Bank. Van 1933 tot 1936 was Meyer Ranneft vice-president van de Raad van Indië. Verder verminderde de regering in 1933 het aantal Indonesische leden van deze Raad van twee tot één.

\section{De Vaderlandsche Club}

De campagne tegen de 'Inlandse meerderheid' bereikte haar doel niet, maar leidde wel tot een verdere politisering van de in Indonesië werkende Nederlanders. Daarvan getuigde de snelle groei van een nieuwe organisatie die opkwam voor onverkorte handhaving van het koloniale bestel, de Vaderlandsche Club (VC). Het initiatief hiertoe stamde van een paar journalisten en figuren uit de suikerindustrie in Soerabaja en kreeg veel bijval in de Nederlands-Indische pers. Ten tijde van de officiële oprichting in oktober 1929 had de VC al meer dan zesduizend leden en gaf zij een eigen orgaan uit met een oplaag van tienduizend. Binnen een jaar bereikte zij een omvang van negenduizend leden. Zij ging nu ook als politieke partij optreden. Bij de verkiezingen voor de Volksraad van 1931 verkreeg zij vijf zetels.

De VC was vooral een organisatie van Nederlanders die van plan waren na een loopbaan in de kolonie naar Nederland terug te keren ('trekkers'). Het 'vaderland' waar de naam naar verwees was niet Indonesië, maar Nederland. Terwijl alle eerder door Nederlanders in de kolonie opgerichte politieke partijen (behalve het door Indische Nederlanders gevormde IEV) ook Indonesiërs als lid toelieten, stond het lidmaatschap van de VC alleen voor Nederlanders open.

De VC omschreef haar uitgangspunt in de statuten als volgt: 'De Vaderlandsche Club, zich stellende op den grondslag der onverbreekbaarheid van den band, welke de verschillende delen van het Koninkrijk der Nederlanden tezamen houdt, zooals uitgedrukt in artikel 1 van de Grondwet, heeft ten doel te ageeren tegen alle invloeden, welke dit beginsel aantasten'. De VC spoorde dan ook aan tot hard optreden tegen de Indonesische nationale beweging. Tegelijk richtte zij zich consequent op behartiging van de belangen van de Nederlandse bovenlaag. Zo stelde zij voor geen studiebeurzen meer te verlenen en alle hoger onderwijs in de kolonie af te schaffen, omdat ze de hogescholen op Java als broeinesten van anti-Nederlandse agitatie beschouwde, terwijl ze de functies waar die toe opleidden liever door Europeanen vervuld zag.

De VC vond grote weerklank onder de Nederlandse trekkers, omdat velen daarvan hun toekomst bedreigd zagen door de opkomst van het Indonesisch nationalisme en fel gekant waren tegen de vertrouwenspolitiek van De Graeff. 
Binnen deze kring groeide in die tijd ook waardering voor het Europese fascisme en nationaal-socialisme. Enige jaren na haar oprichting verloor de VC een deel van haar aanhang aan de Nederlands-Indische afdeling van de NSB (de voornaamste nationaal-socialistische organisatie in Nederland). Bovendien nam haar aanhang af omdat aan de vertrouwenspolitiek een vroegtijdig einde kwam, zodat de VC geen oppositie tegen het gouvernement meer behoefde te voeren. Het ledental slonk tot ongeveer tweeduizend, maar nam later weer toe. In de Volksraad behield de VC vier zetels. Tot aan de Japanse tijd bleef de VC de belangrijkste politieke organisatie van de Nederlandse bovenlaag.

\section{Rijkseenheid}

Lange tijd was het 'bezit' van Nederlands-Indië een vanzelfsprekendheid voor de overgrote meerderheid van de Nederlandse bevolking, zowel in de kolonie als in het moederland. In de jaren 1926-1929 werd deze zekerheid verstoord, eerst door de communistische opstanden, daarna door het resolute ageren van de Perhimpoenan Indonesia onder Hatta en de Partai Nasional Indonesia onder Soekarno voor onafhankelijkheid voor Indonesië. In reactie hierop legden meer en meer Nederlanders zich vast op het standpunt, dat noch deze kolonie noch enig ander overzees gebiedsdeel zich van het Nederlandse koninkrijk los zou mogen maken. Zo kwam tegenover de leuze 'Indonesia merdeka' de leuze 'Rijkseenheid' te staan.

Deze koloniale conservatieven behandelden de politieke kwestie van de toekomstige verhouding tussen Nederland en Indonesië bij voorkeur in morele en juridische termen. De manier waarop de Vaderlandsche Club haar uitgangspunt formuleerde was typerend voor hun opstelling. Door de wens tot handhaving van het rijk als een 'beginsel' te presenteren trok men die kwestie in de morele sfeer. Verzaken van dit beginsel door Nederlanders zou gelijk staan aan landverraad. Tegelijk hanteerde men ook tegenover Indonesiërs het juridische argument van een beroep op de Nederlandse grondwet, alsof die universeel geldende normen inhield.

In Nederland vormde de Utrechtse indologiefaculteit het ideologische centrum van de koloniaal-conservatieve richting. Sinds 1929 beschikte die richting over een eigen orgaan, dat een jaar later De Rijkseenheid ging heten. Het openingsnummer bevatte onder meer een artikel waarin betoogd werd dat het Nederlandse volk recht op Indië had, niet alleen krachtens bezit, omdat het er al sinds lang over heerste, maar ook krachtens auteursrecht, omdat het Indië gemaakt had tot wat het was.

De koloniaal-conservatieve richting ontkende het bestaan van een Indonesische natie en verzekerde dat de grote meerderheid van de inheemse bevolking niet naar nationale onafhankelijkheid verlangde. Dit was ook te 
vinden in brochures die Treub en Colijn in 1927 en 1928 publiceerden. Colijn wees Hatta en Soekarno uitdrukkelijk aan als belangrijke nationalistische leiders, maar vond hun beweging 'geenszins een echte volksbeweging, veeleer een actie waar in werkelijkheid slechts een bovenlaagje der bevolking, dun als het zilvervliesje van de rijstkorrel, direct bij betrokken is'. Treub noemde het Indonesisch nationalisme 'ontoelaatbaar' en stelde, dat elke actie die erop gericht was het Nederlandse gezag in Indonesië te ondermijnen zo nodig met geweld onderdrukt moest worden, 'zelfs indien zij een gezonden ondergrond had'.

In de jaren dertig won het koloniaal-conservatisme steeds meer terrein binnen de Nederlandse christelijke en liberale politieke partijen. Terwijl het woord 'rijkseenheid' in 1929 nog niet in hun verkiezingsprogramma's voorkwam, kreeg dit in 1937 uitdrukkelijk een plaats in de programma's van drie van die partijen.

\section{De Stuw-groep}

Dat veel Nederlanders in Indonesië de ethische politiek afwezen betekent niet, dat die politiek daar helemaal geen aanhangers meer had. Enige van deze aanhangers richtten begin 1930 een vereniging op die een veertiendaags tijdschrift ging uitgeven met de naam De Stuw. Het initiatief berustte in hoofdzaak bij hoogleraren van de Rechtshogeschool in Batavia en enkele hoofdambtenaren, onder wie Jonkman en Van Mook. Volgens haar beginselverklaring was de vereniging bedoeld voor Nederlanders die het als hun plicht zagen mee te werken 'aan de verdere uitvoering van Nederland's koloniale taak'; die taak zou voltooid zijn 'wanneer een Indisch Gemeenebest in de rij der zelfstandige volken een eigen plaats inneemt'. Men sprak van een 'Indisch' en niet een 'Indonesisch' gemenebest om aan te geven, dat het niet alleen aan Indonesiërs plaats zou moeten bieden maar ook aan Nederlandse 'blijvers', Indo-Europeanen, Chinezen en Arabieren. Verder streefde men ernaar dat dit gemenebest duurzame banden met Nederland zou onderhouden, maar het zou vrij moeten zijn om hier wel of niet voor te kiezen; men onderschreef dus niet de rijkseenheidsidee. Desgevraagd verklaarde het bestuur zich uitdrukkelijk voor onafhankelijkheid voor het Indisch gemenebest, al liet het zich niet uit over de vraag wanneer men die tegemoet zou kunnen zien. Het tijdschrift De Stuw behandelde voornamelijk politieke en economische onderwerpen. Het bestreed het koloniaal-conservatisme, volgde het werk van de Volksraad en gaf aandacht aan ontwikkelingen in het buitenland die voor de toekomst van Indonesië van belang waren.

De totstandkoming van de Stuw-groep was een reactie op de trend naar rechts binnen de Nederlandse gemeenschap, zoals gebleken uit de opkomst 
van de Vaderlandsche Club. Haar activiteiten leidden soms tot woede in de kringen van de VC en van het Indo-Europees Verbond. De groep telde slechts een paar honderd leden. Tot haar actieve leden behoorden, naast Jonkman en Van Mook, de hoogleraren J.H.A. Logemann en F.M. van Asbeck, de bestuursambtenaar Ch.O. van der Plas en de leraar P.J. Koets. In 1932 werd Logemann voorzitter en Koets secretaris-penningmeester. Hoewel de groep de Indonesische nationale beweging positief tegemoet wilde treden, hadden de meeste leden daar nauwelijks contact mee.

De politieke betekenis van de Stuw-groep was groter dan haar omvang; onder meer hadden enkele van haar leden zitting in de Volksraad. Jonkman verliet de Volksraad in 1931, omdat hij officier van justitie in Makassar werd. In zijn plaats benoemde gouverneur-generaal De Graeff nu Van Mook, een typische vertegenwoordiger van de Nederlandse 'blijvers'. In de Volksraad keerde Van Mook zich stelselmatig tegen achterstelling van de belangen van de kolonie bij die van Nederland.

Ten tijde van haar oprichting stond de Stuw-groep achter de vertrouwenspolitiek van De Graeff. Na diens vertrek in 1931 kwam zij steeds meer tegenover het gouvernement te staan. Het gouvernement zelf was niet gesteld op openlijke kritiek door ambtenaren. De aanhang van de groep liep terug. Enige van haar meest actieve leden konden weinig medewerking meer verlenen omdat zij niet langer in Batavia werkten; het tijdschrift dreef nu grotendeels op de bijdragen van Van Mook. Eind 1933 werd de uitgifte van De Stuw gestaakt en hield ook de vereniging op te bestaan. In het voorjaar van 1934 trok Van Mook zich uit de Volksraad terug.

\section{Het proces-Soekarno}

In 1928 en 1929 ging Soekarno door met het houden van politieke toespraken, zowel in openbare vergaderingen als in besloten bijeenkomsten. De vertrouwenspolitiek van De Graeff beantwoordde hij niet met tegemoetkomendheid. In overeenstemming met de doctrine van de Perhimpoenan Indonesia richtte hij zich juist op verscherping van de tegenstellingen tussen de koloniale overheersers en de overheersten, door hem vaak aangeduid als sana (ginds) en sini (hier). Hij verklaarde dat de Indonesische vrijheidsstrijd deel uitmaakte van een grotere beweging in Azië en dat alle Aziatische nationalisten moesten samenwerken in hun verzet tegen het imperialisme. Om het de Nederlandse ambtenaren moeilijker te maken hem het spreken te beletten, verpakte hij zijn politieke boodschap vaak in beeldspraak, toespelingen en suggestieve vragen.

Eén van Soekarno's favoriete thema's was de 'Pacific-oorlog'. Hoewel Japan in de Wereldoorlog de kant van Groot-Brittannië en Amerika gekozen had, waren sommigen zich al kort na die oorlog gaan afvragen of men niet binnen afzienbare tijd een conflict van deze landen mét Japan moest verwachten. Die 
gedachte leidde onder meer tot speculaties in communistische kring, waar Tan Malakka al in 1925 op gereageerd had in zijn brochure Naar de 'RepubliekIndonesia'. In datzelfde jaar publiceerde een Britse marine-deskundige, Hector Bywater, een spannende toekomstroman onder de titel The Great Pacific War; A history of the American Japanese Campaign of 1931-1933. Hij beschreef daar een oorlog in die zou beginnen met een Japanse verrassingsaanval waarbij onder meer de Amerikaanse Pacific-vloot totaal vernietigd zou worden; het zou de Verenigde Staten veel moeite kosten zich te herstellen, maar na jaren van harde strijd zouden ze toch de overwinning behalen. De mogelijkheid van een Pacific-oorlog kwam nu ook in de Nederlands-Indische pers en in de Volksraad ter sprake. Soekarno gaf in woord en geschrift te kennen dat hij een oorlog tussen Amerika, Groot-Britannië en Japan om de macht in de Pacific onvermijdelijk achtte. In een artikel schreef hij onder meer: ‘Wij kunnen het woeden van de storm nu al horen. [...] Zal ons land niet meegesleept worden in de botsing van de giganten? Laten wij niet onvoorbereid zijn als binnenkort onze vijanden dicht bij ons land en misschien ook binnen onze landsgrenzen een strijd op leven en dood voeren.'

Soekarno knoopte ook graag aan bij een in zijn tijd populaire versie van de Djojobojo-profetie, die voorspelde dat de blanke overheersers zouden worden verdreven door vreemdelingen van gele huidskleur, maar dat het volk van Java kort daarna zijn vrijheid zou herwinnen. Sinds de spectaculaire opkomst van Japan verbreidde zich de veronderstelling, dat die vreemdelingen Japanners zouden zijn. Verder leidde het geloof in de Djojobojo-profetie ertoe, dat sommige Javanen nu in Soekarno de ratoe adil gingen zien.

In zijn toespraken tartte Soekarno het koloniale bestel door onafhankelijkheid te eisen voor het Indonesische volk en door de spot te drijven met de koloniale heersers. Hij bracht daarbij zijn toehoorders in vervoering en raakte ook zelf in vervoering. Zijn optreden werd steeds uitdagender. Verscheidene andere nationalistische leiders vreesden dat deze confrontatiekoers op een botsing met het gouvernement zou uitlopen die de nationale beweging ernstige schade zou kunnen toebrengen. Vanuit zijn ballingsoord Banda drong Tjipto Mangoenkoesoemo er bij Soekarno op aan zich te matigen. Hatta deed hetzelfde vanuit Nederland. Ook onder nationalistische studentenleiders bestond kritiek op Soekarno's optreden. Zij waren teleurgesteld dat hij de uitvoering van het sociale en economische programma van de PNI verwaarloosde en zich vrijwel alleen op politieke agitatie richtte.

Soekarno liet zich noch door adviezen van zijn politieke vrienden noch door waarschuwingen van het gouvernement uit zijn koers brengen. In de loop van 1929 gaf de Nederlands-Indische pers uiting aan toenemende verontwaardiging over de agitatie van de PNI en over de passiviteit van het gouvernement daartegenover. Ook de meeste bestuursambtenaren waren voor krachtig optreden tegen de PNI (die ze voornamelijk als een voortzetting van 


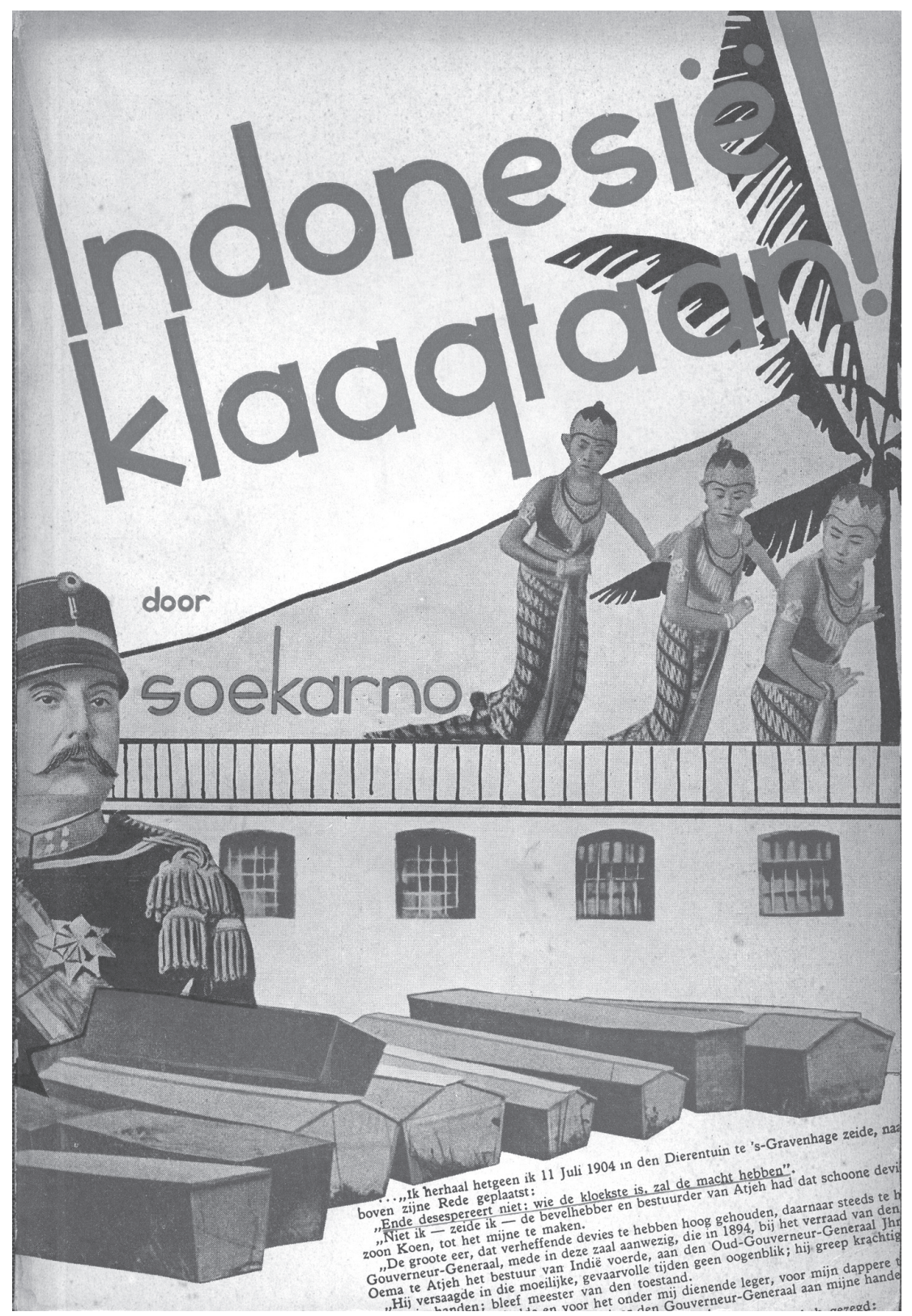

Soekarno (1901-1970) stond in 1930 in Bandoeng terecht en legde toen evenals Hatta een in gevangenschap geschreven principiële pleitrede over, maar anders dan Hatta werd hij tot vier jaar gevangenschap veroordeeld. Zijn rede, die in Indonesië niet in druk kon verschijnen, werd in Nederland door de Arbeiderspers gepubliceerd. 
de PKI zagen), maar gouverneur-generaal De Graeff hield dit lange tijd tegen. Pas toen hem eind december geruchten bereikten over door de PNI geïnspireerde plannen voor omstreeks de jaarwisseling te beginnen opstandige acties, machtigde hij het bestuur om in te grijpen.

Tijdens een razzia in heel Java in de vroege ochtend van 29 december 1929 arresteerde de politie honderden PNI-leiders en -propagandisten en verrichtte zij huiszoekingen in hun woningen en in de PNI-kantoren. De meeste arrestanten werden al gauw weer vrijgelaten, maar Soekarno en drie anderen bleven gevangen. De Graeff verklaarde dat hij dit maal geen gebruik zou maken van zijn exorbitante rechten maar dat het viertal berecht zou worden. De huiszoekingen bleken overigens geen bewijzen op te leveren voor de verdenking van voorbereiding van een opstand. De aanklagers baseerden hun beschuldiging nu in de eerste plaats op een strafbepaling tegen het deelnemen aan een vereniging die het plegen van misdrijven tot oogmerk had, en in de tweede plaats op het in 1926 ingevoerde 'haatzaai-artikel' tegen uitingen waarin, zij het ook zijdelings, voorwaardelijk of in bedekte termen, verstoring van de openbare orde of omverwerping van het gevestigde gezag werd aangeprezen (zie p. 137). Voor de bewijsvoering werd onder meer gebruik gemaakt van aantekeningen uit besloten kadercursussen van de PNI.

Het proces tegen de vier PNI-leden vond in Bandoeng plaats en begon in augustus 1930. Hun verdedigers waren drie Indonesische advocaten (onder wie Sartono) die in Nederland tot de Perhimpoenan Indonesia behoord hadden. In navolging van Sneevliet en Hatta schreef Soekarno een lange verdedigingsrede; het uitspreken daarvan nam twee dagen in beslag. Het einddoel van zijn partij omschreef hij als een 'Federatieve Republiek Indonesië'. In december volgde het vonnis. Soekarno werd veroordeeld tot vier jaar gevangenisstraf met aftrek van voorarrest, de anderen kregen lagere gevangenisstraffen. Nadat het vonnis in april 1931 in hoger beroep was bevestigd, bracht men Soekarno over naar de nieuwe gevangenis in Soekamiskin.

Het vonnis was bijna geheel gewijd aan het eerste punt van de beschuldiging en leek daardoor meer op een veroordeling van de PNI dan van de individuele verdachten. De misdrijven die de PNI volgens de rechters tot oogmerk had waren: opstand en aanslag op de staatsorde, het organiseren van stakingen ter verstoring van de openbare orde en het onrust verwekken onder de bevolking door het verspreiden van een leugenachtig bericht. Het laatste punt baseerden zij op de 'volkomen ongegrondheid' van de voorspelling dat binnenkort een Pacific-oorlog zou uitbreken.

Soekarno's in het Indonesisch uitgesproken verdedigingsrede kon in Indonesië niet in druk verschijnen. In Nederland publiceerde de SDAP een bekorte Nederlandse vertaling onder de titel Indonesië klaagt aan! Daarentegen verscheen in Indonesië wel een door de Stuw-groep uitgegeven brochure die het vonnis aan scherpe kritiek onderwierp en in strijd met de wet noemde. 
Kort voordat gouverneur-generaal De Graeff zijn ambt in september 1931 neerlegde, maakte hij gebruik van zijn recht van gratie om de gevangenisstraf van Soekarno van vier tot twee jaar te verminderen, zodat deze eind december vrij zou komen.

\section{Hergroeperingen binnen de Indonesische nationale beweging}

Het optreden van het gouvernement van eind 1929 tegen de PNI bracht een slag toe aan de non-coöperatieve vleugel van de nationalistische beweging. Eén van de gevolgen daarvan was dat de coöperatieve vleugel van die beweging sterker naar voren trad. Onder de inheemse leden van de Volksraad bevonden zich verscheidene nationalisten, maar die behoorden tot verschillende politieke partijen of waren partijloos. Tien van hen besloten eind januari 1930 te gaan samenwerken als Nationale Fractie. Zij duidden hun doel aan als de zo spoedig mogelijke 'zelfstandigheid' van Indonesië. Fractievoorzitter was Thamrin, een coöperator die ook met non-coöperatieve politici op goede voet stond. Het meest prominente fractielid was de oud-regent Koesoemo Oetojo, voorzitter van Boedi Oetomo en vice-voorzitter van de Volksraad. Later sloot ook de leider van de Soendanese bond Pasoendan, Oto Iskandar Dinata, zich bij de fractie aan. De Nationale Fractie deed in 1932 een verdere stap door haar doel te omschrijven als de zo spoedig mogelijke 'onafhankelijkheid' van Indonesië. Daarmee maakte zij duidelijk dat het verschil tussen de coöperatieve en de non-coöperatieve vleugel van de beweging alleen de methodiek en niet het einddoel betrof. De overige inheemse Volksraadleden onderschreven deze doelstelling niet, maar voelden gewoonlijk wel voor een zelfstandiger status van Indonesië binnen het Nederlandse Koninkrijk. Veel van deze leden waren hoge bestuursambtenaren, zoals de Soendanees Wiranatakoesoema, de Balinees Soekawati en, sinds 1931, de Javaan Soetardjo.

De ingreep van eind 1929 liet de non-coöperatieve vleugel van de nationale beweging ontredderd achter. De arrestatie van Soekarno leidde niet tot massale protesten onder de Indonesische bevolking - evenmin als de bevolking van India in 1922 in beweging gekomen was tegen de gevangenneming van Gandhi. Wel belegde de federatie PPPKI een protestbijeenkomst in Batavia, die onder meer werd toegesproken door Agoes Salim en Soetomo. De PNI schortte al haar politieke activiteiten op. Ook op het vonnis van december 1930 volgden nauwelijks openbare protesten. Doordat dit vonnis de PNI aanmerkte als een vereniging die het plegen van misdrijven beoogde, werd het deze partij onmogelijk nog politiek te functioneren. Het bestuur van de PNI besloot daarom de partij te ontbinden, nadat het vonnis in april 1931 in hoger beroep was bevestigd. Tegelijk richtte men een nieuwe partij op, de Partai Indonesia, met een doelomschrijving die niet wezenlijk van die van de PNI 
verschilde. Sartono werd voorzitter van deze nieuwe partij, die men gewoonlijk als Partindo betitelde.

De door Soekarno in 1927 bewerkstelligde samenwerking binnen de nationale beweging ging tijdens zijn gevangenschap meer en meer verloren. Soetomo zette zijn Soerabajase Studieclub in 1930 om in een eigen politieke partij, de Persatoean Bangsa Indonesia (PBI, Unie van het Indonesische Volk). De Sarekat Islam, in ledental nog steeds de grootste partij, raakte in conflict met Soetomo en trad uit de federatie PPPKI. Het beleid van het PNI-bestuur verwierf niet de instemming van alle PNI-leden; een aantal van hen sloot zich dan ook niet bij de Partindo aan. De scherpste kritiek kwam uit Nederland van Hatta. In de gang van zaken sinds eind 1929 zag hij al zijn bezwaren bevestigd tegen de door Soekarno gevolgde koers. Naar zijn mening had deze zich te veel gericht op het kweken van een revolutionaire stemming onder de massa's zonder eerst een sterke basis op te bouwen; toen het er op aankwam was die stemming dan ook weinig waard gebleken. Hatta vond het onjuist dat het PNI-bestuur de partij zelf ontbonden had. Hij was niet bereid zich bij de Partindo aan te sluiten en keurde het af dat men het woord 'nationaal' in de naam van de nieuwe partij had laten vallen.

Terwijl de Partindo in de tweede helft van 1931 snel groeide, hielden Hatta's geestverwanten in Indonesië zich bezig met de vorming van een andere organisatie, die zich zou moeten richten op stelselmatige scholing om de massa's tot nationale bewustwording op te voeden. Deze organisatie, die zich aanvankelijk als een 'club' aandiende, kreeg eind van het jaar vorm onder de naam Pendidikan Nasional Indonesia (Nationale Indonesische Scholing). Men noemde haar meestal de PNI Baroe (Nieuwe PNI).

In deze verwarde situatie organiseerde de PPPKI een congres dat van 3 tot 5 januari 1932 in Soerabaja plaatsvond onder de naam Kongres Indonesia Raja (Congres van Groot Indonesië). Men had deze data gekozen om Soekarno, die op 31 december uit gevangenschap vrijkwam, in staat te stellen er aan deel te nemen. Bij zijn vrijlating werd Soekarno afgehaald door Thamrin, samen met enige Partindo-leiders. De volgende dag reisde hij eerst naar Jogja, waar hij een bezoek bracht aan één van de pioniers van de nationale beweging, $\mathrm{Ki}$ Hadjar Dewantoro, die vroeger Soewardi Soerjaningrat heette, maar ook als leider van de Taman Siswa-scholen steeds in contact met de beweging was gebleven. Op 2 januari reisde hij door naar Soerabaja. De hele treinreis werd een triomftocht; op alle stations juichten menigten hem toe. Op het congres zei hij zich te zullen inzetten om een eind te maken aan de verdeeldheid die in de nationale beweging was ontstaan.

In de daarop volgende maanden probeerde Soekarno de Partindo en de PNI Baroe tot elkaar te brengen. Hij sprak daartoe onder meer met Sjahrir, die na zijn terugkeer uit Nederland de leiding van de PNI Baroe op zich had genomen. Na een half jaar gaf Soekarno zijn pogingen op en trad hij toe tot de 
Partindo. De partij stelde hem aan als leider van de propaganda. Kort daarna keerde Hatta uit Nederland terug en werd hij voorzitter van de PNI Baroe, die nu ging optreden als een concurrerende politieke partij. Deze partij stelde zich op socialistische grondslag en stond in dat opzicht links van de Partindo.

Intussen verschilde het politieke klimaat aanzienlijk van dat voor Soekarno's gevangenschap. In september 1931 was De Graeff opgevolgd door B.C. de Jonge. Deze kende Indonesië nauwelijks, al had hij er eens samen met F.C. Gerretson enkele weken rondgereisd. Tijdens de Eerste Wereldoorlog was hij enige tijd minister van oorlog geweest, daarna had hij leidende functies vervuld bij grote oliemaatschappijen. Anders dan De Graeff, die geprobeerd had het vertrouwen van de Indonesische nationalisten te winnen, wilde de nieuwe gouverneur-generaal juist vertrouwen vinden bij de Europese bevolkingsgroep. Voor het Indonesisch nationalisme toonde hij geen begrip. Keer op keer zei hij, dat de Nederlanders al driehonderd jaar in Indië waren en er zeker nog wel driehonderd jaar zouden blijven. Toen Thamrin in 1932 in de Volksraad verklaarde, dat de Nationale Fractie zich de zo spoedig mogelijke onafhankelijkheid van Indonesië ten doel stelde, liet De Jonge weten dat Indonesische onafhankelijkheid voor het gouvernement onbespreekbaar was en dat opwekkingen daartoe buiten de Volksraad een strafbaar feit konden opleveren. Tijdens zijn bewind werd het zowel bij de Nederlands-Indische overheid als in de Nederlands-Indische pers gebruikelijk om de term 'extremisten' te gebruiken voor alle Indonesiërs die zich voor nationale onafhankelijkheid inzetten, ook als zij, zoals Thamrin, bereid waren in vertegenwoordigende lichamen plaats te nemen.

Ook in een ander opzicht was er een groot verschil met de tijd waarin de PNI actief was geweest. In die jaren draaide de economie in de kolonie op volle toeren. Inmiddels was de wereldcrisis ingetreden, die juist Indonesië bijzonder ernstig trof, omdat het in uitzonderlijke mate van export afhankelijk was. De totale waarde van de Indonesische export daalde in enkele jaren tot een kwart. Honderdduizenden Indonesiërs en duizenden Europeanen (onder wie veel Indo-Europeanen) werden ontslagen. Lonen en salarissen gingen drastisch omlaag. Terwijl het gouvernement tijdens de hoogconjunctuur niet evenredig had kunnen meedelen in de winsten van de westerse ondernemingen, werd het nu wel getroffen door een dramatische terugval van zijn inkomsten. Daardoor gedwongen bracht het de overheidsuitgaven in vier jaar tot minder dan de helft terug. De verdere maatregelen die het gouvernement nam om de gevolgen van de crisis op te vangen strekten in de eerste plaats tot bescherming van de Europese bevolking en de westerse ondernemingen. Men ging ervan uit dat de inheemsen zich gemakkelijker konden aanpassen, omdat hun levensstandaard lager was en zij konden terugvallen op de agrarische dorpseconomie met haar productie voor eigen behoeften. De crisis leidde dan ook tot een ingrijpende verarming van de Indonesische bevolking. 
De nationalistische beweging (voorzover niet in etnisch of religieus verband georganiseerd) was in deze tijd belichaamd in drie partijen: de PBI van Soetomo, de Partindo van Sartono en Soekarno en de PNI-Baroe van Hatta en Sjahrir. De PBI had haar aanhang voornamelijk in Oost-Java en hield zich in het bijzonder bezig met de vorming van inheemse instellingen op economisch, sociaal en cultureel gebied. Zonder zich op non-coöperatie vast te leggen beklemtoonde zij het belang van Indonesische zelfwerkzaamheid. De Partindo en de PNI Baroe stonden op een strikt non-coöperatiestandpunt en richtten zich in de eerste plaats op politiek werk. Daarbij hechtte de Partindo veel belang aan bewustmaking van de bevolking, terwijl de PNI Baroe het accent op kadervorming legde. De verstandhouding tussen deze drie partijen en hun leiders was gespannen. Uit ergernis over kritiek van Soekarno trad Soetomo af als voorzitter van de federatie PPPKI (de door vrijwel alle groeperingen gewaardeerde Thamrin volgde hem op). In hun partijbladen lazen Soekarno en Hatta elkaar de les over de juiste toepassing van de noncoöperatiepolitiek.

In tegenstelling tot de Partindo plaatste de PNI Baroe de vrijheidsstrijd in het kader van de klassenstrijd en veroordeelde zij niet alleen het uitheemse maar ook het inheemse kapitalisme. Soekarno wilde tegenover Hatta's socialisme een eigen ideologie stellen. Hij kende de voornaamste rol in de vrijheidsstrijd toe aan de minst bedeelde Indonesiërs zoals boeren en arbeiders, voerde de naam Marhaen in voor de Indonesische 'kleine man' en betitelde zijn politieke filosofie als 'marhaenisme'. In zijn openbare toespraken wist hij zijn toehoorders als vanouds tot grote geestdrift te brengen. De meeste toespraken hield hij in Bandoeng, maar hij maakte ook propagandareizen door Midden- en Oost-Java.

Hoewel Soekarno voor het grote publiek het boegbeeld van de Partindo was, had hij binnen die partij niet meer zo'n overheersende positie als vroeger in de PNI. De leiding berustte nu grotendeels bij oud-leden van de Perhimpoenan Indonesia. Ook de studentenleiders Amir Sjarifoeddin en Yamin speelden een belangrijke rol. Pas een Partindo-congres van april 1933 koos Soekarno tot partijvoorzitter; Amir Sjarifoeddin werd toen vice-voorzitter. Wel had Soekarno de leiding over het partijdistrict Bandoeng stevig in handen. Hij was daar actief als spreker, als redacteur van partij-organen en als leider van een kaderschool; ook spande hij zich in om het ledental van zijn district hoog op te voeren. In totaal bereikte de Partindo in 1933 een omvang van twintigduizend leden.

Het ledental van de PNI Baroe bleef beperkt tot ongeveer duizend. In het voorjaar van 1933 vergezelde Hatta een bevriende zakenman op een reis van enige maanden door Japan. Bij zijn aankomst werd hij in de Japanse pers als de 'Gandhi van Java' aangeduid, maar zelf ging hij politieke contacten uit de weg. 
Verzet tegen de wilde-scholenordonnantie

Bij zijn pogingen om de invloed van het Indonesisch nationalisme terug te dringen richtte het gouvernement zich onder meer op de wilde scholen. Sinds 1923 beschikte het over wettelijke mogelijkheden om het onderwijs op die scholen te controleren en om docenten te verbieden daar les te geven. Het wilde nu een stap verder gaan en ontwierp een ordonnantie die bepaalde, dat ongesubsidieerde particuliere scholen en daar werkende docenten voortaan vergunningen van het bestuur nodig zouden hebben. Als één van de argumenten daarvoor voerde men aan, dat zulk een vergunningenstelsel nodig was om de kwaliteit van het onderwijs te waarborgen. Dit argument klonk weinig overtuigend, omdat het gouvernement kort daarvoor juist besloten had de officiële Hollandsch-Inlandsche Scholen niet verder uit te breiden. De Volksraad bracht in het vergunningenstelsel enige beperkingen aan en aanvaardde daarna de ordonnantie met ruime meerderheid. De ordonnantie zou op 1 oktober 1932 van kracht worden; scholen en docenten zouden daarna nog een half jaar de tijd krijgen om vergunningen aan te vragen.

Deze 'wilde-scholenordonnantie' stuitte op fel verzet bij de veelsoortige organisaties die zich met particulier onderwijs bezighielden. Ki Hadjar Dewantoro stuurde op 1 oktober een telegram aan gouverneur-generaal De Jonge, waarin hij de ordonnantie een 'misgreep' noemde en 'hardnekkig lijdelijk verzet' aankondigde. Van vele kanten kreeg hij steuntoezeggingen, onder meer van Soekarno, Soetomo en Thamrin. Het gouvernement probeerde Dewantoro tot andere gedachten te brengen met toezeggingen over de manier waarop het de ordonnantie zou uitvoeren, maar hij bleef erbij dat de ordonnantie moest worden ingetrokken.

Het verzet tegen de ordonnantie breidde zich als een vloedgolf uit. Onderwijzers-, studenten- en vrouwenorganisaties namen er aan deel naast politieke organisaties, zowel non-coöperatieve als coöperatieve. Boedi Oetomo en Pasoendan dreigden uit de Volksraad en andere vertegenwoordigende lichamen te zullen stappen als de ordonnantie niet voor 1 april 1933 ingetrokken werd. Het verzet leefde niet alleen in kringen van de nationale beweging maar ook bijzonder sterk binnen moslim-organisaties, die de ordonnantie als anti-islamitisch beschouwden. Bovendien kreeg het verzet steun van de kant van Chinezen en Arabieren. De tegenstanders van de ordonnantie vormden overal plaatselijke comités en belegden talloze protestvergaderingen.

Ki Hadjar Dewantoro groeide uit tot een nationale figuur. Naar zijn richtlijnen zou het lijdelijk verzet bestaan in de weigering van alle onder de ordonnantie vallende scholen en docenten om een vergunning aan te vragen, ook als men er zeker van kon zijn zulk een vergunning te zullen krijgen. Daarop zou het gouvernement de docenten en schoolbesturen moeten vervolgen; dezen zouden de hun opgelegde boetes niet betalen; het gouvernement zou de wan- 
betalers in hechtenis moeten nemen; de gevangenissen zouden overvol raken en vrijwilligers zouden de plaats van de gearresteerde docenten innemen.

Hoewel sommige adviseurs van de gouverneur-generaal betoogden dat het gouvernement niet voor druk moest wijken, voelde De Jonge er niet voor de zaak op de spits te drijven en daarmee 'van Dewantoro een Gandhi te maken'. Op basis van een voorstel van Wiranatakoesoema in de Volksraad werd de ordonnantie begin 1933 buiten werking gesteld. Daarna kwamen gouvernement en Volksraad een nieuwe regeling overeen, die in feite naar het stelsel van 1923 terugkeerde. De nationale beweging had in ongewone eensgezindheid een overwinning op het gouvernement behaald.

\section{Muiterij op 'De Zeven Provinciën'}

Dat Soekarno zijn opzwepende agitatie hervat had en dat de wildescholenordonnantie op massaal verzet stuitte, vergrootte de spanning onder de Europese bevolking van Indonesië. In februari 1933 sloeg de spanning bij een aanzienlijk deel van die bevolking om in paniek als gevolg van een incident waar de Indonesische nationale beweging niet rechtstreeks bij betrokken was: een muiterij van marinepersoneel die voortkwam uit protestacties tegen salariskortingen.

De economische crisis bracht het gouvernement sinds 1930 tot rigoureuze bezuinigingen, niet alleen op de civiele uitgaven zoals die voor onderwijs en volksgezondheid, maar ook op de militaire uitgaven. Zo werd de sterkte van het koloniale leger in enkele jaren verminderd van 37.000 tot 31.000 man. In 1931 gingen zowel de overheidssalarissen als de traktementen bij leger en marine tweemaal met $5 \%$ omlaag. Het lagere marinepersoneel was één van de best georganiseerde beroepsgroepen in Nederlands-Indië. Veel Europese schepelingen behoorden tot vakbonden die hun hoofdzetel in Nederland hadden en verbonden waren met de SDAP. Daarnaast bestonden er Inlandse matrozenbonden, waarvan de grootste eveneens socialistisch georiënteerd was. Eind 1932 verkeerde men bij de marine in spanning over nieuwe salariskortingen. Voor het overheidspersoneel was toen juist een verdere korting van $7 \%$ aangekondigd, maar het was onzeker of dit ook voor de marine zou gelden. Nadat honderden korporaals en manschappen in Soerabaja tegen zulk een korting gedemonstreerd hadden, wekte een officiële verklaring bij de jaarwisseling de indruk dat de marinetraktementen niet verder omlaag zouden gaan. Enige weken later bleek dat deze traktementen toch verlaagd werden, en wel met $4 \%$ voor het Europese en met $7 \%$ voor het Inlandse personeel. Dit leidde in Soerabaja niet alleen tot nieuwe demonstraties maar ook tot dienstweigering op grote schaal. Bijna vijfhonderd marinemensen, merendeels Inlanders, werden daarop gearresteerd. 
Het pantserschip 'De Zeven Provinciën' was een groot maar verouderd oorlogsschip, dat voor de opleiding van marinepersoneel gebruikt werd. Op 2 januari 1933 was het van Soerabaja vertrokken voor een oefenreis rond Sumatra, met aan boord 256 Inlandse en 141 Europese schepelingen, onder wie dertig officieren. Toen het schip zich ter hoogte van Noord-Sumatra bevond, vernam de bemanning uit telegrammen zowel van de nieuwe salariskortingen als van de dienstweigeringen en de arrestaties in Soerabaja. Kort daarna ging het schip voor anker voor Koetaradja. Op zaterdagavond 4 februari, terwijl een deel van de bemanning zich aan wal bevond, onder wie ook de commandant en verscheidene andere officieren, maakten Inlandse schepelingen zich van het schip meester en isoleerden zij de aan boord zijnde officieren op het achterschip. Een deel van het lagere Europese personeel sloot zich bij de muiters aan. Bestuurd door Inlands personeel voer 'De Zeven Provinciën' weg. De volgende ochtend maakten de muiters radiografisch bekend, dat zij het schip tijdelijk hadden overgenomen, dat ze opstoomden naar Soerabaja, dat ze geen geweld beoogden en dat hun actie bedoeld was als protest tegen de salariskortingen en tegen de arrestatie van marinemensen in Soerabaja.

Het nieuws van de muiterij schokte veel Nederlanders in de kolonie buitengewoon. Hun veiligheid was in het geding als men de gewapende macht niet meer vertrouwen kon. Bovendien werd hun nationale gevoel gekwetst, omdat de marine bij uitstek een symbool van Nederlands grootheid was. Verder waren velen pijnlijk verrast omdat Inlanders blijk gaven een groot schip te kunnen besturen. Hoewel de muiterij werd aangediend als een actie in het kader van een loonconflict, vatten de meeste Nederlanders haar op als een politiek gemotiveerde aanslag op het koloniale gezag. Men wist trouwens de eerste dagen nog niet, dat ook Europees marinepersoneel aan de actie deelnam. Omdat men de muiterij als een politieke opstand opvatte, vreesde men voor verdere opstandige acties in de kolonie.

Op 7 februari vond in Batavia voor het paleis van de gouverneur-generaal een grote betoging plaats waarin duizenden (voornamelijk Nederlanders en Indische Nederlanders) getuigden van hun trouw aan het gezag en van hun liefde voor vorstin en vaderland. Muziekkorpsen speelden het 'Wien Nêerlands bloed' en het 'Wilhelmus'. De betogers keerden zich niet alleen tegen het Indonesisch nationalisme, maar ook tegen socialisme en communisme.

Intussen naderde 'De Zeven Provinciën' langs de westkust van Sumatra. Enige personeelsbonden boden aan tussen de muiters en de marineleiding te bemiddelen. De gouverneur-generaal en de commandant van de zeemacht sloegen dit af; zij wensten onvoorwaardelijke capitulatie. Om de discipline binnen de marine te herstellen waren zij bereid het pantserschip zelf op te offeren en het leven van de opvarenden op het spel te zetten, met inbegrip van de door de muiters vastgehouden officieren. Omdat het schip beschikte over zwaarder scheepsgeschut dan de andere marineschepen maar niet over 
luchtafweergeschut, bereidde men zich er op voor het eerst met vliegtuigbommen en dan met torpedo's aan te vallen. Op 10 februari verscheen 'De Zeven Provinciën' bij Straat Soenda. Op een sommatie om zich over te geven reageerde de leiding van de muiterij negatief. Volgens de instructies moest een vliegtuig daarop voor het schip een 'waarschuwingsbom' neerwerpen, maar de bom trof 'De Zeven Provinciën' zelf en doodde drieëntwintig opvarenden, onder wie de voornaamste actieleider. Onmiddellijk hierna gaven de muiters zich over.

Het bericht van hun capitulatie wekte uitbundige vreugde onder de Nederlanders in de kolonie. De manier waarop aan de muiterij een eind gemaakt was oogstte bewondering. Tegelijk verbreidde zich het gevoel dat een keerpunt bereikt was en dat het tijd was voor een radicale afrekening met alle politieke agitatie die het koloniale gezag ondermijnde.

Het strafrechterlijk onderzoek van de muiterij bracht geen nationalistisch of communistisch complot aan het licht. Bijna de helft van de bemanningsleden werd veroordeeld tot gevangenisstraffen, die uiteenliepen van enkele maanden tot achttien jaar. In 1937 stelde de regering allen die nog gevangen zaten in vrijheid ter gelegenheid van het huwelijk van prinses Juliana.

De affaire van 'De Zeven Provinciën' leidde ook in Nederland tot emotionele reacties. Een meerderheid stond achter het harde optreden van het gouvernement; een minderheid toonde zich ontsteld over de bom. Rechtse politici zagen de dienstweigeringen en de muiterij als symptomen van een gezagscrisis en riepen op tot strenge matregelen. Colijn, de leider van de $\mathrm{ARP}$, had trouwens al meteen gezegd dat men het schip desnoods met een torpedo tot zinken moest brengen. Sommige socialistische politici en persorganen toonden sympathie voor de muiters. Officieel veroordeelde de SDAP de muiterij, maar keurde zij de gewelddadige beëindiging af. Communisten en andere links-radicalen vatten de muiterij op als gericht tegen het koloniale bestel en verheerlijkten de muiters als revolutionaire helden. Sneevliet (die intussen met Moskou gebroken had) riep het Nederlandse marinepersoneel op het voorbeeld van hun kameraden in Indonesië te volgen; hij kreeg daarvoor vijf maanden gevangenisstraf. De regering verbood alle militairen lid te zijn van of steun te verlenen aan de SDAP of andere sociaal-democratische organisaties en verklaarde alle socialistische dagbladen en andere publicaties tot voor de militairen verboden geschriften. In dit klimaat van verscherpte politieke tegenstellingen vonden in april 1933 verkiezingen voor de Tweede Kamer plaats. De SDAP leed verlies, maar zowel de communistische partij als de ARP boekte winst. Als lid van de communistische fractie kreeg voor het eerst een Indonesiër zitting in het parlement, namelijk Roestam Effendi, oudvoorzitter van de Perhimpoenan Indonesia. Na de verkiezingen kwam een nieuwe regering tot stand onder Colijn, de man van de gezagshandhaving. Hij ging ook het ministerie van koloniën beheren. 
Als minister van koloniën hoefde Colijn het gouvernement niet aan te sporen om het gezag met harde hand te handhaven, want daar ging het uit zichzelf al toe over. Zijn bemoeienis met het beleid in Nederlands-Indië strekte er voornamelijk toe de overheidsuitgaven zo ver mogelijk te verlagen. Daarbij verlangde hij nog rigoureuzere bezuinigingen dan waar gouverneur-generaal De Jonge toe bereid was. Colijn gaf geen uitvoering aan zijn vroegere denkbeelden om de staatsinrichting van de kolonie in federale zin te hervormen (zulk een hervorming zou trouwens hoge uitgaven hebben meegebracht). Wel zorgde hij voor een naamsverandering van het koloniale leger, waarin hij zijn loopbaan begonnen was. In aanmerking nemende dat de marine vanouds Koninklijke Marine heette en dat men het Nederlandse leger al enige tijd Koninklijke Landmacht was gaan noemen, verzocht hij het gouvernement het leger in Nederlands-Indië voortaan als Koninklijk Nederlands-Indisch Leger aan te duiden. In de afgekorte vorm KNIL raakte deze nieuwe naam van het koloniale leger al snel ingeburgerd. Overigens was dit leger sinds de Wereldoorlog van karakter veranderd; het was hervormd tot een politieleger. $\mathrm{Nu}$ het bezuinigingsbeleid leidde tot een aanzienlijke inkrimping van de legersterkte, maakte de legerleiding daarvan gebruik om alle militairen die zij niet volledig vertrouwde te ontslaan.

\section{Onderdrukking van de Indonesische vrijheidsbeweging}

Al in juni 1932 had gouverneur-generaal De Jonge in de Volksraad gewaarschuwd dat het gouvernement van plan was 'elke verstoring van rust en orde met kracht tegen te gaan'. Sindsdien was de politie harder gaan optreden tegen uitlatingen die zij opruiend achtte. In september keerde De Jonge zich scherp tegen politieke activiteiten van personen in gouvernementsdienst. Daartoe zond hij een nieuwe 'muilkorfcirculaire' uit, waarbij een loyaliteitsverklaring was gevoegd die ambtenaren desgevraagd zouden moeten ondertekenen. De verklaring hield in, dat de betrokkene zich zou onthouden van elke daad, met inbegrip van propaganda of bevordering van propaganda, die ondermijning van het overheidsgezag of ontwrichting van de openbare orde ten doel had of die daartoe leidde, en dat hij wist het gevaar te lopen te worden ontslagen als hij deze belofte niet zou nakomen.

De muiterij op 'De Zeven Provinciën' overtuigde het gouvernement ervan dat bijzondere maatregelen nodig waren tot herstel en handhaving van het gezag. Een van zijn eerste daden was een opdracht aan alle gouverneurs en residenten om strenger op te treden tegen politieke vergaderingen waarin actie tegen overheidsmaatregelen gevoerd werd. Toen Soekarno en andere leiders van de Partindo in februari en maart 1933 een propagandatournee door Midden-Java maakten, ontbond de politie de meeste bijeenkomsten voortijdig, 
terwijl sommige bijeenkomsten al van te voren verboden werden. Ook de PNI Baroe en de Sarekat Islam waren het doelwit van repressieve maatregelen. In april interpelleerde Thamrin het gouvernement in de Volksraad over het verscherpte politie-optreden. Hij legde daarbij een lange lijst over van arrestaties en huiszoekingen, van het verbieden of uiteenjagen van vergaderingen en van inbeslagneming of verbod van persorganen. Bij de beantwoording van deze interpellatie noemde het gouvernement de Partindo, de PNI Baroe en de Sarekat Islam 'onmiskenbaar extremistisch' en verklaarde het dat de genomen maatregelen noodzakelijk waren geweest om opruiing tegen te gaan.

De Partindo hanteerde na haar partijcongres van april 1933 dikwijls de leuze 'Repoeblik Indonesia'. Dit bleek bijzondere aanstoot te geven aan veel Nederlanders bij wie verabsolutering van de Rijkseenheid hand in hand ging met verheerlijking van het koningshuis. Het gouvernement gaf opdracht vergaderingen onmiddellijk zonder voorafgaande waarschuwing te sluiten wanneer deze term gebruikt werd.

In juni werd het aan alle overheidsdienaren verboden lid te zijn van de Partindo of de PNI Baroe. Intussen bleken de veelvuldige ingrepen van het bestuur bij toespraken van Soekarno zijn populariteit eerder te vergroten dan te schaden. Het gouvernement besloot nu hem uit de Nederlands-Indische samenleving te verwijderen. Op 1 augustus 1933 werd hij in Batavia gearresteerd na een vergadering ten huize van Thamrin.

Soekarno, die weer naar de gevangenis in Soekamiskin werd overgebracht, wist dat hem geen nieuw proces wachtte, maar dat men hem op grond van de exorbitante rechten wilde interneren. In het vooruitzicht de rest van zijn leven in Boven-Digoel te moeten doorbrengen kreeg hij een volledige morele inzinking. Hij schreef brieven aan het gouvernement waarin hij spijt betuigde van zijn daden en beloofde zich geheel uit de politiek terug te trekken als hij zou worden vrijgelaten; bovendien machtigde hij het gouvernement dit bekend te maken. Hij onderstreepte zijn 'bekering' door uit de Partindo te treden. Soekarno's ommezwaai verbijsterde de nationale beweging. Hatta verklaarde dat de politicus Soekarno had afgedaan, maar dat men zijn vroegere verdiensten voor de beweging nooit zou vergeten. Het gouvernement ging echter niet op Soekarno's aanbod in en besloot in december hem wel degelijk te verbannen, weliswaar niet naar Boven-Digoel maar naar het eiland Flores. Die verbanning hielp veel van zijn bewonderaars om zijn knieval voor het koloniale bestuur te vergeven en te vergeten; bovendien nam Tjipto Mangoenkoesoemo het voor hem op. Sommige andere politici konden deze episode minder gemakkelijk vergeten.

In 1933 werd ook de vice-voorzitter van de Partindo, Amir Sjarifoeddin, gearresteerd. Anders dan Soekarno werd hij wel berecht; hij kreeg anderhalf jaar gevangenisstraf.

De leiders van de PNI Baroe meenden dat de maatregelen van het gou- 
SOEWARSIH DJOJOPOESPITO

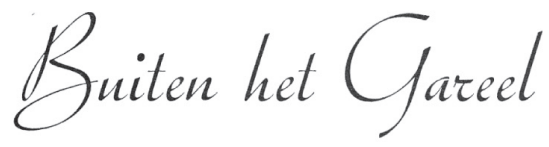

INDONESISCHE ROMAN

MET EEN INLEIDING VAN

E. DU PERRON

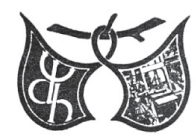

UITGEVERSMAATSCHAPPIJ W. DE HAAN N.V.

UTRECHT

Deze door de Soendanese onderwijzeres Soewarsih Djojopoespito (1912-1977) in het Nederlands geschreven roman over het leven van een nationalistisch echtpaar tijdens de onderdrukking van de Indonesische vrijheidsbeweging werd in Nederland gepubliceerd in november 1940, toen het land al door Duitsland bezet was. 
vernement aantoonden hoe onverantwoordelijk de Partindo had gehandeld door opnieuw de weg van grootscheepse agitatie op te gaan. Zij dachten zelf met hun concentratie op kadervorming minder risico te lopen. Dit was een misvatting. Het gouvernement vond de socialistische PNI Baroe in wezen gevaarlijker dan de burgerlijke Partindo. De PID beschouwde Hatta en Sjahrir als crypto-communisten wegens hun contacten in Europa met leden van de communistische beweging. In oktober 1933 kreeg zowel de PNI Baroe als de Partindo een volledig vergaderverbod, ook voor besloten vergaderingen. Op 24 februari 1934 voerde de politie een razzia tegen de PNI Baroe uit, met tientallen huiszoekingen en tal van arrestaties. Verscheidene voormannen van de partij werden na verhoor weer vrijgelaten, maar zeven, onder wie Hatta en Sjahrir, bleven in hechtenis. Zij werden wél naar Boven-Digoel verbannen. Sjahrir was ten tijde van zijn arrestatie 24 jaar oud en stond toen op het punt naar Nederland terug te keren om zijn rechtenstudie voort te zetten.

Het gouvernement duldde geen acties voor nationale onafhankelijkheid meer. Het richtte zich daarbij niet alleen op de politieke partijen, maar ook op de jeugdbeweging, de studentenbeweging en de scholen. Weliswaar had het moeten afzien van een vergunningenstelsel voor de wilde scholen, maar ook de bestaande regeling bood ruime mogelijkheden om nationalistische propaganda op zulke scholen tegen te gaan. Zo kregen tal van nationalistische docenten een onderwijsverbod.

Hoewel de bestaande wetgeving de koloniale overheid vele instrumenten verschafte om politieke activiteiten te onderdrukken, vond het gouvernement het nodig dit wettelijk instrumentarium verder uit te breiden. Zo kwam er in 1934 naast de regeling voor het ongesubsidieerde particuliere onderwijs ook een ordonnantie voor het gesubsidieerde particuliere onderwijs. Daarin werd de gouverneur-generaal gemachtigd om aan een docent een onderwijsverbod op te leggen als hij in of buiten de school blijk gaf van een mentaliteit 'strijdig met de verschuldigde gehoorzaamheid aan de wetten des lands'. Tevens zou het gouvernement voortaan de subsidiëring kunnen beëindigen van particuliere scholen waarvan hoofden of bestuurders blijk gaven van een mentaliteit 'onverenigbaar met de gehoorzaamheid en de eerbied aan het overheidsgezag verschuldigd'. Om nationalistische agitatie op de hogescholen tegen te gaan werd bovendien een ordonnantie voor het hoger onderwijs ingevoerd, die de gouverneur-generaal machtigde om aan studenten voor een tijdvak van vijf jaar de toegang tot de hogescholen te verbieden.

De meest repressieve wetgeving kwam begin 1935 tot stand. Een nieuwe ordonnantie machtigde de gouverneur-generaal om 'ter verzekering van de openbare orde en rust' censuur in te stellen op het post-, telegraaf- en telefoonverkeer. Hierbij kregen de censuurambtenaren niet alleen het recht om van de inhoud van brieven, telegrammen en telefoongesprekken kennis te nemen, maar ook om, ter voorkoming van 'gevaar voor de openbare orde en rust', 
brieven aan te houden of te vernietigen, telegrammen niet te verzenden en telefoongesprekken te beletten of af te breken. Een andere ordonnantie voerde verdere beperkingen op de vrijheid van vereniging en vergadering in. Terwijl tot dan toe alleen het Hooggerechtshof een vereniging kon verbieden, werd nu de gouverneur-generaal zelf bevoegd om 'in het belang van de openbare orde' verenigingen te verbieden. Verder kreeg de politie voortaan ook vrije toegang tot besloten vergaderingen van politieke aard.

De gouverneur-generaal had voor de uitoefening van al de hierboven genoemde bevoegdheden geen instemming van de Raad van Indië nodig. Ook werd er niet voorzien in enigerlei toetsing door de rechterlijke macht. In de Volksraad werden al deze ordonnanties met ruime meerderheid aanvaard. Tegenstemmen kwamen vrijwel alleen van de Nationale Fractie. De Vaderlandsche Club had overigens nog een stap verder willen gaan. Zij stelde in 1934 voor om Thamrin en andere 'extreem-nationalisten' uit de Volksraad te weren.

Voor de onderdrukking van de Indonesische onafhankelijkheidsbeweging beschikte het gouvernement niet alleen over uitzonderlijke wettelijke bevoegdheden, maar ook over een gespecialiseerde organisatie in de vorm van de Politieke Inlichtingen Dienst (PID, zie pp. 167-8). Terwijl de gewone politie en het KNIL in de crisisjaren door bezuinigingen getroffen werden, breidden de activiteiten van de PID zich sterk uit. De agenten van de PID leken alomtegenwoordig. Zij schaduwden nationalistische politici, verhoorden en vermaanden politieke activisten, controleerden en ontbonden vergaderingen, deden invallen in redactiebureaus en schoollokalen, onderschepten correspondentie en infiltreerden met spionnen in besturen en actiegroepen. De leiding van de PID zorgde voor de politieke voorlichting van het gouvernement.

Voor het gouvernement was het Indonesische onafhankelijkheidsstreven geen politiek probleem meer, maar nog alleen een 'politioneel' probleem. Voor de inheemse bevolking was de kolonie een politiestaat geworden.

\section{Einde van de non-coöperatiepolitiek}

In december 1934 overleed Tjokroaminoto, 52 jaar oud. Hoewel zijn ster als volksleider verbleekt was en hij politiek op een zijspoor geraakt was, werd hij nu van vele kanten gehuldigd als pionier van de nationale beweging. Zijn dood leek het einde te markeren van een ruim twintigjarig tijdvak van onstuimige activiteit voor de politieke emancipatie van de Indonesische bevolking.

De sinds 1933 door het gouvernement genomen maatregelen maakten het aan non-coöperatieve partijen als de Partindo en de PNI Baroe moeilijk nog zinvol te functioneren. Door het hun opgelegde vergaderverbod en door talrijke verschijningsverboden voor hun partij-organen konden zij hun publiek 
nauwelijks meer bereiken. Wanneer zij toch nog politiek werk probeerden te doen, werd dit door de PID vaak als ondergrondse actie opgevat, wat dan tot verdere repressie leidde.

De uitschakeling van deze partijen vergrootte het belang van de Volksraad als platform voor de nationale beweging, want hier kon men zich nog openlijk voor een onafhankelijk Indonesië uitspreken zonder strafrechtelijke vervolging te riskeren. Thamrin, voorzitter van de Nationale Fractie, werd nu de meest gezaghebbende voorman van de nationale beweging. Hij was in 1931 opnieuw tot lid van de Volksraad benoemd en maakte sindsdien ook deel uit van het College van Gedelegeerden. In 1935 en 1939 keerde hij als gekozen lid in de Volksraad terug en in 1939 werd hij vice-voorzitter. Thamrin was een strijdvaardige debater en een harde werker, die beginselvastheid met pragmatisme combineerde en de kunst verstond ook met politieke tegenstanders een goede persoonlijke verstandhouding te bewaren.

De belangrijkste Indonesische fractie naast de Nationale Fractie was die van de Perhimpoenan Pegawai Bestuur Boemipoetra (PPBB, Vereniging van Inheemse Bestuursambtenaren), een in 1929 door Wiranatakoesoema opgerichte organisatie van bestuursambtenaren van alle rangen. De opvattingen van de PPBB en van de nationalisten liepen dikwijls uiteen, maar niet altijd. Zo stelde de PPBB-fractie in 1932 voor, in alle officiële stukken de term 'Inlander' door 'Indonesiër' te vervangen. Verder telde de Volksraad drie christelijke Indonesiërs wier politieke opvattingen dikwijls dicht bij die van de nationalisten lagen: de Batak T.S.G. Moelia, de Menadonees G.S.S.J. Ratoelangie (leider van de Minahasa-bond) en de Javaan Ignacius Kasimo (leider van de Indonesische katholieke partij).

Binnen de coöperatieve vleugel van de nationalistische beweging vond in 1935 een bundeling van krachten plaats. Boedi Oetomo, dat al enkele jaren eerder van karakter was veranderd door zijn lidmaatschap open te stellen zVoorzitter was Soetomo, die niet alleen de PBI had opgericht maar bovendien in 1908 tot de oprichters van Boedi Oetomo had behoord. Ook Thamrin trad tot de nieuwe partij toe. De statutaire doelomschrijving van de Parindra sprak niet over onafhankelijkheid maar over een 'luisterrijk en volmaakt Indonesië', te bereiken door versterking van de nationale geest, volledige politieke rechten en een op nationalisme en democratie gebaseerd regeersysteem. De activiteiten van de partij lagen grotendeels op sociaal en economisch terrein.

Intussen was de leiding van de Partindo gaan twijfelen aan het nut van voortzetting van de non-coöperatiepolitiek. Nu de verscherpte repressie geen ruimte meer liet voor de vroegere actiemethodieken, zou deelname aan officiele verkiezingen juist een belangrijk actiemiddel kunnen worden. Bovendien had het gouvernement vrijheid van vergadering toegezegd aan partijen die zitting in de Volksraad namen. Vanuit Nederland ging nu ook de Perhimpoenan Indonesia pleiten voor beëindiging van de non-coöperatie. De Partindo kreeg 
echter geen kans meer zulk een koerswijziging door te voeren. Zij mocht geen partijcongres houden en werd getroffen door nieuwe huiszoekingen en arrestaties. Wegens deze uitzichtloze situatie hief de Partindo zichzelf in 1936 op.

De PNI Baroe bleef formeel bestaan, maar kon vrijwel niets meer uitrichten. Tweemaal werd de hele leiding van de partij gearresteerd en naar BovenDigoel verbannen. Telkens namen anderen de opengevallen plaatsen weer in.

Voor de meeste aanhangers van de Partindo die de non-coöperatie wilden opgeven, was de Parindra te rechts. Zij gingen daarom in 1937 over tot de vorming van een nieuwe organisatie, de Gerakan Rakjat Indonesia (Indonesische Volksbeweging), ook wel Gerindo genoemd. Eén van de initiatiefnemers, de jonge medicus Adnan K. Gani, werd de eerste voorzitter; zijn opvolger was Amir Sjarifoeddin. Ook Yamin en Sartono kwamen in de leiding. De Gerindo erkende de waarde van de non-coöperatiepolitiek in het verleden, maar vond dat daar tactisch nu geen plaats meer voor was. $\mathrm{Zij}$ verklaarde te streven naar een samenleving waarin het Indonesische volk politiek, sociaal en economisch over eigen lot zou kunnen beschikken. Volgens Yamin zou Indonesië in eerste aanleg genoegen kunnen nemen met een status als die van de dominions binnen het Britse Gemenebest.

De leiding van de Gerindo had ook internationaal-politieke redenen om samenwerking met Nederland onder de huidige omstandigheden niet meer af te wijzen. Terwijl sommige voormannen van de Parindra veel bewondering voor Japan koesterden, was de Gerindo uitgesproken anti-fascistisch en antiJapans.

De pro-Japanse gevoelens van figuren als Soetomo hingen samen met de Nederlandse houding tegenover de Indonesische bevolking. Volgens de meeste Nederlanders zou die bevolking nog heel lang niet voldoende capabel zijn om een moderne samenleving te laten functioneren. Velen van hen geloofden trouwens dat alleen blanken hiertoe in staat waren en dat Indonesiërs dit nooit zouden kunnen omdat zij tot een inferieur ras behoorden. Japan vormde een levende weerlegging van deze Nederlandse pretenties. In een halve eeuw hadden de Japanners op eigen kracht een modernisering van hun land tot stand gebracht die alles ver achter zich liet wat de Nederlanders op dit punt in Indonesië gepresteerd hadden. Bovendien had Japan, terwijl het zich de verworvenheden van de westerse beschaving eigen maakte, niettemin zijn eigen cultuur bewaard en zijn eigen tradities gehandhaafd. Deze aspecten van het Japanse fenomeen maakten het tot een hoopgevend voorbeeld voor veel Indonesische nationalisten. Binnen de Gerindo was men echter meer onder de indruk van een ander aspect. Na 1930 had één van de Japanse tradities, de militaristische, de overhand gekregen. De leiders van de strijdkrachten hadden zich meester gemaakt van de staatsmacht en waren een politiek van agressie begonnen. In 1931 onderwierpen zij Mandsjoerije; in de volgende jaren bezette Japan een deel van Sjanghai en trok het Noord-China binnen en 
in 1937 begon het een algehele oorlog tegen China, waarbij het binnen een jaar de meeste grote steden veroverde. Voor de Gerindo was het duidelijk dat het Japanse militarisme ook Indonesië bedreigde, vooral omdat dit over grondstoffen beschikte waar Japan grote behoefte aan had. Onmiddellijke volledige onafhankelijkheid van Indonesië zou in de huidige situatie betekenen dat het weerloos aan Japan overgeleverd zou zijn. Buiten de Gerindo deelden slechts weinig nationalistische politici dit inzicht.

In tegenstelling tot de vroegere aanhang van de Partindo, die zich nu in de Gerindo verenigd had, bleef de Sarekat Islam aan de non-coöperatiepolitiek vasthouden. Aan de SI was geen algemeen vergaderverbod opgelegd, maar wel een verbod van politieke vergaderingen. Daarom richtte zij zich nu voornamelijk op sociale en economische kwesties. De partij kampte echter voortdurend met innerlijke verdeeldheid. Al in 1933 was Soekiman geroyeerd na een conflict met Salim en Tjokroaminoto. In 1935 en 1936 streed men in de partij over de vraag of men de non-coöperatiepolitiek moest prijsgeven. De voorzitter Agoes Salim was hiervoor geporteerd, maar stond daarmee onder meer tegenover zijn medebestuursleden Kartosoewirjo en Abikoesno Tjokrosoejoso (een jongere broer van Tjokroaminoto). Salim trad af toen de meerderheid hem niet steunde, maar bleef ijveren voor zijn visie, samen met onder meer Mohammad Roem. In 1937 werden Salim en zijn medestanders uit de Sarekat Islam gezet. Zij stichtten toen een nieuwe islamitische partij, die tot coöperatie bereid was. Ruim een jaar later richtte ook Soekiman een eigen islamitische partij op, die eveneens coöperatief gezind was en nauw verbonden was met de Moehammadiah. Binnen de Sarekat Islam zelf ontstond in 1939 opnieuw onenigheid, omdat Kartosoewirjo aan de non-coöperatiegedachte een radicaal-islamitische uitwerking wilde geven. Onder meer verzette hij zich tegen samenwerking van de SI met coöperatief gezinde partijen en pleitte hij voor de vorming van een uitsluitend op de islam gebaseerde Indonesische staat. Dit leidde wederom tot een scheuring, waarbij nu Kartosoewirjo en zijn aanhangers uit de partij werden gestoten. Zij vormden daarop een concurrerende Sarekat Islam.

De vele strubbelingen binnen de politieke islamitische beweging verhinderden overigens niet, dat niet-politieke islamitische organisaties in deze zelfde periode zeer actief waren en dat zowel de Moehammadiah als de Nahdatoel Oelama gestadig groeide. In 1937 voerden de islamitische organisaties een massale protestactie tegen een plan van het gouvernement om nieuwe regels in te voeren voor het sluiten en ontbinden van huwelijken van niet-Europeanen. Dit plan, dat beoogde de rechtspositie van islamitische gehuwde vrouwen te verbeteren, moest wegens het islamitisch verzet worden opgegeven. De triomferende organisaties stichtten daarop een federatief verband met de Arabische naam Madjlisoel Islamil A'laa Indonesia (MIAI, Hoge Islamitische Raad van Indonesië). De daarbij aangesloten bonden vertegenwoordigden tezamen honderdduizenden leden. 
India, Birma en de Filippijnen op weg naar dekolonisatie

De ontwikkeling van Nederlands-Indië naar meer zelfstandigheid was na 1929 - toen het Nederlandse parlement de 'Inlandse meerderheid' in de Volksraad aanvaardde - volledig stil komen te staan. Sommige koloniën van andere landen maakten in deze tijd wel duidelijke voortgang in de richting van dekolonisatie.

De Britse regering verklaarde in 1929 dat de natuurlijke uitkomst van de staatkundige ontwikkeling van India de status van dominion zou zijn en dat zij van plan was een Ronde Tafel Conferentie bijeen te roepen voor overleg over de eerste stappen daarheen. De Britse dominions (zoals Australië en Canada) genoten zowel intern zelfbestuur als autonomie in externe zaken, onder handhaving van een gezamenlijke band met de Britse kroon, maar met het recht om die band te verbreken. Aan de Conferentie konden leiders van de Indiase partijen en van de zelfbesturende vorstendommen deelnemen op voet van gelijkheid met vertegenwoordigers van de Britse regering en van de Britse partijen. De Ronde Tafel Conferentie hield drie zittingen, in 1930, 1931 en 1932. De eerste zitting werd geboycot door het Indian National Congress. Dit was in 1930 een grote campagne van 'burgerlijke ongehoorzaamheid' begonnen, ingeleid met een mars van Gandhi naar de kust om daar zelf zout te winnen in strijd met het zoutmonopolie van de koloniale overheid. De campagne, die minder geweldloos verliep dan beoogd was, leidde tot een honderdduizend arrestaties. Ook Gandhi belandde weer in de gevangenis. De Britse onderkoning liet hem echter begin 1931 vrij en voerde een reeks gesprekken met hem, die tot enig wederzijds vertrouwen leidden. Gandhi nam daarop in het najaar van 1931 zelf in Londen deel aan de tweede zitting van de Ronde Tafel Conferentie als vertegenwoordiger van het Congress.

De Conferentie bereikte overeenstemming over belangrijke uitgangspunten, maar leverde uiteindelijk geen definitief akkoord op. De voornaamste struikelblokken betroffen niet de verhouding met het Britse Rijk maar interne Indiase problemen, zoals de vrees van de moslims voor overheersing door de hindoes en de onwil van met zelfbestuur beklede vorsten om hun autocratische positie op te geven. Op basis van het overleg in de Ronde Tafel Conferentie nam het Britse parlement in 1935 een nieuwe Government of India Act aan, die het bestuur over de Indiase provincies vrijwel geheel in Indiase handen bracht, de bevoegdheden van de centrale wetgevende raad uitbreidde en de weg opende naar een Indiase federatie met dominion-status. In 1937 vonden verkiezingen plaats waarbij het Indian National Congress de meerderheid veroverde in een groot aantal provincies.

Eveneens in 1937 voerde Groot-Brittannië een scheiding door tussen India en Birma, waarbij Birma een eigen Huis van Afgevaardigden kreeg dat geheel uit gekozen leden bestond. Het land werd voortaan bestuurd door een uit 
Birmanen bestaande regering onder een Birmaanse minister-president. De Britse gouverneur behield slechts bepaalde bevoegdheden op het gebied van de externe verdediging en de binnenlandse veiligheid.

Intussen berustte de wetgevende macht in de Filippijnen al sinds 1916 bij een gekozen volksvertegenwoordiging, die beheerst werd door een naar onafhankelijkheid strevende nationalistische partij. De voornaamste leider van die partij, Manuel Luis Quezon, was in het begin van de eeuw nog officier geweest in het tegen Amerika vechtende opstandelingenleger. In de Verenigde Staten zelf stond onafhankelijkheid voor de Filippijnen op het programma van de Democratische Partij. De Amerikaanse voorstanders van Filippijnse onafhankelijkheid werden overigens niet alleen door idealistische motieven gedreven maar ook door Amerikaanse belangen, zoals de mogelijkheid om Filippijnse importen en Filippijnse immigratie te beperken en het vermijden van een oorlog met Japan over het bezit van de Filippijnen. De meeste Amerikaanse militaire deskundigen meenden, dat men de Filippijnen niet tegen een Japanse aanval zou kunnen verdedigen.

Begin 1933 nam het Amerikaanse congres een wet aan die voorzag in de opstelling van een grondwet door het Filippijnse volk zelf, vervolgens de instelling van een vrijwel autonoom Filippijns Gemenebest onder een gekozen president, en tenslotte na tien jaar de verlening van volledige onafhankelijkheid. Quezon had bezwaren tegen sommige onderdelen van de wet en wist de inwerkingstelling ervan tegen te houden. Een enigszins gewijzigde versie werd in 1934 definitief van kracht. Op 15 november 1935 kwam het Filippijnse Gemenebest officieel tot stand. Quezon werd president en betrok het paleis waarin vroeger de Spaanse en Amerikaanse gouverneurs gezeteld hadden. In plaats van een gouverneur had Amerika nu in Manila een Hoge Commissaris. Verder was er een bevelhebber van de Amerikaanse troepen, generaal Douglas MacArthur. Hij achtte de Filippijnen wél verdedigbaar en belastte zich op verzoek van Quezon met de opbouw van het nieuwe Filippijnse leger.

Indonesische nationalisten volgden de staatkundige ontwikkelingen met betrekking tot andere Aziatische koloniën uiteraard oplettend. Hun meeste belangstelling ging naar India uit, maar zij gaven ook aandacht aan de Filippijnen. Naar aanleiding van de eerste Amerikaanse wet stuurde de Partindo in 1933 een felicitatietelegram naar Quezon en belegde zij een druk bezochte vergadering in Batavia, waar Yamin en Amir Sjarifoeddin het woord voerden. In 1935 kreeg de uitroeping van het Filippijnse Gemenebest grote publiciteit in de Indonesische pers. Op initiatief van Thamrin (die persoonlijk met Quezon bevriend was) vond in Batavia opnieuw een speciale bijeenkomst plaats, waar onder meer Boedi Oetomo en Pasoendan aan deelnamen en waarbij wederom een gelukwens aan Quezon werd gezonden.

De Nederlanders, zowel die in Indonesië als die in Nederland, schonken in overgrote meerderheid geen enkele aandacht aan de staatkundige ontwik- 
keling van India en de Filippijnen. Voorzover zij dit wel deden, vonden zij het Britse en Amerikaanse beleid meestal onverstandig en onverantwoord. Bij voorkeur publiceerden zij in Indonesië geen informatie over de ontwikkeling van de Filippijnen. In de Volksraad noemde de woordvoerder van het gouvernement medio 1935 de aan de Filippijnen toegezegde onafhankelijkheid een 'onrijpe vrucht' waarvan de Filippijnse bevolking 'gaarne verlost' zou worden. Bij de proclamatie van het Filippijnse Gemenebest later in dat jaar kreeg de regering in Manila gelukwensen van de Britse, de Duitse, de Franse, de Japanse en de Spaanse regering, maar niet van de Nederlandse. Later verzette de Nederlandse regering zich herhaaldelijk tegen plannen van president Quezon om een bezoek aan Indonesië te brengen.

\section{De petitie-Soetardjo}

De voortgang van India, Birma en de Filippijnen op de weg naar dekolonisatie trok onder de Indonesiërs niet alleen de aandacht van westers opgeleide intellectuelen, maar ook van sommige leden van de traditionele aristocratie. Eén van hen was het Javaanse Volksraadslid Soetardjo Kartohadikoesoemo. Hij behoorde niet tot een politieke partij, maar was voorzitter van de ambtenarenbond PPBB. Zijn politieke denkbeelden verschilden aanzienlijk van die van de radicale nationalisten. Hij was conservatief gezind en beschouwde de leden van de inheemse adel als de natuurlijke leiders van de Indonesische bevolking. Naar zijn mening werd hun gezag echter voortdurend ondermijnd omdat het gouvernement hen niet als een brug naar die bevolking gebruikte maar als een buffer ertegen. Soetardjo was geporteerd voor afschaffing van het dubbele stelsel van het BB, opdat Indonesiërs ook bestuursfuncties zouden kunnen vervullen die nu voor Nederlanders gereserveerd waren. Hij was gegriefd door de vernederingen die inheemse bestuursambtenaren vaak van Nederlandse kant ondervonden en wilde de term 'Inlander' zien verdwijnen. Hij betreurde het dat Indonesiërs telkens weer gepasseerd werden voor de vervulling van verantwoordelijke posten. Een voorbeeld hiervan was het besluit van de regering in 1933 om niet twee Indonesiërs maar slechts één tot lid van de Raad van Indië te benoemen. Een ander voorbeeld was de benoeming van de voorzitter van de Volksraad in 1935. De Volksraad had hiervoor zelf drie kandidaten aanbevolen, namelijk Koesoemo Oetojo, Wiranatakoesoema en Jonkman (in die volgorde). De Nederlandse regering vond dat de Raad hiermee zijn bevoegdheden overschreden had en benoemde de Indische Nederlander W.H. van Helsdingen, die vroeger secretaris van de Raad was geweest.

Op 15 juli 1936 diende Soetardjo een voorstel in dat inhield dat de Volksraad een petitie zou richten tot de regering van het Koninkrijk en het Nederlandse parlement. Daarin zou worden gevraagd om bijeenroeping van een conferentie 
van vertegenwoordigers van Nederland en Nederlands-Indië om op voet van gelijkheid een plan op te stellen teneinde aan Nederlands-Indië binnen tien jaar langs de weg van geleidelijke hervorming de staat van zelfstandigheid toe te kennen binnen de grenzen van artikel 1 van de Grondwet. Het denkbeeld van een conferentie op voet van gelijkheid was kennelijk geïnspireerd door de Londense Ronde Tafel Conferentie over India, de termijn van tien jaar door het voorbeeld van de Filippijnen. Naar artikel 1 van de Grondwet verwees het voorstel niet alleen omdat men de band met het Koninkrijk wilde handhaven, maar ook omdat Soetardjo en andere Indonesiërs meenden dat de in 1922 ingevoerde nieuwe tekst van dat artikel meebracht, dat Nederlands-Indië binnen het Rijk ten opzichte van Nederland niet meer een ondergeschikte maar een nevengeschikte positie innam.

Het voorstel ging vergezeld van een uitvoerige toelichting. Vijf andere Volksraadsleden traden als mede-indieners op, namelijk Kasimo en Ratoelangie benevens een Minangkabauer, een Arabier en een Chinees. Volgens de toelichting had de historie van eeuwen de materiële en ideële belangen van Nederland en Nederlands-Indië dusdanig met elkaar verweven, dat een uiteengaan van deze landen ernstige gevolgen zou hebben. In het belang van de opbouw van beide landen was een innige en hartelijke samenwerking nodig. De daarvoor benodige bezieling zou alleen gewekt kunnen worden als men doelbewust en volgens een vooraf opgezet plan zou aansturen op een verhouding tussen Nederlands-Indië en het Moederland die kon voldoen aan de nationale, culturele, economische en staatkundige behoeften van dat deel van beide volken dat de door de historie geboden samenwerking aanvaardde.

De leden van de Nationale Fractie hadden gemengde gevoelens over dit voorstel. Een conferentie op voet van gelijkheid ter bespreking van de toekomstige verhouding tussen Nederland en Indonesië zou op zichzelf wel een belangrijke stap vooruit betekenen, maar het door Soetardjo aangegeven einddoel beantwoordde niet aan de door hen nagestreefde nationale onafhankelijkheid. Aan de andere kant ging dit einddoel de meeste Nederlandse Volksraadsleden juist veel te ver, zeker binnen de korte termijn van tien jaar. Ook enkele Indonesische leden hadden tegen die termijn bezwaar.

Het werd duidelijk dat het voorstel-Soetardjo in de Volksraad geen kans maakte als de woorden 'binnen tien jaar' in de ontwerp-petitie bleven staan. De indieners vervingen die woorden daarom door 'binnen zoodanige tijd als de conferentie voor de uitvoering van de gedachte mogelijk zal achten'. Van groot belang was, dat nu ook de fractie van het Indo-Europeesch Verbond bereid tot steun bleek. Op 29 september 1936 nam de Volksraad het aldus gewijzigde voorstel aan met 26 tegen 20 stemmen. Van de Nationale Fractie stemden zes leden voor (onder wie Thamrin, Koesoemo Oetojo en Iskandar Dinata) en vier leden tegen.

Soetardjo's voorstel had in het begin weinig publieke belangstelling ont- 
moet, maar dit werd anders toen de Volksraad de petitie eenmaal had vastgesteld en aan de koningin en het Nederlandse parlement had gezonden. Veel Indonesiërs wachtten met spanning af of Nederland de gevraagde conferentie bijeen zou willen roepen. Sommigen meenden dat zo'n conferentie in elk geval tot wederzijds begrip en vertrouwen zou kunnen bijdragen, ook al zou ze geen concrete resultaten boeken. Soetardjo en zijn mede-indieners publiceerden een brochure onder de titel Indonesië zelfstandig, met een uitvoerige uitleg en verdediging van hun initiatief. Toen een antwoord van Nederland uitbleef, vormden zij in oktober 1937 een centraal comité om actie te voeren ter beïnvloeding van de Nederlandse opstelling. Ook enige anderen namen plaats in dit comité, onder wie de bekende politici Agoes Salim en Sartono. Verscheidene Indonesische organisaties schaarden zich achter de actie. Onder de vleugels van het centrale comité belegden plaatselijke comités een groot aantal openbare bijeenkomsten waarin men er bij Nederland op aandrong de petitie in te willigen. De Parindra en de Gerindo steunden de actie niet, omdat zij wel instemden met het verzoek om een conferentie, maar niet met het in de petitie aangeduide einddoel.

De overgrote meerderheid van de Nederlanders in Indonesië ging niet of nauwelijks op de petitie-Soetardjo in, omdat men die onzinnig en onbehoorlijk vond. De zeer kleine Indische Sociaal-Democratische Partij was de enige Nederlandse organisatie die zich ten gunste van de petitie uitsprak.

Op aandrang van Soetardjo werd ook in Nederland een comité gevormd om actie te voeren voor inwilliging van de petitie. Het bekendste lid van dit comité was de vroegere voorzitter van de ISDP, ir. Cramer, die van 1918 tot 1923 in de Volksraad had gezeten (waar hij onder meer met Tjokroaminoto en Tjipto Mangoenkoesoemo had samengewerkt) en die van 1923 tot 1937 de Indonesië-expert van de SDAP in het Nederlandse parlement was geweest.

Eén van de redenen waarom de Nederlandse regering lange tijd niet op de petitie antwoordde, was dat zij wachtte op een advies van het NederlandsIndische gouvernement. Aan het hoofd hiervan stond nu A.W.L. Tjarda van Starkenborgh Stachouwer, die B.C. de Jonge in september 1936 was opgevolgd. De nieuwe gouverneur-generaal was commissaris van de koningin in Groningen en gezant in Brussel geweest, maar wist van Nederlands-Indië niets en had er ook nooit belang in gesteld. Al kort na de ontvangst van de Volksraadspetitie in Den Haag vroeg de regering hem hier advies over uit te brengen, maar hij maakte daar niet de minste haast mee.

Overigens bleek ook zonder officiële reactie, dat aan Nederlandse kant weinig bereidheid bestond om op de petitie-Soetardjo in te gaan. Hoewel de petitie uitging van handhaving van de rijkseenheid, stonden de koloniaalconservatieve kringen rondom de Utrechtse indologiefaculteit er volstrekt afwijzend tegenover. In februari 1937 kwam de petitie vrijblijvend in het parlement ter sprake bij de behandeling van de Indische begroting. Colijn noemde 
Nederlands-Indië nog lang niet rijp voor zelfstandigheid en vond daarbij zowel de christelijke als de liberale partijen aan zijn zijde. Alleen de SDAP en de CPN pleitten voor aanvaarding van de petitie. De kans op aanvaarding werd er niet beter op nadat in 1937 verkiezingen voor de Tweede Kamer hadden plaatsgevonden, want die gaven een verdere verschuiving naar rechts te zien. Colijn vormde een nieuw kabinet, waarin het departement van koloniën nu werd toebedeeld aan oud-minister Welter, tevens oud-voorzitter van de Ondernemersraad voor Nederlandsch-Indië. Welter toonde zich niet minder conservatief dan Colijn. Een nieuwe gedachtenwisseling over de petitie-Soetardjo tijdens de begrotingsbehandeling in 1938 leverde dan ook slechts een bevestiging op van de in 1937 ingenomen standpunten.

Wat het koloniaal beleid betreft, tekende de verschuiving naar rechts zich overigens niet alleen af in de verkiezingsresultaten van 1937, maar ook in de opstelling van de politieke partijen zelf. Verschillende christelijke en liberale partijen spraken zich uitdrukkelijker dan vroeger uit voor handhaving van de rijkseenheid. Ook de SDAP was opgeschoven. Sinds de maatregelen die de regering na de muiterij op De Zeven Provinciën tegen haar genomen had, was zij beducht geraakt voor de roep onvoldoende vaderlandslievend te zijn; ir. Cramer keerde in 1937 niet meer in het parlement terug. De CPN stelde zich minder scherp op in verband met de in 1935 door de Komintern afgekondigde 'Volksfrontpolitiek', die de communistische partijen voorschreef toenadering te zoeken tot sociaal-democraten en andere gematigd-linkse groeperingen teneinde een gezamenlijk front te vormen tegen de dreiging van fascisme en nationaal-socialisme. Wegens het Japanse gevaar drong de CPN niet langer aan op onmiddellijke onafhankelijkheid voor Indonesië en liet zij daarom aan het slot van haar leuze 'Indonesië los van Holland nu!' het woordje 'nu' vervallen. De nauw met de CPN samenwerkende Perhimpoenan Indonesia ging nog een stap verder en schrapte het laatste woord uit de titel van haar orgaan Indonesia Merdeka.

Colijn en Welter betoogden steeds dat Nederlands-Indië geen staatkundige hervormingen aan de top nodig had, maar dat voortgang naar meer zelfstandigheid allereerst op plaatselijk en regionaal niveau moest worden bevorderd. Daarbij was Colijn er voorstander van om sommige onder rechtstreeks bestuur staande gebieden buiten Java weer onder zelfbesturende vorsten te plaatsen. Tijdens zijn ministerschap werd een bescheiden begin gemaakt met zulk een herstel van inheemse vorstendommen, in de hoop daarmee de nationalistische beweging terug te dringen. De belangrijkste gebieden waar deze refeodalisering plaatsvond waren Zuid-Celebes in 1936 en Bali in 1938. Het Balinese lid van de Volksraad Soekawati, die zelf behoorde tot een oud vorstengeslacht, betwijfelde overigens of dit nieuwe zelfbestuur wel een stap vooruit betekende.

Op aandrang van het Nederlandse parlement zette de regering bovendien 
weer een stap op de weg naar het invoegen van een nieuwe bestuurslaag tussen het centrale gouvernement en de residenten. Medio 1938 kwamen nieuwe bestuurseenheden tot stand voor Sumatra, Borneo en de Grote Oost (een benaming voor heel Nederlands-Indië ten oosten van Java en Borneo), waarnaar bepaalde taken van het gouvernement werden overgeheveld. Deze nieuwe bestuurseenheden, elk onder een gouverneur, kregen geen belangrijke autonome bevoegdheden, evenmin als de tien jaar eerder op Java in het leven geroepen provincies. Het wekte aan Indonesische kant enige irritatie dat Nederland wel tot zulke bestuurshervormingen overging maar niet op de petitie-Soetardjo reageerde.

Toen de Volksraad na ruim twee jaar nog steeds geen antwoord op de petitie had ontvangen, stelde Soetardjo op 22 oktober 1938 schriftelijke vragen aan het gouvernement. Ongerustheid uitend over de internationale toestand wegens de koloniale verlangens van onder meer Duitsland en Japan, vroeg hij of het gouvernement zijn mening deelde, dat het met het oog hierop wenselijk was spoedig aan de petitie gevolg te geven. Tegelijk opperde hij dat dan na de voorgestelde conferentie een gezamenlijke verklaring zou worden uitgegeven waaruit de wil van de bevolking van Nederlands-Indië zou moeten blijken om integraal in het Nederlandse staatsverband te blijven.

Het gouvernement antwoordde hierop op 29 oktober dat het voor de hier bedoelde ongerustheid geen enkele grond aanwezig achtte, dat het dus het uitgangspunt van de vragen niet aanvaardde en dat het overigens van oordeel was, dat de wil van de bevolking van Nederlands-Indië om integraal in het Nederlandse staatsverband te blijven niet twijfelachtig was en geen bevestiging behoefde.

Anderhalve maand voordat Tjarda dit antwoord liet geven, had hij eindelijk zijn advies aan de Nederlandse regering uitgebracht. In overeenstemming hiermee stelde minister Welter nu aan de koningin voor, de petitie af te wijzen. Hij schreef daarbij dat men 'uit de aard der zaak' niet kon denken aan inwilliging van het verzoek van de Volksraad, 'noch zelfs aan enige poging om in de richting van dat verzoek een of meer bescheiden stappen te doen'. Binnen het kader van de bestaande staatsinstellingen was er immers voldoende ruimte voor krachtige uitgroei van de autonomie; elk toegeven aan 'overspannen verlangens of verwachtingen' zou de normale groei van het staatkundige leven in Indië belemmeren.

Op 16 november 1938 ondertekende koningin Wilhelmina het besluit tot afwijzing van de petitie. Dit besluit hield onder meer in, dat de petitie in haar formulering de klaarheid van doelstelling miste die door het gewicht van het daarin behandelde onderwerp geboden was, dat de bijeenroeping van een conferentie als in de petitie beoogd strijdig zou zijn met het geldende staatsrecht, dat de zelfstandigheid die Nederlands-Indië in het Nederlandse staatsbestel bezat of zou kunnen krijgen niet werd geregeld in artikel 1 van de 
Grondwet maar in de artikelen 62 tot en met 64, dat de bestaande grondwettelijke en wettelijke bepalingen ruimte boden voor verdere opbouw en vervollediging van autonomie op democratische grondslag en dat verhaasting van de ontwikkeling, al dan niet binnen een bepaalde termijn en al dan niet volgens een bepaald schema, niet in het belang van Nederlands-Indië zou zijn.

\section{Het eenheidsfront Gapi en de campagne 'Indonesië parlementair'}

In de jaren 1936-1938 trad het gouvernement iets minder repressief op dan in de jaren 1933-1935. Terwijl het merendeel van de uit de samenleving verwijderde politici in Boven-Digoel geïnterneerd bleef, werden Hatta en Sjahrir in 1936 naar de Banda-eilanden overgebracht. Zij deelden dit ballingsoord met twee andere voormannen van de nationale beweging. Eén van hen was Tjipto Mangoenkoesoemo, nationalist van het eerste uur, die hier al acht jaar geïnterneerd zat. De ander was Iwa Koesoema Soemantri, een oud-voorzitter van de Perhimpoenan Indonesia die na zijn studie in Nederland een tijd lang in Moskou verbleven had, door het gouvernement als een communistische intrigant werd gezien en in 1930 naar Banda verbannen was. Intussen verkeerde Soekarno op Flores in een veel ernstiger isolement. In 1938 besloot het gouvernement zijn situatie te verlichten door hem te interneren in Benkoelen aan de westkust van Sumatra. Tjipto, wiens gezondheid sterk achteruitging, werd eind 1939 naar Makassar overgebracht.

De aanhang van de Indonesische vrijheidsbeweging viel moeilijk te peilen, nu alle politieke manifestaties verboden waren. Maar dat Soekarno nog steeds grote faam genoot, ook buiten Java, bleek toen hij in maart 1938 per trein door Zuid-Sumatra naar zijn nieuwe ballingsoord werd gebracht: de plaatselijke bevolking verzamelde zich bij de stations om hem eer te bewijzen. Enige maanden later werd Soerabaja het toneel van een andere demonstratie van politieke betrokkenheid toen Soetomo, slechts vijftig jaar oud, onverwacht overleed: aan de uitvaart van deze grote pionier van de nationale beweging namen vijftigduizend mensen deel.

Niettemin schreef minister Welter in november 1938 aan koningin Wilhelmina over de politieke situatie in Indonesië onder meer: 'Verlangens naar staatkundige zelfstandigheid leven nog slechts bij een uiterst dunne laag van meer-ontwikkelden'.

Intussen was de nationale beweging bezig zich te herstellen van de ontreddering die de scherpe repressie teweeg had gebracht. De negatieve Nederlandse reactie op de petitie-Soetardjo versterkte het besef van saamhorigheid aan Indonesische kant. Begin 1939 zorgde de regering voor verdere teleurstelling door tot voorzitter van de nieuwe Volksraad alweer geen Indonesiër te benoemen. Zowel de Volksraad als de gouverneur-generaal had hiervoor Hoesein Djajadiningrat aanbevolen, die sinds 1935 het enige Indonesische lid van de 
Raad van Indië was. Als tweede en derde keus had de Volksraad Moelia en Jonkman aanbevolen. De regering benoemde Jonkman. De Volksraad zelf koos Thamrin tot vice-voorzitter.

De herlevende politieke belangstelling werd in deze tijd ook bevorderd door andere ontwikkelingen. Het dieptepunt van de economische crisis was voorbij, de werkgelegenheid nam toe. Modern opgezette organisaties, zoals jeugdbonden en vrouwenbonden, groeiden in aantal en omvang; het alfabetisme en de kennis van de Nederlandse taal verbreidden zich in hoog tempo, vooral dank zij de wilde scholen. De Indonesische pers had honderdduizenden lezers. Daarnaast speelden sinds 1938 ook twee Nederlandstalige periodieken een stimulerende rol. Eén daarvan was Nationale Commentaren, geleid door Ratoelangie, die inmiddels geen lid van de Volksraad meer was. Het andere was Kritiek en Opbouw, opgericht door de Nederlandse socialist D.M.G. Koch. Dit was voor het eerst sinds het verdwijnen van De Stuw weer een blad onder Nederlandse leiding dat zich stelselmatig tegen het koloniale conservatisme keerde.

Terwijl de in 1927 door Soekarno gestichte federatie PPPKI de scherpe repressie niet overleefd had, besloten verschillende politieke groeperingen nu opnieuw een samenwerkingsverband tot stand te brengen. Dit verband werd in mei 1939 opgericht onder de naam Gaboengan Politik Indonesia (Indonesische Politieke Federatie), kortweg Gapi genoemd. Haar beginselverklaring sprak niet van onafhankelijkheid maar wel van nationale eenheid, democratie en zelfbeschikkingsrecht. Tot de deelnemende organisaties behoorden onder meer de Parindra, de Gerindo, de Sarekat Islam, de Pasoendan en ook Ratoelangie's Minahasa-bond en Kasimo's katholieke partij, die destijds niet aan de PPPKI hadden meegedaan. De dagelijkse leiding berustte bij een driemanschap bestaande uit Thamrin (Parindra), Amir Sjarifoeddin (Gerindo) en Abikoesno (Sarekat Islam). De Gapi trad actief op als eenheidsfront van de nationale beweging. Zij kondigde onder meer aan een Indonesisch Volkscongres te zullen beleggen.

De grotere bereidheid van Indonesische politici tot onderlinge samenwerking werd ook beïnvloed door de gespannen internationale situatie. In OostAzië voerde Japan al jarenlang oorlog met China. In 1936 had het een politiek pact met Duitsland gesloten en Italië had zich daarbij aangesloten; men noemde dit de As Berlijn-Rome-Tokio. Het was duidelijk dat de As-mogenheden op expansie uit waren. Italië had zich al meester gemaakt van Abessinië, de laatste grote onafhankelijke staat in Afrika. Met hulp van Duitsland en Italië won generaal Franco de in 1936 door hem begonnen burgeroorlog in Spanje. In maart 1938 lijfde Duitsland Oostenrijk in. In september werd Tsjechoslowakije tot gebiedsafstand aan Duitsland gedwongen; niettemin maakte Duitsland in maart 1939 alsnog een eind aan de Tsjechoslowaakse onafhankelijkheid. De bezorgdheid onder Indonesische intellectuelen voor het gevaar, dat Japan zou 
proberen Indonesië in zijn macht te krijgen, werd nu nog vergroot door de vrees dat Nederland in de greep van Duitsland zou komen.

De in de Gapi samenwerkende organisaties besloten een grote campagne te gaan voeren onder de leuze 'Indonesia berparlemen' ('Indonesië voorzien van een parlement' ofwel 'Indonesië parlementair'). Zowel voorstanders van volledige onafhankelijkheid als voorstanders van behoud van een band met Nederland konden zich scharen achter de doelstelling van deze campagne: de instelling van een uit en door de bevolking gekozen parlement met een daaraan verantwoordelijke regering. Deze doelstelling kwam overeen met wat al in 1918 door de Radicale Concentratie in de Volksraad was bepleit; zij lag bovendien in de lijn van wat de commissie-Carpentier Alting al in 1920 had voorgesteld.

In september 1939 lanceerde de Gapi de campagne formeel met een manifest. De Tweede Wereldoorlog was toen al begonnen met de Duitse inval in Polen en de daarop gevolgde oorlogsverklaringen van Frankrijk en GrootBrittannië aan Duitsland. Volgens het Gapi-manifest was samenwerking tussen het Indonesische volk en het Nederlandse volk gewenst, omdat de internationale gebeurtenissen een steeds groter gevaar vormden voor de veiligheid van het gezag in Nederlands-Indië en voor de Indonesische maatschappij. Met het oog daarop zou het Indonesische volk nieuwe rechten moeten krijgen door de instelling van een volwaardig parlementair stelsel. Als hieraan voldaan werd, zou de Gapi bereid zijn het Indonesische volk op te wekken tot het verlenen van de meest uitgebreide steun.

Het gouvernement beschouwde deze voorwaarde als chantage en waarschuwde Ratoelangie en Thamrin onmiddellijk, dat zij en hun organisatie zich moesten hoeden voor het wekken van de indruk dat men aan het gouvernement wensen onder bedreiging voorlegde.

Overigens omvatten de wensen van de Gapi niet méér dan Amerika al in 1916 aan het Filippijnse volk gegund had. Omdat Thamrin er niet op vertrouwde dat Nederland Indonesië tegen Japan zou kunnen beschermen, vestigde hij zijn hoop nu in de eerste plaats op de Verenigde Staten. In oktober 1939 brachten Thamrin, Ratoelangie en Soetardjo in het diepste geheim een bezoek aan het Amerikaanse consulaat. Zij stelden daar voor dat, indien Nederland door Duitsland bezet zou worden en niet langer als een onafhankelijke staat zou voortbestaan, Amerika een protectoraat over Indonesië zou vestigen, dat bij referendum aan de goedkeuring van het Indonesische volk onderworpen zou worden. De Amerikaanse regering ging niet op dit voorstel in.

De actie 'Indonesië parlementair' kreeg zeer veel steun. De federatie van vakbonden van inheems overheidspersoneel sloot zich erbij aan, evenals de Hoge Islamitische Raad van Indonesië (MIAI), die zich meer en meer op politiek terrein begon te bewegen. Ook Soetardjo stelde zich erachter. Overal, zowel binnen als buiten Java, werden plaatselijke actiecomités gevormd. In december belegde de Gapi in Batavia het al aangekondigde Indonesische 
Volkscongres. Negentig verenigingen namen eraan deel. Het congres ondersteunde niet alleen de actie voor een nationaal parlement, maar besloot ook tot aanvaarding van de roodwitte vlag als Indonesische eenheidsvlag, van de Bahasa Indonesia als eenheidstaal en van het 'Indonesia Raja' als eenheidslied. Het noemde zijn vergaderplaats niet Batavia, maar Djakarta.

De Nederlandstalige dagbladen schonken weinig aandacht aan de activiteiten van de Indonesische nationale beweging. Het Nederlands-Indische persbureau Aneta had zelfs het Gapi-manifest van september niet gepubliceerd. De in de Gapi samenwerkende organisaties richtten nu een eigen persbureau op onder de naam Antara.

Minister Welter had eerder verklaard dat zelfstandigheid van NederlandsIndië binnen het rijksverband het doel van Nederland's koloniale politiek was, maar de zelfstandigheid die hij bedoelde was niet dezelfde als die beoogd werd met de actie voor een parlementair Indonesië. In zulk een Indonesië zou de dienst immers niet door Nederlanders maar door Indonesiërs worden uitgemaakt. Het verontrustte Welter dat ook de vakbonden van inheems overheidspersoneel zich achter de actie schaarden. Hij wilde de Gapi-campagne dan ook het liefst een halt toeroepen voordat het te laat was. Meyer Ranneft, die na zijn pensionering naar Nederland teruggekeerd was, schreef dat de actie streefde naar ontwrichting van de bestaande orde.

Intussen was in augustus 1939 een nieuw Nederlands kabinet aangetreden, waar nu ook twee voormannen van de SDAP deel van uitmaakten, maar waarin Welter minister van koloniën gebleven was. In februari 1940 kwam de Gapi-campagne ter sprake in het Nederlandse parlement. Welter verklaarde dat er geen sprake zou kunnen zijn van een aan een Indisch parlement verantwoordelijke Indische regering, zolang de Nederlandse verantwoordelijkheid voor Nederlands-Indië in stand zou blijven. De SDAP-fractie gaf geen steun aan de actie van de Gapi. Wel diende zij een motie in waarin de regering werd uitgenodigd de mogelijkheid te onderzoeken van toekenning van ruimere staatkundige bevoegdheden aan Nederlands-Indië. Het parlement verwierp deze motie met grote meerderheid.

Overigens was de politieke repressie in de kolonie sinds het begin van 1939 weer verscherpt. Dat organisaties als de Parindra en de Gerindo zich op coöperatie-standpunt stelden, vrijwaarde hen niet van streng politie-optreden. De politie greep veelvuldig in tijdens politieke bijeenkomsten; herhaaldelijk werden vergaderingen ontbonden en werden sprekers gerechtelijk vervolgd. Het gouvernement kon echter het streven naar een parlement voor Indonesië moeilijk verbieden en de Gapi ging dan ook door met haar campagne. In maart 1940 bestonden er al ongeveer honderdendertig comités in het kader van de actie 'Indonesië parlementair'. De actieleiders wilden dit aantal in de loop van het jaar verveelvoudigen, maar het uitbreken van de oorlog met Duitsland doorkruiste deze plannen. 
Toen in 1939 de Tweede Wereldoorlog uitbrak, waren bijna vier decennia verstreken sinds de Nederlandse regering in 1901 een wijziging van het koloniaal beleid had verkondigd die ervan uitging dat Nederland tegenover de bevolking van Nederlands-Indië een zedelijke roeping te vervullen had (de 'ethische politiek'). Op de weg naar maatschappelijke emancipatie van de inheemse bevolking waren sindsdien slechts bescheiden vorderingen gemaakt. Het koloniale bestel was in 1940 nog steeds gebaseerd op het onderscheid tussen Inlanders en Europeanen, dat voor de Indonesiërs verschillende vormen van rechtsongelijkheid en achterstelling meebracht (zie pp. 132-3). Dit was een bron van frustratie en ergernis voor alle ontwikkelde Indonesiërs, ook voor hen die de band met Nederland wilden handhaven. Wat bijvoorbeeld de rechtsbedeling betreft, kwamen zaken tegen Europeanen in de regel voor andere rechterlijke organen dan zaken tegen Indonesiërs. Terwijl tal van Nederlandse rechters aan de berechting van Indonesiërs deelnamen, werden Indonesiërs bijna nooit tot rechter benoemd bij organen die Europeanen berechtten. Op het gebied van huiszoeking, voorarrest en bewijsvoering genoten Europese verdachten bepaalde waarborgen die niet voor Indonesische verdachten golden. De Nederlandse wetgeving kende aan Indonesiërs niet de Nederlandse nationaliteit toe, maar maakte hen tot tweederangsburgers als 'Nederlandse-onderdanen-niet-Nederlanders'.

Terwijl de Britse autoriteiten bij het Brits-Indische bestuurskorps steeds meer inheemse Indiërs aanstelden, liet Nederland nog steeds geen Indonesiërs toe tot het centrale deel van het Binnenlands Bestuur, het Europese korps. Wat andere bestuursfuncties betreft, bekleedden Indonesiërs slechts zelden betrekkingen waarin zij Nederlanders als ondergeschikten hadden. Westerse ondernemingen benoemden Indonesiërs niet in leidende posities. Kortom, evenals in de negentiende eeuw kregen Indonesiërs verantwoordelijke functies vrijwel alleen als leden van het Inlandse korps van het Binnenlands Bestuur of als feodale zelfbestuurders. Onder het hoger personeel in dienst van het gouvernement liep het percentage van de Indonesiërs omstreeks 1940 zelfs terug.

Er waren enkele uitzonderingen. In 1939 werd voor het eerst een Indonesiër tot burgemeester benoemd, namelijk van de Oost-Javaanse stad Madioen; in 1941 kreeg ook Buitenzorg een Indonesische burgemeester. Hoesein Djajadiningrat, die vijf jaar lang lid van de Raad van Indië geweest was, werd in 1940 aangesteld als hoofd van het departement van onderwijs en eredienst; daarmee kreeg voor het eerst een Indonesiër de leiding over een departement van het centrale bestuur. Zijn opvolger in de Raad van Indië werd Soejono, oud-regent en oud-lid van de Volksraad. In mei 1941 benoemde de regering Hoesein Djajadiningrat opnieuw tot lid van de Raad van Indië, die nu dus eindelijk weer twee Indonesische leden ging tellen. Hoesein's broer Loekman 
Djajadiningrat volgde hem op als directeur van onderwijs en eredienst.

De sociale kloof tussen de Indonesische en de Nederlandse bevolking van de kolonie was tegen 1940 wijder geworden dan ooit tevoren. Nog nooit was een zo groot deel van de Nederlandse ingezetenen in Nederland zelf opgegroeid; nog nooit waren er zoveel volledig Nederlandse echtparen en gezinnen geweest. De blanke bevolking woonde nu grotendeels in aparte villawijken in de steden en beperkte haar sociale omgang gewoonlijk tot de eigen kring. Zij beschikte over eigen clubs, zwembaden en tennisbanen, waar Indonesiërs meestal niet welkom waren. Veel westerlingen kenden Indonesiërs alleen als personeel. Het kwam zelden voor dat Nederlanders op voet van gelijkheid met Indonesiërs omgingen.

Ook op dit patroon bestonden uitzonderingen. De socialist D.M.G. Koch bijvoorbeeld, die zowel lid was geweest van de commissie-Carpentier Alting als van de Bandoengse Studieclub en die in 1938 het blad Kritiek en Opbouw oprichtte, telde ook radicale nationalisten onder zijn vrienden. Jonkman, de voorzitter van de Volksraad, onderhield goede betrekkingen met enige Indonesiërs die hij in Nederland in het Indonesisch Verbond van Studeerenden had leren kennen, onder wie Ki Hadjar Dewantoro, Moelia en Ratoelangie; bovendien genoot hij het vertrouwen van Thamrin. Ter bevordering van een 'Indische' cultuur waaraan alle bevolkingsgroepen deel zouden kunnen hebben richtte P.J. Koets, leraar en oud-secretaris van de Stuw-groep, eind 1940 het maandblad De Fakkel op dat zowel Nederlandse als Indonesische redacteuren had. Een ander oud-lid van de Stuw-groep dat probeerde de verschillende bevolkingsgroepen nader tot elkaar te brengen was de arabist Ch.O. van der Plas, sinds 1936 gouverneur van Oost-Java. Hij gold als een kenner zowel van de islam als van verschillende Indonesische talen en culturen en had veel Indonesische contacten, vooral in de kringen van de ambtsaristocratie. Juist wegens die contacten werd hij in mei 1941 tot lid van de Raad van Indië benoemd.

\section{Nederland in oorlog met Duitsland}

Nederland bleef in de Tweede Wereldoorlog eerst neutraal, maar daar kwam op 10 mei 1940 een eind aan toen Duitsland het land binnenviel. Na vijf dagen moest het Nederlandse leger de strijd opgeven en begon de Duitse bezetting van Nederland. Koningin Wilhelmina en haar ministers waren intussen naar Londen gegaan en vormden nu een regering in ballingschap.

Voor de Nederlandse ingezetenen van Indonesië betekende de val van het moederland een geweldige schok. Zij schaarden zich massaal achter het gouvernement. Ook veel Indonesische organisaties riepen hun leden op tot loyale steun aan het Nederlands-Indische gezag. Niettemin bleef een groot deel van de Indonesische bevolking vrij onverschillig. De Indonesiërs die 
zich het lot van Nederland het meest aantrokken waren vooral zij die een westerse opleiding gevolgd hadden; daartoe behoorden ook vooraanstaande nationalisten. Onmiddellijk na de Duitse inval kreeg het gouvernement steun van de twee Indonesische voormannen die zich in 1912 als eersten voor onafhankelijkheid voor Indonesië hadden uitgesproken: Soewardi Soerjaningrat en Tjipto Mangoenkoesoemo. Soewardi, nu als Ki Hadjar Dewantoro leider van de Taman Siswa-scholen, zond een boodschap aan gouverneur-generaal Tjarda waarin hij zich solidair met Nederland verklaarde. Tjipto, sinds 1927 geïnterneerd, publiceerde een oproep aan de nationale beweging om zich naast Nederland op te stellen tegenover het Japanse gevaar. Het gouvernement reageerde niet op hun solidariteitsbetuigingen.

Sinds 10 mei 1940 gold in Nederlands-Indië de staat van beleg. Alle openbare politieke vergaderingen werden verboden; voor besloten politieke vergaderingen was voortaan toestemming van het bestuur vereist. Er kwam censuur op het particuliere berichtenverkeer.

Verder ging het gouvernement op 10 mei over tot de arrestatie en internering van alle Duitse mannen die zich in de kolonie bevonden, bijna 2800 in totaal. Tot hen behoorden ook personen die geen enkele band met het nazi-regime hadden, onder wie joodse Duitsers, missionarissen, zendelingen, gepensioneerde gouvernementsdienaren en Indo-Europeanen die zelfs geen Duits kenden. Vooral in het begin werden veel gearresteerden slecht behandeld. Het gouvernement hield de Duitsers eerst op verschillende plaatsen in de archipel gevangen; later bracht het hen over naar een speciaal daarvoor gebouwd interneringskamp in Noord-Sumatra. Naast de Duitsers werden in mei 1940 ook andere Europeanen gearresteerd die van sympathie voor de vijand werden verdacht, onder wie ruim vijfhonderd Indische NSB'ers. De meesten hiervan werden op Java gevangen gehouden.

$\mathrm{Nu}$ Nederland door Duitsland bezet was, verwachtten Tjarda en vele anderen dat de regering naar Nederlands-Indië zou verhuizen. Die verwachting vond ook steun in artikel 21 van de Grondwet dat bepaalde: 'In geen geval kan de zetel der Regeering buiten het Rijk worden verplaatst'. In overeenstemming daarmee stelden de ministers in juni 1940 aan de koningin voor om de regeringszetel in Bandoeng te vestigen. Koningin Wilhelmina, die de kolonie tijdens de ruim veertig jaar van haar koningschap nog nooit had willen bezoeken en ook niet gewild had dat de kroonprinses er een bezoek bracht, wees dit af. In de Volksraad vroegen Thamrin en Yamin (die in 1939 tot lid gekozen was) of de vestiging van de regering in Londen wel te rijmen viel met de Grondwet; het gouvernement antwoordde dat de regering haar zetel niet verplaatst had, maar alleen tijdelijk haar functies elders uitoefende. Overigens brachten de minister van koloniën Welter en de minister van buitenlandse zaken E.N. van Kleffens in het voorjaar van 1941 een bezoek van enige weken aan Nederlands-Indië. 
In de nieuwe situatie als gevolg van de Duitse bezetting van Nederland stond het gouvernement voor de taak het hoofd te bieden aan de Japanse dreiging. In Japan werd al enige tijd verkondigd dat dit land in Oost-Azië een 'sfeer van gemeenschappelijke welvaart' tot stand moest brengen die niet alleen Japan en China zou omvatten maar ook de Filippijnen, Indonesië en AchterIndië (Indochina, Thailand, Birma en Malakka). Al kort nadat Nederland bezet was, vroeg de Japanse regering het gouvernement om grote leveringen van aardolie en bauxiet (twee grondstoffen die Japan tot dan tot voornamelijk uit de Verenigde Staten betrok). Tegelijk stelde zij voor algemene onderhandelingen te voeren over de betrekkingen tussen Japan en Nederlands-Indië. Deze onderhandelingen begonnen in september 1940 in Batavia. Van Mook, die sinds 1937 directeur van het departement van economische zaken was, leidde de Nederlandse delegatie; ook Hoesein Djajadiningrat was deel van de delegatie. De Japanse onderhandelingsdelegatie werd geleid door een minister van handel. De besprekingen gingen in hoofdzaak over allerlei grondstoffen, maar de Japannners verlangden ook dat het gouvernement zou optreden tegen antiJapanse artikelen in de Nederlands-Indische pers. Omdat het gouvernement weinig aan de Japanse wensen tegemoetkwam, keerde de Japanse delegatieleider na een maand naar Tokio terug.

Intussen werd de situatie steeds dreigender. Na de nederlaag van Frankrijk was daar een nieuwe regering gevormd die aan de macht van Duitsland onderworpen was maar door het bestuur van de Franse kolonie Indochina gehoorzaamd werd. Dit bestuur verzette zich niet toen Japanse troepen in september 1940 het noorden van Indochina bezetten. De Japanse regering zei openlijk dat Indochina én Indonesië tot de sfeer van gemeenschappelijke welvaart behoorden en dat hun betrekkingen met Japan daarom grondig veranderd moesten worden. De Japanse pers beschuldigde het NederlandsIndische gouvernement van tegenwerking. Eind december arriveerde in Batavia een nieuwe Japanse delegatieleider, een oud-minister van buitenlandse zaken. Naast economische wensen legde Japan nu ook tal van politieke verlangens op tafel; onder meer zou Nederlands-Indië zich in een politieke verklaring aan de kant van Japan moeten opstellen. Het gouvernement liet zich niet intimideren en wees na vijf maanden onderhandelen vrijwel alle eisen af, waarop Japan de besprekingen beëindigde. De bekwame manier waarop Van Mook de onderhandelingen gevoerd had kwam zijn reputatie in de kolonie zeer ten goede.

Eind juli 1941 bezette Japan het zuiden van Indochina. De Verenigde Staten en Groot-Britannië reageerden hierop met een algeheel embargo op de uitvoer naar Japan. De Nederlandse regering in Londen sloot zich daarbij aan. 


\section{De defensiecapaciteit van Nederlands-Indië}

De taak om Nederlands-Indië tegen buitenlandse aanvallen te verdedigen was toevertrouwd aan het koloniale leger en aan het in de kolonie gestationeerde deel van de Nederlandse marine. Het opperbevel over deze strijdkrachten berustte krachtens de Indische Staatsregeling bij de gouverneur-generaal; onder hem stonden de commandant landmacht (de legercommandant van het KNIL) en de commandant zeemacht-in-Indië. Als Japan zich met militair geweld zou willen verschaffen wat het met politieke druk niet van NederlandsIndië had kunnen verkrijgen, zouden deze strijdkrachten niet in staat zijn de kolonie zelfstandig te verdedigen.

Sinds de Japanse overwinning op Rusland in 1905 waren alle Nederlandse plannen voor de verdediging van de kolonie altijd uitgegaan van één mogelijke agressor: Japan. Voor 1914 had men er nog over gedacht de externe defensie van de kolonie te verzekeren door de opbouw van een grote zeemacht die tegen een Japanse invasievloot opgewassen zou zijn, maar die gedachte was weer snel verlaten. Regering en parlement waren het er over eens dat Nederland te klein was om het reusachtige gebied van zijn Aziatische kolonie op eigen kracht te kunnen verdedigen. Tegelijk waren zij ervan overtuigd dat Nederland in die verdediging nooit alleen zou staan, want dat een Japanse aanval altijd ook Groot-Brittannië in de oorlog zou betrekken en wellicht ook Frankrijk en de Verenigde Staten. De externe defensietaak van de Nederlandse strijdkrachten werd daarom teruggebracht tot het vertragen van een aanval en het toebrengen van zo veel mogelijk schade aan de aanvaller in afwachting van bijstand door anderen. De verwerping van de ontwerp-vlootwet in 1923 beperkte de mogelijkheden nog verder. Pas in de jaren dertig kwam er meer vaart in de opbouw van de Nederlandse marine. In 1940 beschikte die marine in de Nederlands-Indische wateren over drie kruisers, een dertigtal kleinere oppervlakteschepen, vijftien onderzeeboten en ongeveer vijftig vliegtuigen.

Wat de landstrijdkrachten betreft, was het koloniale leger traditioneel noch uitgerust noch geoefend voor oorlogvoering tegen een modern bewapende buitenlandse vijand. Na de afronding van het koloniale rijk was het een politieleger geworden; hiervan bevond zich de helft op Java en de andere helft in de buitengewesten. In de jaren twintig besloot de regering het leger op Java ook een taak te geven voor de externe verdediging: het zou in staat moeten zijn een buitenlandse aanval van ongeveer vierduizend man af te slaan. Van de uitvoering van dit plan kwam in de crisisjaren weinig terecht. Als gevolg van radicale bezuinigingen zakte de sterkte van het KNIL tot minder dan 31.000 man. De zwakte van de externe defensie wekte vooral onder Europeanen verontrusting. Jaar na jaar nam de Volksraad moties aan waarin op versterking van de defensie werd aangedrongen. In 1937 verzamelde de Vaderlandsche Club zelfs 84.000 
handtekeningen onder een petitie van dezelfde strekking aan het Nederlandse parlement. Omstreeks diezelfde tijd begon het gouvernement meer geld voor de defensie beschikbaar te stellen. De sterkte van het KNIL steeg weer boven de 40.000 man, tanks en pantserwagens werden aangeschaft en men maakte een begin met de vorming van gemotoriseerde eenheden. Bovendien kreeg het KNIL de beschikking over meer vliegtuigen, waaronder honderd bommenwerpers en jagers. Buiten Java bleef het een licht bewapend politieleger.

Het KNIL was een beroepsleger dat voor een kwart uit Europeanen en voor driekwart uit Indonesiërs bestond. Daarnaast was in 1917 in Nederlands-Indië dienstplicht voor Nederlanders ingevoerd. In 1940 waren er in de kolonie tienduizenden dienstplichtige Nederlanders die enige militaire oefening hadden ontvangen; zij werden overigens voorlopig niet gemobiliseerd. Verder beschikte het gouvernement nog over diverse lokale hulpkorpsen, maar die waren voor de externe verdediging niet relevant.

Nadat Nederland door Duitsland bezet was, spande het gouvernement zich krachtig in om de defensie te versterken. Het bestelde in de Verenigde Staten honderden tanks, pantserwagens en vliegtuigen, tienduizenden geweren en grote hoeveelheden munitie. Maar de Amerikaanse oorlogsindustrie had toen nog pas een beperkte omvang en moest in de eerste plaats voorzien in de defensiebehoeften van Amerika zelf en van Groot-Brittannië, zodat slechts een zeer klein deel van het bestelde werd geleverd. Intussen vond er ook in de kolonie zelf militaire productie plaats, onder meer van kleine marineschepen, zeemijnen en munitie. Verder werden militaire versterkingen en vliegvelden aangelegd, ook in de buitengewesten. Legereenheden werden overgebracht naar twee aardoliecentra in Oost-Borneo die wellicht het eerste doelwit van een Japanse aanval zouden vormen. Omdat de officiersopleiding in Nederland weggevallen was, kreeg het KNIL nu een eigen officiersopleiding in de vorm van een Koninklijke Militaire Academie in Bandoeng, terwijl in Soerabaja een officiersopleiding voor de marine werd gevestigd.

Hoewel de Nederlandse plannen voor de verdediging van Indonesië al heel lang uitgingen van Brits-Nederlandse samenwerking, had de neutraliteitspolitiek tot 1940 belet over zulke militaire samenwerking overleg met de Britten te voeren. Dit beletsel was vervallen sinds Nederland door de Duitse inval een bondgenoot van Groot-Brittannië geworden was. Van het najaar van 1940 af vonden in Zuidoost-Azië besprekingen plaats tussen vertegenwoordigers van de Britse, de Australische en de Nederlandse strijdkrachten; in het voorjaar van 1941 gingen ook Amerikaanse vertegenwoordigers hieraan deelnemen. De in Singapore gestationeerde Britse vloot was overigens kleiner dan de Nederlandse zeemacht in de Indische wateren. Het in de Filippijnen gestationeerde deel van de Amerikaanse marine was weliswaar iets sterker, maar beschikte evenals de Britse en de Nederlandse vloot niet over slagschepen, slagkruisers of vliegkampschepen. Daarentegen maakten zulke zware 
oorlogsschepen wel deel uit van de Amerikaanse Pacific-vloot, die haar basis had in Pearl Harbor op de Hawaii-eilanden.

De Europese gemeenschap in Indonesië was vervuld van een krijgshaftige geest en bracht vrijwillig grote bedragen bijeen voor militaire aanschaffingen. De pers berichtte voortdurend over de paraatheid van de strijdkrachten en wekte de indruk dat de kolonie tot de tanden bewapend was. Die indruk was onjuist; in het bijzonder de landmacht was zwak in omvang en bewapening, had weinig artillerie en zeer weinig luchtafweergeschut. Dat de externe defensie van Nederlands-Indië ontoereikend was, had overigens niet zozeer een financiële als wel een politieke reden. Nederland had het steeds politiek te riskant gevonden om de inheemse bevolking massaal te betrekken bij de verdediging van de archipel. Pas in het midden van 1941 werd een vorm van dienstplicht voor Indonesiërs ingevoerd, maar dit betrof slechts een paar duizend man en droeg niet wezenlijk tot de defensie bij.

De door de pers bevorderde overdreven voorstelling van het defensieve vermogen van Nederlands-Indië droeg ertoe bij dat veel Europese ingezetenen de verdediging tegen een Japanse aanval allerminst kansloos achtten. Voor een deel lieten zij zich daarbij leiden door rationele overwegingen: zij dachten dat Japan maar een beperkte strijdmacht tegen Indonesië zou kunnen inzetten omdat het grootste deel van zijn leger gebonden was door de zich voortslepende oorlog in China, en zij dachten dat de Japanse marine te kampen zou hebben met lange verbindingslijnen die een gemakkelijk doelwit zouden vormen voor de Amerikaanse vloot. Maar voor een deel lieten zij zich ook leiden door racistische vooroordelen. Zo zei men dat Japanners niet goed in staat waren om vliegtuigen te besturen en om geschut te richten. Meer in het algemeen was men ervan overtuigd, dat Japanners weliswaar knap waren in het nabootsen van westerse voorbeelden maar dat zij niet over eigen creativiteit beschikten. Dezelfde vooroordelen leefden ook sterk aan Britse, Amerikaanse en Australische kant.

Bij de inheemse ingezetenen van Indonesië speelden zulke vooroordelen geen rol. Hoewel ook zij vaak een overdreven voorstelling hadden van de defensiecapaciteit van de kolonie, geloofden velen tegelijk in de onoverwinnelijkheid van Japan. Op Java werd dat geloof bovendien gestimuleerd door de Djojobojo-profetie die verkondigde dat een volk van gele huidskleur de blanke overheersers zou verslaan, maar dat de inheemse bevolking spoedig daarna baas in eigen huis zou worden.

\section{Bevriezing van het koloniale bestel}

In de eerste tijd nadat Nederland door Duitsland bezet was verwachtten veel ontwikkelde Indonesiërs een toenadering tussen de Nederlandse overheersers 
en de inheemse bevolking van de kolonie. Zij dachten dat de Nederlanders het Indonesische vrijheidsstreven beter zouden begrijpen nu hun eigen moederland onder vreemde overheersing was komen te staan. Bovendien hadden veel Indonesische organisaties zich in reactie op de Duitse overval solidair met Nederland verklaard; daar waren zelfs nationalistische partijen bij als de Parindra en de Sarekat Islam. Men verwachtte dat het gouvernement zich voortaan welwillender zou opstellen tegenover de nationale beweging. Het zou misschien het interneringskamp in Boven-Digoel opheffen of op zijn minst een eind maken aan de internering van de niet-communistische nationale leiders. In het bijzonder hoopte men op stappen van het gouvernement tot verkleining van de achterstelling van de inheemse onderdanen en tot vergroting van hun zeggenschap over het bestuur van het land.

Het optreden van het gouvernement beantwoordde niet aan deze verwachtingen. Boven-Digoel bleef bestaan. Ook de internering van Hatta, Sjahrir en Soekarno bleef gehandhaafd, hoewel zij in de nu woedende wereldoorlog de kant van de democratieën tegenover de dictaturen hadden gekozen. Wel beëindigde het gouvernement in oktober 1940 de internering van Tjipto Mangoenkoesoemo, maar die was te zeer verzwakt om na zijn terugkeer op Java nog een actieve politieke rol te kunnen spelen. Tot stappen ter verandering van het bestaande koloniale bestel was het gouvernement niet geneigd, evenmin als de regering in Londen. Gouverneur-generaal Tjarda verklaarde al in juni 1940 dat discussies over wijziging van staat en maatschappij beter konden blijven rusten tot na de oorlog.

Dit 'politieke moratorium' stelde de politiek bewuste Indonesiërs teleur. De Gapi zond daarom een telegram aan de koningin in Londen, dat aandrong op hervorming van de Volksraad tot een parlement waarvan de leden uit en door het volk gekozen zouden worden en waaraan de hoofden van de departementen verantwoordelijk zouden zijn. De Gapi gaf hier veel publiciteit aan en vroeg om schriftelijke betuigingen van instemming. Zij kreeg daarop schriftelijke bijval van meer dan tweehonderd Indonesische organisaties en meer dan twintigduizend individuele Indonesiërs. De regering in Londen liet het telegram onbeantwoord.

Enkele Nederlands-Indische kranten en tijdschriften betreurden de negatieve houding van het gouvernement tegenover de Indonesische nationale beweging. Zij meenden dat men een kans gemist had door met geen enkele tegemoetkoming te reageren op de solidariteit die van die kant jegens Nederland aan de dag was gelegd.

De kwestie van wijziging van het koloniale bestel kwam overigens in augustus 1940 uitgebreid in de Volksraad aan de orde bij de behandeling van drie moties die al dateerden van voor de bezetting van Nederland. De belangrijkste daarvan was in februari ingediend door het lid Wiwoho, samen met Kasimo en Soekawati. De motie-Wiwoho pleitte niet voor onafhankelijk- 
heid maar combineerde de gedachten van de vroegere petitie-Soetardjo met die van de campagne 'Indonesië parlementair'. De motie verzocht het gouvernement onder meer zich er bij de regering van het Koninkrijk voor in te zetten, dat Nederlands-Indië op basis van de Grondwet van 1922 zelfstandig zou worden binnen het Rijksverband, dat het ledental en de bevoegdheden van de Volksraad zouden worden uitgebreid en dat de departementshoofden daar als ministers verantwoordelijk aan zouden worden. De twee andere moties waren al in augustus 1939 voorgesteld, maar de behandeling ervan was meermalen uitgesteld. Soetardjo had een (ook door Moelia en Thamrin ondertekende) motie ingediend die vroeg om bestudering van de mogelijkheid van spoedige invoering van een Indisch burgerschap. Zulk een burgerschap zou op gelijke voet voor Nederlanders en Indonesiërs moeten gelden en daardoor breken met de rechtsongelijkheid op basis van ras die ten grondslag lag aan het koloniale rechtsbestel. Tenslotte was er een motie van Thamrin, mede-ondertekend door Soetardjo en Soekawati, die vroeg om in wetten, ordonnanties en andere officiële stukken in plaats van de termen 'Nederlands-Indië', 'Inlander' en 'Inlands' voortaan de termen 'Indonesië', 'Indonesiër' en 'Indonesisch' te gebruiken.

In de Volksraad ontmoetten deze moties kritiek van een aantal Nederlandse leden. Zij betoogden onder meer dat uitvoering van de moties onder de heersende omstandigheden onmogelijk was, omdat dit wetgeving vereiste die zonder medewerking van het Nederlandse parlement niet tot stand kon komen. De voorstellers stelden daar tegenover, dat men zich nu niet op het formele staatsrecht maar op staatsnoodrecht moest baseren, op basis waarvan ook de Nederlandse regering in Londen wetgeving uitvaardigde zonder medewerking van het parlement.

Eind augustus deelde de woordvoerder van het gouvernement in de Volksraad mee, dat het gouvernement niet aan het debat over de moties van Wiwoho en Soetardjo wenste deel te nemen, al zou het wel zijn algemene houding tegenover de besproken onderwerpen uiteenzetten. Los van de vraag van de bevoegdheden krachtens staatsnoodrecht noemde het gouvernement het een eis van goede trouw tegenover het Nederlandse volk om niet buiten het Nederlandse parlement om principiële wijzigingen aan te brengen in de Nederlands-Indische staatsrechtelijke structuur. Zelfs voorbereiding van zulke wijzigingen, waarbij Volksraad en gouvernement hun mening zouden vastleggen, diende achterwege te blijven zolang de moederlandse organen uitgeschakeld waren. Het gouvernement geloofde overigens niet dat de kolonie op korte termijn rijp zou zijn voor de invoering van een volledig parlementair stelsel. Hoewel het gouvernement het nu niet de tijd vond om plannen voor staatkundige veranderingen vast te leggen, zag het wel nut in het verzamelen van gegevens en gedachten ten behoeve van de latere oordeelsvorming. Het was van plan daartoe een kleine commissie in te stellen. 
Wat de motie-Thamrin betreft, had het gouvernement ernstig bezwaar tegen vervanging van de gebiedsaanduiding 'Nederlands-Indië' door 'Indonesië'. Wel was het bereid te zijner tijd mee te werken aan het verwijderen van de termen 'Inlander' en 'Inlands' uit de wetgeving en zou het nu al voorschrijven dat die termen in ambtelijke mededelingen zoveel mogelijk zouden worden vervangen door hetzij 'Indonesiër' en 'Indonesisch' hetzij 'Inheemse' en 'Inheems'.

De voorstellers van de moties toonden zich diep gegriefd door deze verklaring van het gouvernement. Wiwoho deelde namens alle ondertekenaren mee, dat zij hun moties introkken omdat er een zo grote kloof bestond tussen hun standpunt en dat van het gouvernement dat een verdere gedachten wisseling nu geen zin had. Zij behielden zich overigens het recht voor, de voor hen brandende kwesties te allen tijde weer ter sprake te brengen.

In september 1940 stelde het gouvernement de aangekondigde commissie in, die een onderzoek zou moeten instellen naar de bij de verschillende groeperingen levende wensen en meningen over de staatkundige ontwikkeling van Nederlands-Indië. Ook zou zij moeten studeren op de eventuele instelling van een Indisch burgerschap en de vervanging van de termen 'Inlander' en 'Inlands' in de wetgeving door andere termen. De commissie bestond uit drie Nederlanders, drie Indonesiërs en een Chinees. Voorzitter was F.H. Visman, lid van de Raad van Indië; de Indonesische leden waren Moelia, Soejono en Soepomo, een docent aan de Rechtshogeschool.

In het najaar van 1940 leverde Thamrin in de Volksraad ongewoon scherpe kritiek op het koloniale beleid. Hij zei dat de Nederlanders het totalitaire systeem wel veroordeelden, maar er in de kolonie zelf gebruik van maakten. Indonesië werd volstrekt autocratisch bestuurd door mensen uit een ander land ten bate van dat andere land. De Nederlanders wilden hun macht niet met de Indonesiërs delen, omdat zij hun winsten uit de kolonie niet wilden prijsgeven. De woordvoerder van het gouvernement uitte zich eveneens ongewoon scherp. Hij verklaarde dat het gouvernement met alle beslistheid het recht van Nederlandse onderdanen ontkende om een gebiedsdeel uit het verband van het Koninkrijk los te scheuren. Daarom moest het elke discussie over onafhankelijkheid categorisch afwijzen. Hij voegde daaraan toe dat, wanneer de nationalisten op onafhankelijkheid uit waren, zij het door hen bepleite volwaardige parlement met een daaraan verantwoordelijke regering kennelijk bedoelden als een fase in de strijd, als een machtsoverheveling om tot het einddoel van de onafhankelijkheid te komen. Een gezonde democratische ontwikkeling zou dan in een machtsstrijd ontaarden. Het gouvernement, aldus de woordvoerder, zou zijn standpunt daarin weten te bepalen. 
Laatste confrontaties tussen de nationale beweging en het koloniale gezag

Op 6 januari 1941 doorzocht de politie het huis van Thamrin en werd hijzelf, die toen ziek te bed lag, onder huisarrest geplaatst. Vijf dagen later overleed hij, slechts 46 jaar oud. Tienduizenden namen deel aan zijn begrafenis, die daarmee uitgroeide tot de laatste nationalistische massademonstratie onder het koloniale bestuur. Het gouvernement wilde niet meedelen wat de reden voor het optreden tegen Thamrin geweest was; het duidde alleen vaag aan dat hij verdachte Japanse contacten onderhouden had. Tijdens zijn huisarrest waren ook Ratoelangie en E.F.E. Douwes Dekker gearresteerd. De eerste werd al gauw vrijgelaten, maar Douwes Dekker, die rapporten voor het Japanse consulaat bleek te hebben opgesteld, bleef gevangen. Het gouvernement interneerde hem samen met de in 1940 gearresteerde NSB'ers.

Door de dood van Soetomo en Thamrin bleef er maar één nationalistische leider over die onder de Indonesische bevolking algemene bekendheid en aanzien genoot: Soekarno. Gouverneur-generaal Tjarda liet hem in het voorjaar van 1941 weten, dat hij naar Java zou kunnen terugkeren mits hij in publicaties het gouvernement zou steunen, maar Soekarno weigerde hierop in te gaan. Overigens publiceerde hij tijdens zijn ballingschap in Benkoelen verschillende artikelen waarin hij zich tegen de As-mogendheden keerde.

$\mathrm{Na}$ de instelling van de commissie-Visman was de Gapi eerst niet bereid daaraan mee te werken omdat zij er alleen een afleidingsmanoeuvre in zag, maar later werd toch besloten een stuk voor die commissie op te stellen. In februari 1941 overhandigde Abikoesno haar namens de Gapi een memorandum over de staatkundige constructie van Indonesië. Als einddoel duidde het memorandum een zelfstandige staat aan met een uit twee kamers bestaand parlement en een gekozen staatshoofd; dit zelfstandige Indonesië zou dan samen met Nederland een statenbond vormen. Als stap naar het einddoel zou de kolonie binnen vijf jaar, desnoods met toepassing van staatsnoodrecht, moeten veranderen in een gebied met volledig zelfbestuur. Daarbij zou onder meer de Nederlandse gouverneur-generaal een plaatsvervanger naast zich moeten krijgen in de persoon van een Indonesische luitenant-gouverneurgeneraal.

Enige maanden later kreeg de Gapi steun van de islamitische federatie MIAI, die in beginsel instemde met de in het Gapi-memorandum voorgestelde staatkundige constructie, maar wilde dat het staatshoofd en tweederde van de ministers islamieten zouden zijn en dat er een speciaal ministerie voor islamitische zaken zou komen. Onder de vele aan de commissie-Visman overgelegde politieke stellingnames was ook een advies van de Vaderlandsche Club, dat onder meer verklaarde dat elke gedachte aan liquidatie van het Nederlandse gezag buiten debat behoorde te blijven als in wezen neerkomende op landverraad. 
Het rapport van de commissie-Visman verscheen overigens pas in december 1941, zodat het in de kolonie geen rol in de discussies meer heeft kunnen spelen. De meest opvallende constatering van de commissie was, dat zij geen wensen gehoord had die zich richtten op verbreking van de band met Nederland. Aan de andere kant meldde zij dat alle door haar gehoorde Indonesiërs, Chinezen en Arabieren over hun maatschappelijke achterstelling klaagden en volledige rechtsgelijkheid met de Europeanen wensten.

In de eerste helft van 1941 botsten de Indonesische nationalisten met het gouvernement over de kwestie van inheemse dienstplicht. Deze kwestie, die al tijdens de Eerste Wereldoorlog in de 'Indië Weerbaar'-campagne tot controverses geleid had, was na de bezetting van Nederland opnieuw in discussie gekomen, waarbij de standpunten weinig verschilden van die van een kwart eeuw daarvoor. Hoewel er aan Nederlandse kant weinig voor werd gevoeld de inheemse bevolking op grote schaal van militaire opleiding en uitrusting te voorzien, vond men inheemse dienstplicht wel aantrekkelijk om de strijdkrachten op een goedkopere manier te versterken dan door uitbreiding van het beroepsleger. Daarentegen zagen de meeste nationalisten de Nederlandse belangstelling voor inheemse dienstplicht in de eerste plaats als een mogelijkheid tot het verkrijgen van politieke concessies. In dat verband hadden leden van de Nationale Fractie voor de oorlog herhaaldelijk in de Volksraad voor de invoering van zulke dienstplicht gepleit, maar het gouvernement wilde er toen niet van weten. Nu echter legde het gouvernement in januari 1941 aan de Volksraad een plan voor dat voorzag in de opbouw van een inheemse militie die in de eerste fase 7.000 man zou tellen en na tien jaar een uiteindelijke sterkte van 33.000 man zou bereiken. Dit plan stuitte op aanzienlijk verzet in de Indonesische pers. De in de Gapi samenwerkende organisaties verklaarden dat zij de invoering van inheemse dienstplicht afwezen, tenzij die zou worden ingesteld door een volwaardige volksvertegenwoordiging. Bij de behandeling van de dienstplicht-ordonnantie in de Volksraad in juli bleken de meeste Indonesische leden die wel te steunen. De Raad nam haar dan ook met ruime meerderheid aan; alleen de acht met de Gapi verbonden leden stemden tegen of namen niet aan de stemming deel. Tot ergernis van het gouvernement stuurden de Gapi en de MIAI daarna een telegram aan de koningin in Londen om de inwerkingtreding van de ordonnantie tegen te houden. De koningin bekrachtigde de ordonnantie in september. Nog in diezelfde maand werden op Java zesduizend inheemse dienstplichtigen opgeroepen, waarvoor overigens maar drieduizend geweren beschikbaar waren.

Hoewel het gouvernement zich in het najaar van 1940 tegenover de meeste Indonesische politieke wensen onbuigzaam had opgesteld, bleven sommige nationalisten hopen dat de regering in Londen daar meer open voor zou staan. Zij koesterden daarom verwachtingen van het bezoek dat minister Welter in april 1941 aan de kolonie bracht. Tot hun teleurstelling ging hij contacten met 
de Gapi uit de weg en verklaarde ook hij dat er pas sprake zou kunnen zijn van staatsrechtelijke hervormingen wanneer de oorlog afgelopen was en het Nederlandse staatsbestel weer normaal functioneerde.

Op 10 mei 1941 sprak koningin Wilhelmina in Londen een radiorede uit waarin zij ook een zin wijdde aan 'de aanpassing van de structuur der overzeese gebiedsdelen en de bepaling van hun plaats in het Koninkrijk overeenkomstig de gewijzigde omstandigheden'. Zij zei dat zij van plan was ruime gelegenheid te scheppen om wensen en opvattingen daarover te harer kennis te brengen en dat zij bereid zou zijn die aandachtig te overwegen. Een maand later deelde gouverneur-generaal Tjarda in de Volksraad mee, dat de regering daartoe na de bevrijding van het moederland een conferentie wilde bijeenroepen van vooraanstaande personen uit de verschillende delen van het Koninkrijk.

Ook voor die Indonesiërs die prijs stelden op behoud van een band met Nederland vormden deze toezeggingen een teleurstelling. Soetardjo zei in de Volksraad, dat de in uitzicht gestelde rijksconferentie de Indonesische beweging niet bevredigde. Hij spoorde het gouvernement aan niet te wachten totdat het te laat zou zijn. Men moest met spoed maatregelen nemen ter voorbereiding van staatkundige hervormingen, in de eerste plaats om de Indonesiërs op te heffen uit hun positie van overheerst volk en van tweederangsburgers. Dat zou ook bijdragen tot hun bereidheid om zich in te zetten voor de verdediging van het land. Een innerlijk verdeeld Indonesië zou onherroepelijk ten prooi vallen aan het agressieve buitenland. In dezelfde zitting spraken radicale nationalisten zich weer uit voor zelfbeschikking en onafhankelijkheid.

De woordvoerder van het gouvernement wees spoedige staatkundige hervormingen opnieuw van de hand. Aan het adres van de nationalisten uitte hij dreigende taal. Hun acties, zoals de campagne voor een parlement en het verzet tegen inheemse dienstplicht, konden een situatie scheppen die het gezag tot een straffere houding zou noodzaken. Het gouvernement respecteerde het nationalisme voorzover dit er op gericht was het gebied uit een status van ondergeschiktheid tot grotere zelfstandigheid te leiden. Twee zaken dienden echter buiten discussie te staan: de handhaving van het Koninkrijk der Nederlanden als een onverbrekelijk staatsverband en het erfelijk recht van koningin Wilhelmina en haar nakomelingen op de kroon van dat staatsverband. Het gouvernement, aldus de woordvoerder, zou deze essentiële zaken met alle middelen - ook de scherpste - beschermen tegenover ieder die deze zou willen aantasten.

Kritiek op de starre opstelling van het gouvernement verscheen medio 1941 zelfs in het conservatieve deel van de Nederlands-Indische pers. De voorzitter van de Volksraad, Jonkman, probeerde op eigen gezag de strekking van de toezeggingen van de regering te verruimen. In een toespraak op 31 augustus ter gelegenheid van de verjaardag van de koningin zei hij dat uit haar woor- 
den volgde, dat Indonesië en Nederland binnen het rijk gelijkwaardig zouden worden en dat de Indonesiërs en de Nederlanders gelijke rechten zouden krijgen. Het hinderde gouverneur-generaal Tjarda dat Jonkman de indruk wekte hiermee een officiële uitleg te geven. Zelf verklaarde hij bij dezelfde gelegenheid, dat de plaats van het moederland in het rijksverband de overzeese gebiedsdelen verplichtte tot beteugeling van hun vernieuwingsdrang.

Intussen hadden Churchill en Roosevelt op 15 augustus 1941 het Atlantisch Handvest wereldkundig gemaakt dat een reeks gemeenschappelijke beginselen bevatte. Eén daarvan was de eerbiediging van het recht van alle volkeren om de regeringsvorm te kiezen waaronder zij wilden leven. Een week later dienden Soetardjo en zevenentwintig andere Indonesische leden van de Volksraad een schriftelijke vraag in, waarin zij aandrongen op een spoedige en duidelijke uiteenzetting of de Nederlandse regering de Brits-Amerikaanse verklaring aanvaardde en wat daarvan de consequenties waren voor de Indonesische bevolking. Het gouvernement antwoordde in november, dat de regering het Atlantisch Handvest inderdaad onderschreef, dat dit Handvest richtlijnen aangaf voor de internationale verhoudingen en zich dus niet direct inliet met de interne verhoudingen van rijken wier bestaan zich in de geschiedenis had bevestigd, dat de regering overigens de in het Handvest vervatte beginselen al lang binnen het Koninkrijksverband toepaste voorzover die daarvoor in aanmerking kwamen, en dat zij daarom in haar instemming met dat Handvest geen aanleiding zag tot heroverweging van haar beleid ten aanzien van de onder Nederlands bestuur staande inheemse volkeren van Nederlands-Indië.

De steeds scherpere tegenstelling tussen het gouvernement en de nationale beweging leidde ertoe, dat de gelederen zich binnen die beweging steeds meer sloten. Dat bleek onder meer in augustus 1941 toen vrijwel alle Indonesische leden van de Volksraad de vraag over het Atlantisch Handvest ondertekenden. Het bleek opnieuw toen in september 1941 in Jogjakarta een tweede Indonesisch Volkscongres bijeenkwam, als vervolg op het congres dat in december 1939 had plaatsgevonden. Niet alleen waren alle in de Gapi verenigde organisaties hier vertegenwoordigd, maar ook alle groeperingen die in de islamitische federatie MIAI samenwerkten. Bovendien nam nu ook de PPBB (Soetardjo's bond van inheemse bestuursambtenaren) er aan deel, naast de federatie van vakbonden van inheems overheidspersoneel. Nog nooit was de eenheid binnen de nationale beweging zo groot geweest. Het congres besloot tot de oprichting van een Madjelis Rakjat Indonesia (MRI, Raad van het Indonesische Volk). Deze Raad zou optreden als vertegenwoordigend lichaam van het Indonesische volk en onder meer grote vergaderingen beleggen waarop dit volk besluiten zou kunnen nemen over alle zaken die zijn belangen raakten. Het congres plaatste de MRI aldus als voorstadium voor een volwaardig parlement tegenover de door Nederland in het leven geroepen Volksraad. 
Sinds mei 1940 had noch het Nederlands-Indisch gouvernement noch de regering in Londen daadwerkelijk tegemoet willen komen aan Indonesische wensen tot verandering van het koloniale bestel. Iedere tegemoetkoming zagen zij als een gevaarlijke concessie. Daardoor was er tussen de koloniale overheersers en de overheersten geen toenadering maar een ongekende verwijdering ontstaan. De oprichting van de MRI bezegelde de breuk tussen de nationale beweging en het Nederlandse gezag. Het gouvernement reageerde met een radicale maatregel: op 15 oktober 1941 kondigde het een totaal verbod op politieke bijeenkomsten af.

\section{Nederland in oorlog met Japan}

Omdat Japan voor zijn grondstoffenvoorziening in hoge mate van invoer afhankelijk was, kwam het in een dwangpositie door het in juli 1941 ingestelde Amerikaanse, Britse en Nederlandse handelsembargo. Het moest in ieder geval een uitweg vinden voordat zijn olievoorraden opraakten. Het kon die uitweg zoeken in een politiek akkoord teneinde opheffing van het embargo te verkrijgen, maar daartoe zou het zijn expansionistische ambities grotendeels moeten prijsgeven. Het kon de uitweg ook zoeken in het voeren van oorlog teneinde zich met geweld toegang tot de grondstoffen van Zuidoost-Azië te verschaffen. Wat Indonesië betreft, leken verschillende Japanse acties al uit te gaan van de tweede mogelijkheid. Japanse radio-uitzendingen in het Maleis verkondigden niet alleen de leuze 'Azië voor de Aziaten', maar voorspelden ook dat Japan een eind zou maken aan het Nederlandse koloniale bewind. Verder keerden tussen augustus en november een zesduizend in Indonesië wonende Japanners met Japanse schepen naar Japan terug.

Met instemming van gouverneur-generaal Tjarda besloot de Nederlandse regering dat, wanneer er oorlog zou uitbreken tussen Japan en het Britse Rijk en/of de Verenigde Staten, Nederland meteen aan Japan de oorlog zou verklaren. In het kader van de bondgenootschappelijke samenwerking stelde de Nederlandse marine eind november enige onderzeeboten en verkenningsvliegtuigen ter beschikking van het Britse opperbevel in Singapore. Begin december kwamen een Brits slagschip en een Britse slagkruiser de daar gestationeerde Britse vloot versterken.

Terwijl Japan nog in onderhandeling met de Verenigde Staten was over opheffing van het handelsembargo, opende het de oorlog met een verrassingsaanval op de marinebasis Pearl Harbor. Bij die aanval, op zondag 7 december plaatselijke tijd, schakelde het een groot deel van de Amerikaanse Pacific-vloot uit, waaronder vijf van haar acht slagschepen. Tezelfdertijd gingen Japanse troepen aan land op het schiereiland Malakka. Twee dagen na de overval op Pearl Harbor brachten Japanse vliegtuigen het Britse slagschip en de Britse 
slagkruiser tot zinken toen die de invasievloot bij Malakka wilden bestrijden. Op dezelfde dag gingen Japanse troepen aan land op de Filippijnen. Tot verbazing van veel Amerikanen, Britten en Nederlanders bleken Japanners wel degelijk vliegtuigen te kunnen besturen en geschut te kunnen richten. Hun jachtvliegtuigen en hun torpedo's waren bovendien beter dan die van de geallieerden. Sinds de eerste dagen van de oorlog bezat Japan zowel ter zee als in de lucht een volstrekt overwicht. Al spoedig beschikte het zowel op Malakka als op de Filippijnen over vliegvelden van waaraf het ook Indonesië kon bestrijken.

Op het tijdstip van de aanval op Pearl Harbor was het in Indonesië (gelegen ten westen van de datumlijn) maandag 8 december. Het gouvernement nam die dag een aantal stappen die al waren voorbereid. Tjarda deelde in een radiotoespraak mee dat Nederland de wapens opnam tegen Japan nu dit land onverhoeds Amerikaanse en Britse gebieden had aangevallen terwijl de Japanse veroveringslust zich zeker ook op Nederlands-Indië richtte. Van de dienstplichtige Nederlanders werden er vijfentwintigduizend gemobiliseerd om het KNIL te versterken. Ter verdediging van Malakka, Singapore en Brits-Borneo kreeg het Britse opperbevel de beschikking over nog meer Nederlandse marineschepen en over het grootste deel van de luchtmacht van het KNIL. Alle Nederlands-Indische koopvaardijschepen kwamen onder bevel van de Nederlandse marine te staan. Verder gaf het gouvernement opdracht alle nog niet gerepatrieerde Japanners te interneren. Evenals het geval was geweest bij de internering van de Duitsers in 1940 ging de uitvoering van deze opdracht gepaard met fouten en onnodige grofheden. Er werden ongeveer tweeduizend personen opgepakt, maar velen van hen waren geen echte Japanners maar Taiwanezen; verder waren er Chinezen en Indonesiërs bij die voor Japanners gewerkt hadden en Chinese en Indonesische vrouwen die met Japanners getrouwd waren.

Het gouvernement liet ook een aantal Indonesiërs arresteren die in nauw contact met Japanners hadden gestaan en sloot het persbureau Antara van de in de Gapi samenwerkende nationalistische organisaties. Voor de nationale beweging betekende het uitbreken van de Pacific-oorlog de bevestiging van een voorspelling die in die kring al ruim tien jaar gemeengoed was. Overigens waren de meeste leiders van die beweging niet pro-Japans gezind; de Gerindo was zelfs uitgesproken anti-Japans. Veel ontwikkelde Indonesiërs waren ervan op de hoogte dat Japan de bevolking van de geannexeerde gebieden Korea en Taiwan hardvochtig onderdrukte en dat het Japanse leger in China bijzonder wreed optrad. De eenvoudige Indonesiërs wisten hier zelden van; bij hen genoten de Japanners in het algemeen een veel betere reputatie dan de Chinezen.

Na het uitbreken van de Pacific-oorlog keerde Hatta zich in krantenartikelen tegen de misvatting dat het er niet toe deed of Nederlanders dan wel 
Japanners de baas in Indonesië waren en riep hij op tot bestrijding van het Japanse imperialisme. Van de kant van de Gapi en de MRI verscheen een manifest dat enerzijds de Indonesiërs opriep volledig mee te werken met het gouvernement bij het weerstaan van de buitenlandse aanval en anderzijds het gouvernement aanspoorde om samen met de Indonesische volksbeweging een nieuwe democratische orde op te bouwen. Tjarda bleef van mening dat politieke concessies aan de nationale beweging uit den boze waren, maar liet wel aan de Gapi en de MRI weten dat hij bereid was hen te betrekken bij overleg over verhoging van de oorlogsinspanning. Een in januari 1942 gevoerd gesprek tussen vertegenwoordigers van het gouvernement en van deze organisaties leidde tot niets wegens de onverenigbare uitgangspunten.

Overigens had dit manifest desastreuze gevolgen voor de zo kort daarvoor bereikte eenheid binnen de nationale beweging. Noch Abikoesno noch de bestuursraad van de MRI was namelijk in de opstelling ervan gekend. Vooral bij de Sarekat Islam bestond bezwaar tegen de in het manifest vervatte oproep tot medewerking met het gouvernement. Een en ander leidde ertoe dat de Sarekat Islam uit de Gapi trad en dat de MIAI zich terugtrok uit de MRI.

Bij het uitbreken van de oorlog was Van Mook formeel geen directeur economische zaken meer, maar minister van koloniën. In oktober was Welter namelijk afgetreden (om redenen die geen verband hielden met het koloniaal beleid) en Tjarda had toen Van Mook als diens opvolger aanbevolen. Wegens zijn Stuw-verleden stuitte dit eerst op bezwaren bij de minister-president in Londen, P.S. Gerbrandy, een partijgenoot en geestverwant van Colijn. Pas nadat Van Mook uitdrukkelijk verklaard had achter de beleidslijn te staan dat de staatkundige toekomst van Nederlands-Indië eerst na de oorlog aan de orde zou komen, werd hij tot minister benoemd. Op 8 december was hij echter nog niet naar Londen vertrokken. In de door de oorlog geschapen nieuwe situatie stelde Tjarda voor om Van Mook als zijn plaatsvervanger aan te stellen. De regering stemde hiermee in, ontsloeg Van Mook uit zijn ministersambt en benoemde hem per 1 januari 1942 tot luitenant-gouverneur-generaal, terwijl Gerbrandy zelf het ministerie van koloniën onder zijn hoede nam. Van Mook vertrok begin januari naar Washington om daar te pleiten voor ruimere en snellere hulp voor de verdediging van Indonesië.

\section{Verwijdering van niet-Indonesische geïnterneerden uit Nederlands-Indië}

$\mathrm{Na}$ het uitbreken van de oorlog met Japan besloot het gouvernement de geïnterneerde Duitsers, Japanners en onbetrouwbaar geachte Nederlanders uit Nederlands-Indië te verwijderen om te voorkomen dat ze in handen van de vijand zouden vallen. Bijna honderdvijftig Nederlanders die van landverraderlijke gezindheid werden verdacht, onder wie Douwes Dekker, werden 
in januari 1942 naar Suriname overgebracht. Dit gebeurde met een koopvaardijschip waarvan het dek tot een soort kooi was gemaakt. De Nederlandse marine droeg de kapitein op om in geval van een vijandelijke aanval het schip samen met de gevangenen tot zinken te brengen en alleen de bemanning en de bewaking gelegenheid te geven zich te redden. Er kwam geen aanval en de gevangenen bereikten veilig Suriname, waar ze de oorlogsjaren in gevangenschap doorbrachten onder een kampcommandant die hen zeer vijandig behandelde.

Het gouvernement liet de geïnterneerde echte en niet-echte Japanners, waaronder ruim vijfhonderd vrouwen en kinderen, in twee koopvaardijschepen naar Australië overbrengen. Tijdens de reis werden ze niet gelucht en kregen ze weinig te drinken; enkelen stierven tijdens het transport. In Australië werden ze weer in een interneringskamp ondergebracht.

Omdat de geïnterneerde Duitsers in Noord-Sumatra gevangen zaten, werd besloten hen naar India over te brengen. Nadat eind december en begin januari de eerste twee transporten vertrokken waren, waaronder zich degenen bevonden die men het meest gevaarlijk achtte, bleef er een restgroep over van 473 man. Daartoe behoorden alle bejaarde geïnterneerden, een groot aantal IndoEuropeanen, bijna tachtig zeelieden van Duitse schepen die op 10 mei 1940 in Indonesische havens hadden gelegen, tientallen zendelingen en priesters, enige kunstenaars en geleerden, verscheidene joden aan wie het nazi-regime hun staatsburgerschap ontnomen had, een aantal andere anti-nazi gezinden en tenslotte acht verpleegden uit een krankzinnigengesticht. Midden januari bracht men hen aan boord van het KPM-schip de 'Van Imhoff', waarvan men de ruimen en een deel van het dek met behulp van prikkeldraad in kooien verdeeld had. De kapitein wees de marineleiding er op dat het schip te weinig reddingsboten had voor zoveel opvarenden. Hij kreeg alleen ten antwoord dat hij alle Duitsers onmiddellijk aan boord moest nemen.

De 'Van Imhoff' vertrok op 18 januari, maar werd de volgende dag in de buurt van het eiland Nias door een Japans vliegtuig aangevallen. Het schip kreeg een lek en de kapitein liet noodseinen uitzenden. Een uur later, toen het schip slagzij begon te maken, gingen de bemanning en de bewaking aan boord van vijf sloepen. De opgesloten Duitsers slaagden er in door de prikkeldraadversperring heen te breken en zagen de sloepen zonder hen wegvaren. Ongeveer honderdzeventig probeerden zich te redden met de twee overgebleven boten en de reddingsvlotten. Vijf uur later zonk de 'Van Imhoff' met nog ruim driehonderd Duitsers aan boord. De Nederlandse marinestaf, die niet wist wat er sinds de ontvangst van de noodseinen gebeurd was, zond de volgende dag een ander KPM-schip uit voor een reddingsactie. De kapitein daarvan kreeg opdracht eerst de bemanning en de bewaking te redden en daarna, op aanwijzing van de militaire commandant, 'betrouwbare elementen' onder de Duitsers; de overige Duitsers moest hij beletten aan land te komen. In het 
gebied van de ramp trof hij in de twee boten en op reddingsvlotten ongeveer negentig Duitsers aan, maar hij liet hen aan hun lot over omdat hij niet wist wie van hen betrouwbaar was. Ruim tweederde van deze schipbreukelingen wist Nias te bereiken, waar het Nederlandse bestuur hen opnieuw gevangen zette; de overigen kwamen om. De bemanning en de bewaking van de 'Van Imhoff' waren intussen op een ander eiland aangeland; zij werden naar Sumatra overgebracht en kregen bevel het gebeurde geheim te houden.

Naast de niet-Indonesische geïnterneerden, die het gouvernement buiten bereik van de vijand wilde houden, bevonden zich in Nederlands-Indië nog honderden Indonesische geïnterneerden. Dit waren enerzijds personen die het gouvernement al voor de oorlog met Japan uit de samenleving had verwijderd (meestal naar Boven-Digoel), anderzijds personen die het na het uitbreken van die oorlog had laten oppakken. Onder de eerste groep was er één die zelf te kennen gaf niet in Japanse handen te willen vallen. Dit was Soekarno, die vergelding vreesde voor zijn anti-Japanse uitlatingen. Toen de Japanse troepen in februari naderbij kwamen, vroeg hij per telegram aan de gouverneur-generaal hem naar Australië te laten afvoeren. Tjarda besloot echter Soekarno op Sumatra te laten blijven. Hij handhaafde ook de internering van Hatta en Sjahrir, die hij kort daarvoor van Banda had laten overbrengen naar Soekaboemi in West-Java.

\section{Verloop van de oorlog tot maart 1942}

De militaire situatie in Zuidoost-Azië werd van de eerste oorlogsdagen af steeds ongunstiger voor Nederland en zijn bondgenoten. Op Malakka rukte het Japanse leger langzaam maar onweerstaanbaar op in de richting van Singapore. Midden december gingen Japanse troepen ook in Brits-Borneo aan land. De Britse kolonie Hongkong gaf zich op 25 december over. Het Japanse luchtoverwicht dwong de Amerikaanse luchtmacht en marine de Filippijnen te verlaten. Japan kreeg belangrijke delen van de Filippijnen in handen en bezette op 2 januari Manila; ten westen daarvan verschansten Amerikaanse en Filippijnse troepen onder generaal MacArthur zich op het schiereiland Bataan. Nederlandse vliegtuigen en onderzeeboten schakelden verscheidene Japanse schepen en vliegtuigen uit, maar leden zelf zware verliezen.

Om de operaties van de Amerikaanse, Britse, Nederlandse en Australische strijdkrachten in Zuidoost-Azië beter te coördineren besloot men daar een gemeenschappelijk opperbevel in te stellen, het American-British-DutchAustralian Command. Het zou zijn aanwijzingen krijgen van het hoogste geallieerde opperbevel, de Combined Chiefs of Staff in Washington, die rechtstreeks onder Churchill en Roosevelt stonden. ABDA Command werd gevestigd in Lembang bij Bandoeng en trad op 15 januari in werking onder leiding 
van generaal Wavell, de Britse opperbevelhebber in India. De Nederlandse legercommandant, luitenant-generaal $\mathrm{H}$. ter Poorten, en de commandant zeemacht, vice-admiraal C.E.L. Helfrich, werden nu aan hem ondergeschikt. Ter Poorten was pas eind oktober 1941 legercommandant geworden, nadat zijn voorganger was omgekomen bij een vliegongeluk. Hij had aan de wieg gestaan van het luchtwapen van het KNIL en was zich ervan bewust dat de mogelijkheden om de Japanse opmars te stuiten ernstig beperkt werden door het Japanse luchtoverwicht. Helfrich tilde hier minder zwaar aan en pleitte bij zijn Britse en Amerikaanse collega's voor een meer offensieve inzet van de zeestrijdkrachten. Op zijn aandrang werden de belangrijkste bovenwaterschepen van de vier marines bijeengebracht in een gezamenlijk eskader onder commando van de Nederlandse schout-bij-nacht Karel Doorman. Bovendien kreeg hijzelf in februari het bevel over alle ABDA-zeestrijdkrachten.

Toen de geallieerden besloten tot de instelling van ABDA Command, meenden zij nog de Japanners uit Java te kunnen weren. In verband daarmee werden ook Britse, Australische en Amerikaanse strijdkrachten naar Java overgebracht en werd een deel van de uit de Filippijnen teruggetrokken Amerikaanse vloot in Soerabaja gestationeerd. De vooruitzichten voor het behoud van Java gingen echter snel achteruit. Al voordat ABDA in werking trad landden Japanse strijdkrachten ook op Nederlands-Indisch grondgebied, namelijk op 11 januari, zowel bij Menado in Noord-Celebes als op het eiland Tarakan, een aardoliecentrum voor de kust van Oost-Borneo. Nadat de Japanners bij de verovering van het vliegveld van Menado zware verliezen hadden geleden, doodden zij daar alle overlevende verdedigers; het KNIL trok zich in het binnenland terug. Op Tarakan moest het KNIL na ruim een dag capituleren, maar intussen waren al voor de Japanse landing alle boorputten en olietanks vernield. Het Japanse leger dreigde daarop met scherpe represailles als ook de olie-installaties van Balikpapan vernield zouden worden, het grootste oliecentrum in Oost-Borneo. Voor de Nederlanders was dit dreigement aanleiding om deze vernielingen zo snel mogelijk uit te voeren. Op 24 januari veroverde het Japanse leger Balikpapan. Het voerde zijn dreigement uit door een openbare executie van bijna tachtig Europese burgers en militairen. Het derde voor Japan belangrijke aardoliegebied was dat van Djambi en Palembang op Sumatra. Om vernielingen vóór te zijn voerden de Japanners daar op 14 februari een aanval met parachutisten uit; zij kregen een deel van de olietanks en raffinaderijen ongeschonden in handen.

Intussen had Japan ook andere delen van de buitengewesten bezet, waaronder Ambon en Makassar. De snelle Japanse opmars in de Indonesische buitengewesten bracht de geallieerden ernstig in het nauw, maar nog veel ernstiger was het dat Singapore op 15 februari moest capituleren. Singapore gold als een onneembare vesting en was door veel Britten en Nederlanders gezien als de hoeksteen van de verdediging van Zuidoost-Azië. Enkele dagen 
na de val van Singapore nestelde Japan zich bovendien op Bali en Timor. Java werd nu zo bedreigd dat het voor de geallieerden niet meer verantwoord was hun gemeenschappelijk hoofdkwartier daar te handhaven. ABDA Command werd op 25 februari opgeheven; generaal Wavell keerde naar India terug. Ter Poorten kreeg het bevel over alle geallieerde landstrijdkrachten op Java, Helfrich over alle geallieerde zeestrijdkrachten in dit gebied.

Van het geallieerde eskader onder schout-bij-nacht Doorman was in de afgelopen weken veel gevergd. Het was zowel in de richting van Zuid-Celebes als van Zuid-Sumatra gedirigeerd en was zwaar bestookt door Japanse vliegtuigen, maar had zelf de Japanse strijdkrachten geen schade kunnen toebrengen. Dit laatste was vooral te wijten aan het ontbreken van doeltreffende luchtverdediging en luchtverkenning. Het was de vraag of het eskader nog moest worden ingezet tegen de nu te verwachten invasie op Java. Uit zuiver militair oogpunt leek het verstandiger deze oorlogsschepen uit het gebied terug te trekken om ze te behouden voor latere fasen van de oorlog. Uit politiek oogpunt was het voor Helfrich en Tjarda ondenkbaar dat de Nederlandse marine de Nederland-Indische wateren zou verlaten zonder slag te hebben geleverd voor het behoud van Java.

Op 26 februari zag een Nederlands marinevliegtuig op de Javazee ten westen van Makassar een Japans konvooi van tientallen transportschepen dat onder escorte van oorlogsschepen in de richting van Java voer. Helfrich droeg Doorman in Soerabaja op met zijn eskader dit convooi te vernietigen. Het eskader kon het konvooi niet vinden, maar raakte in de middag van de volgende dag slaags met het Japanse marine-escorte. Er volgde een langdurige zeeslag, waarbij Doorman de Japanse oorlogsschepen bleef opzoeken en aanvallen tot hij tegen middernacht zelf met zijn schip ten onder ging. Van het geallieerde eskader gingen tijdens de slag en de twee daarop volgende dagen in totaal vijf kruisers en vier torpedobootjagers verloren. Daarentegen werd aan Japanse kant alleen één torpedobootjager tijdelijk uitgeschakeld. Verder leidde het optreden van het eskader tot één dag uitstel van de Japanse landingen op de Javaanse kust.

\section{De Nederlandse capitulatie}

Na de val van Singapore ging het gouvernement ervan uit dat Japan zich spoedig ook van Java meester zou willen maken. Wegens de kwetsbare ligging van Batavia besloot men in de eerste plaats de belangrijkste delen van het centrale bestuur naar Bandoeng te verplaatsen; ook gouverneur-generaal Tjarda ging daarheen. Veel Nederlanders dachten dat men de tussen bergen gelegen hoogvlakte van Bandoeng nog maandenlang tegen de Japanners zou kunnen verdedigen. Zowel het gouvernement als de regering in Londen besefte echter 
dat men hoe dan ook rekening moest houden met een Japanse verovering van heel Java. Men besloot dat de gouverneur-generaal en de Nederlandse ambtenaren dan op hun post zouden blijven om duidelijk te maken dat Nederland Nederlands-Indië niet in de steek liet. Slechts enkele tientallen sleutelfiguren en specialisten zouden, zonder hun gezinnen, geëvacueerd moeten worden om te helpen bij de voortzetting van de oorlog en de behartiging van de belangen van het rijksdeel. Verder zou men een geheime organisatie moeten opbouwen die de regering zou kunnen inlichten over de situatie in het door Japan bezette gebied. Tenslotte verwachtte de regering van het KNIL dat het onder een Japanse bezetting de strijd zoveel mogelijk zou voortzetten in de vorm van guerrilla-oorlogvoering.

Met het opbouwen van een geheime inlichtingenorganisatie belastte zich Van der Plas, lid van de Raad van Indië, samen met het hoofd van de dienst Oost-Aziatische zaken, A.H.J. Lovink. Er kwam weinig van terecht, onder meer omdat men er veel te laat mee begon. Eén van hun contactpersonen was Amir Sjarifoeddin, de vroegere leider van de Gerindo. Deze had zich in 1940 uit de politiek teruggetrokken, was christen geworden en was bij het departement van economische zaken in dienst getreden. Van der Plas zorgde ervoor dat Amir een bedrag van vijfentwintigduizend gulden kreeg voor het opzetten van een illegale organisatie.

Over de keuze van de te evacueren deskundigen pleegde Tjarda overleg met Van Mook, die op 20 februari terugkeerde uit de Verenigde Staten. Hij had daar bij leidende figuren (tot en met president Roosevelt) aangedrongen op zo krachtig mogelijke steun voor de verdediging van Nederlands-Indië. Van Mook, wiens terugreis bijna twee weken geduurd had, was niet op de hoogte van de laatste ontwikkelingen en dacht dat het nog mogelijk was Bali te heroveren en Java te behouden.

In feite had het hoogste geallieerde opperbevel Java toen al opgegeven en besloten daar geen troepen meer heen te sturen. Sinds begin februari bestookte de Japanse luchtmacht er havens en vliegvelden. Zij maakte de haveninstallaties van Soerabaja en Tandjong Priok grotendeels onbruikbaar en bracht ook schepen tot zinken (waaronder de oude 'De Zeven Provinciën'). Op de vliegvelden vernielde zij meer dan de helft van de Nederlandse en bijna de helft van de Amerikaanse bommenwerpers, terwijl er ook vele in de lucht werden neergeschoten; eind februari besloten de Amerikanen de resterende Amerikaanse vliegtuigen naar Australië terug te trekken. Na de slag op de Javazee weken de nog intact gebleven geallieerde oorlogsschepen uit naar Australië en Ceylon. Helfrich legde het commando over de geallieerde zeestrijdkrachten neer en vertrok op last van Tjarda naar Ceylon om daar een nieuwe hoofdkwartier voor de Nederlandse marine in te richten. Wat de landstrijdkrachten betreft beschikte men op Java over slechts drieentwintigduizend man aan gevechtstroepen (waaronder een Australisch contingent 
van ruim tweeduizend man, aangevuld met ruim vijfhonderd Britten en Amerikanen), zodat men grote delen van het eiland onverdedigd moest laten. Bovendien had de strijd op Malakka, op de Filippijnen en in de Indonesische buitengewesten laten zien dat de landmacht weinig kon uitrichten als gevolg van het Japanse luchtoverwicht. In de buitengewesten was verder gebleken dat veel inheemse KNIL-soldaten zich al spoedig aan de strijd onttrokken en dat de inheemse bevolking de zegevierende Japanners soms hartelijk verwelkomde. In dat licht leek langdurige guerrilla-oorlogvoering nauwelijks denkbaar, want dat zou alleen mogelijk zijn als de plaatselijke bevolking bereid zou zijn de guerrillastrijders te steunen en daarvoor risico's te lopen.

Binnen de Japanse strijdkrachten was de verovering van Java opgedragen aan het Zestiende Leger onder luitenant-generaal Hitoshi Imamura. De invasiemacht telde ongeveer vijfenveertigduizend man, ondergebracht in twee konvooien waarvan het ene ten westen en het andere ten oosten van Borneo naar Java voer. Het oostelijke convooi werd op 26 februari door een Nederlands vliegtuig waargenomen, wat leidde tot de slag op de Javazee en tot één dag uitstel van de landingen. In de vroege uren van zondag 1 maart gingen Japanse troepen aan land op vier plaatsen aan de noordkust van Java, bij Merak en Bantam in het uiterste westen, bij Eretan (negentig kilometer ten noordoosten van Bandoeng) en bij Rembang (tussen Semarang en Soerabaja). Zij konden de weinige tegenstand die ze er ontmoetten gemakkelijk overwinnen. Nederlandse en Britse vliegtuigen vielen de konvooien en de ontschepingen herhaaldelijk aan, maar brachten geen zware verliezen toe.

Van de kant van Bantam begonnen de Japanners op te rukken naar Batavia en naar Buitenzorg, van de kant van Rembang zowel naar Soerabaja als naar Tjilatjap aan de zuidkust. Daarbij ondervond hun opmars meer vertraging door wegversperringen en vernielde bruggen dan door gevechten. Waar zij op krachtig verzet stuitten, riepen zij de hulp van de luchtmacht in om het verzet te breken.

De landing bij Eretan had in de eerste plaats ten doel een militair vliegveld in handen te krijgen, gelegen bij Kalidjati in de kustvlakte ten noorden van het bergplateau van Bandoeng. De afstand over de weg tussen de landingsplaats en dit vliegveld bedroeg negentig kilometer. Zondagochtend vertrokken duizend Japanse soldaten daarheen, van wie achthonderd per fiets en de anderen in vier vrachtauto's. Samen met enkele tanks bereikten zij om elf uur het vliegveld, dat na een korte strijd vrijwel ongeschonden in hun handen viel. De volgende dag stationeerde de Japanse luchtmacht er jagers en bommenwerpers. Alle pogingen die het KNIL tot en met dinsdag ondernam om het vliegveld te heroveren liepen spaak.

Ten behoeve van die pogingen werden ook strijdkrachten onttrokken aan de Nederlandse en geallieerde troepen die zich ten westen van het plateau van Bandoeng bevonden. De commandant van deze troepen, generaal 
W. Schilling, had een offensief willen openen tegen de bij Bantam gelande invasiemacht, maar moest daar nu van afzien. Vervolgens kreeg hij op woensdag opdracht zijn troepen in hun geheel naar het plateau van Bandoeng over te brengen, want de legertop had besloten Batavia en Buitenzorg prijs te geven teneinde Bandoeng zo lang mogelijk te kunnen verdedigen. De overbrenging van de troepen van generaal Schilling nam de hele donderdag en vrijdag in beslag, waardoor ze niet meer konden deelnemen aan de strijd.

De Japanse landingen op Java maakten het dringend nodig de door Tjarda en Van Mook uitgekozen deskundigen naar Australië te laten vertrekken. Verscheidene van de aangezochte personen hadden het voorstel tot evacuatie afgewezen omdat zij hun gezin niet in de steek wilden laten. Uiteindelijk vertrokken er ongeveer twintig, onder wie Van der Plas, Lovink, Soejono, Loekman Djajadiningrat en de KNIL-kapiteins S.H. Spoor en D.C. Buurman van Vreeden.

Tjarda en Ter Poorten wisten dat een totale Japanse overwinning op Java niet meer te vermijden was. De regering in Londen verbood een algehele capitulatie van Nederlands-Indië echter categorisch en gelastte Tjarda zijn functie van opperbevelhebber neer te leggen opdat hij niet zelf tot zulk een capitulatie gedwongen zou kunnen worden. Tjarda voldeed woensdag aan deze opdracht zonder overleg met Ter Poorten, op wie het opperbevel over de landstrijdkrachten nu overging. Ter Poorten verklaarde vervolgens per telegram aan alle commandanten van het KNIL dat, als hij ooit bevel tot capitulatie zou geven, zij ervan uit moesten gaan dat zulk een bevel onder dwang gegeven en daarom ongeldig was.

Nadat het KNIL zich uit Batavia had teruggetrokken, liet het gemeentebestuur donderdag aan het Japanse leger weten dat de stad niet verdedigd zou worden. De Japanse troepen trokken 's avonds Batavia binnen. Op diezelfde dag bezetten zij Buitenzorg. In Oost- en Midden-Java ontruimde het KNIL donderdag Soerabaja en vrijdag Tjilatjap.

Intussen had Van Mook er bij Tjarda op aangedrongen dat deze Java zou verlaten en hemzelf daar laten blijven, maar Tjarda stond er op zelf te blijven en Van Mook ter beschikking van de Nederlandse regering te stellen. Op vrijdagavond vertrok Van Mook naar Australië met één van de laatste vliegtuigen die nog konden wegkomen.

In Batavia kondigde het Japanse leger zaterdag zijn eerste verordeningen af. De Japanners namen de Nederlandse burgemeester en verscheidene andere bestuursfunctionarissen gevangen omdat ze weigerden trouw aan het Japanse leger te zweren.

De uit Kalidjati oprukkende Japanse troepen begonnen zaterdag Bandoeng te naderen. Tjarda wilde niet dat de burgerbevolking het slachtoffer van luchtbombardementen zou worden. Tegen de avond bood Ter Poorten de commandant van deze Japanse troepen de overgave aan van de Nederlandse 
strijdkrachten op het plateau van Bandoeng. De Japanse commandant liet het vuren staken en deelde mee dat de capitulatie de volgende dag nader zou worden geregeld.

Op zondag 8 maart deelde de Japanse legerleiding mee dat generaal Imamura in Kalidjati een gesprek wenste te hebben met zowel de gouverneurgeneraal als de legercommandant. Dezen vermoedden dat Imamura geen genoegen nam met een gedeeltelijke capitulatie. Tjarda weigerde eerst te gaan, maar zwichtte voor een Japans dreigement met een bombardement op Bandoeng. In Kalidjati eiste Imamura inderdaad algehele overgave. Tjarda zei dat hij geen opperbevelhebber meer was en daarom niet bevoegd was hierover te spreken. Uiteindelijk aanvaardde Ter Poorten de Japanse eis, maar hij wees er ook op dat hij donderdag bevel had gegeven geen rekening te houden met een eventueel door hem uit te geven opdracht om de wapens neer te leggen. Imamura antwoordde dat hij hem gelegenheid zou geven bekend te maken dat hij zijn bevel van donderdag introk.

Op maandag 9 maart maakte Ter Poorten via radio en pers bekend dat hij samen met de gouverneur-generaal gesproken had met de Japanse opperbevelhebber en dat hij zich genoodzaakt had gezien in te stemmen met onvoorwaardelijke capitulatie. Hij gaf daarom opdracht onmiddellijk de strijd te staken, de witte vlag te hijsen, alle troepen te ontwapenen en contact op te nemen met de dichtstbijzijnde Japanse commandant. Tenslotte deelde hij mee dat dit bevel ook gold voor de Nederlandse marine.

De Japanse soldaten trokken Bandoeng binnen. Ter Poorten werd krijgsgevangene. Tjarda kreeg voorlopig huisarrest. In Batavia werd het paleis van de gouverneur-generaal ingericht als ambtswoning voor Imamura.

\section{Aantekeningen bij hoofdstuk IV}

\section{Literatuuroverzicht}

De eerste gedetailleerde studie over de Indonesische nationale beweging verscheen in 1931, toen deze beweging nog volop in ontwikkeling was. Dit was De nationalistische beweging in Nederlandsch-Indië door J.Th. Petrus Blumberger (in 1987 herdrukt met een inleiding van H.A. Poeze). Voordien waren in Nederland wel enige polemische geschriften over het Indonesisch nationalisme verschenen, zowel van tegenstanders als van voorstanders. De belangrijkste uit de eerste categorie waren Het gist in Indië; Een analyse der hedendaagsche nationalistische beweging (1927) door M.W.F. Treub en Koloniale vraagstukken van heden en morgen (1928) door H. Colijn. De belangrijkste uit de tweede categorie waren Indonesie vrij (1928) door Mohammad Hatta en Indonesië klaagt aan! (1931) door Soekarno. Deze laatste twee publicaties bevatten de pleitredes die Hatta en Soekarno geschreven hadden toen zij wegens hun politieke activiteiten terechtstonden. Petrus Blumberger, een ambtenaar van het Nederlands-Indisch gouvernement en later van het Nederlandse departement van koloniën, schreef 
ook werken over de communistische beweging en de Indo-Europese beweging in Nederlands-Indië. Verder werden in Nederland voor de Tweede Wereldoorlog geen serieuze studies over het Indonesisch nationalisme gepubliceerd.

In Indonesië zelf publiceerde L.M. Sitorus in 1947 het eerste historische overzicht van de nationale beweging: Sedjarah pergerakan kebangsaan Indonesia (Geschiedenis van de Indonesische nationale beweging). Hierop volgden Sedjarah pergerakan rakjat Indonesia (Geschiedenis van de Indonesische volksbeweging, 1949) door A.K. Pringgodigdo en Om de vrijheid (1950) door D.M.G. Koch. In Nederland zelf publiceerde J.M. Pluvier in 1953 zijn Overzicht van de ontwikkeling der nationalistische beweging in Indonesie in de jaren 1930 tot 1942, dat een voortzetting vormde van het door Petrus Blumberger begonnen werk.

In de eerstvolgende jaren richtten Nederlandse historici zich, wat de vooroorlogse politieke ontwikkelingen in Indonesië betreft, in hoofdzaak op het Nederlandse beleid en de rol van Nederlandse politici. Voorbeelden hiervan zijn een boek van B.J. Brouwer uit 1958 over Idenburg en Colijn, een in 1961 door H. Baudet en I.J. Brugmans gepubliceerde artikelenbundel onder de titel Balans van beleid; Terugblik op de laatste halve eeuw van Nederlands-Indië, en een in 1964-1965 door S.L. van der Wal uitgegeven bronnenpublicatie over De Volksraad en de staatkundige ontwikkeling van NederlandsIndië. In dezelfde lijn passen het boek van J.C.H. Blom uit 1975 over de muiterij op 'De Zeven Provinciën', dat van P.J. Drooglever uit 1980 over de Vaderlandsche Club, dat van E.B. Locher-Scholten uit 1981 over de ethische politiek en dat van E. Henssen uit 1983 over Gerretson.

Daarentegen richtten verscheidene historici buiten Nederland zich vooral op de rol van de Indonesiërs zelf in de vooroorlogse ontwikkelingen binnen Indonesië. Al in 1952 publiceerde G.McTurnan Kahin Nationalism and revolution in Indonesia, waarvan de eerste honderd pagina's aan de vooroorlogse nationale beweging gewijd waren. In 1960 verscheen een studie van $\mathrm{R}$. Van Niel over de opkomst van de moderne Indonesische elite. In 1964 werd de ideologie van de nationale beweging door B. Dahm behandeld in zijn boek over Soekarno's strijd om de onafhankelijkheid. R. McVey publiceerde in 1965 een boek over de opkomst van het Indonesische communisme, A. Nagazumi in 1972 een overzicht van de eerste tien jaar van Boedi Oetomo, K. Tsuchiya in 1987 een studie over de opkomst van de Taman Siswa-beweging en T. Shiraishi in 1990 een meer algemene studie over de opkomst van de nationale beweging. S. Abeyasekere behandelde in publicaties van 1973 en 1976 de geschiedenis van de Indonesische nationale beweging tijdens de periode 1936-1941. Van J. Ingleson verschenen in 1975 en 1979 belangrijke studies over de Perhimpoenan Indonesia en over de nationalistische beweging in het tijdvak 1923-1934. Verder publiceerden auteurs als J.D. Legge, R. Mràzek, C.L.M. Penders en M. Rose biografieën van leidende figuren van die beweging, onder wie Hatta, Sjahrir en Soekarno.

In Indonesië zelf bestonden na 1950 de bijdragen tot de geschiedschrijving van de nationale beweging vooral uit memoires van personen die in die beweging een rol gespeeld hadden, zoals Abu Hanifah, Hatta, Iwa Kusuma Sumantri, Adam Malik, Mohammad Roem, Ali Sastroamidjojo en Achmad Subardjo. Een eerdere bijdrage was de in 1947-1948 door Tan Malaka geschreven autobiografie onder de titel Dari pendjara ke pendjara (Van gevangenis naar gevangenis). Verder verschenen er, naast de hierboven al genoemde werken van Sitorus en Pringgodigdo, nog andere algemene overzichten, zoals Sedjarah pergerakan nasional Indonesia (Geschiedenis van de 
Indonesische nationale beweging) door Susanto Tirtoprodjo (1962b), Sedjarah revolusi Indonesia (Geschiedenis van de Indonesische revolutie) door Iwa Kusuma Sumantri (1966-1969) en Sejarah pergerakan nasional (Geschiedenis van de nationale beweging) door Sartono Kartodirdjo (1989).

Intussen was men ook in Nederland meer aandacht gaan geven aan de geschiedenis van de Indonesische nationale beweging. Op basis van materiaal in Nederlandse overheidsarchieven verscheen in 1967 onder redactie van S.L. van der Wal een publicatie van interne documenten onder de titel De opkomst van de nationalistische beweging in Nederlands-Indie. Dit werk werd voortgezet door R.C. Kwantes in de vorm van een vierdelige bronnenpublicatie, getiteld De ontwikkeling van de nationalistische beweging in Nederlands-Indië (1978-1982). Deze publicaties bevatten zeer veel gegevens over de maatregelen van het Nederlands-Indische gouvernement tegenover die beweging en haar leiders. Een bijdrage van heel andere aard was een in 1976 door H.A. Poeze gepubliceerde beschrijving van het leven van Tan Malaka tot aan 1945, in feite na het werk van Pluvier de eerste studie waarin een Nederlandse historicus de Indonesische vrijheidsbeweging van binnenuit behandelde. Van de hand van A.P.E. Korver verscheen in 1982 een studie over de opkomst en bloei van de Sarekat Islam. In hetzelfde jaar begon H.A. Poeze met de uitgave van een nieuwe bronnenpublicatie, Politiekpolitioneele overzichten van Nederlandsch-Indië. Dit betrof maandelijkse geheime overzichten die het justitie-apparaat van Nederlands-Indië in de periode 1927-1941 had opgesteld ten behoeve van de hoogste functionarissen van het Nederlands-Indische gouvernement; de vier delen van deze bronnenpublicatie, telkens van inleidingen en overzichten voorzien, verschenen in 1982, 1983, 1988 en 1994.

Gebruik makend van het talrijke ter beschikking gekomen materiaal schreef L. de Jong een veelomvattend overzicht van de Indonesische nationale beweging, dat in 1984 in druk verscheen in de vorm van de hoofdstukken 6, 7 en 10 van deel 11a van zijn standaardwerk Het Koninkrijk der Nederlanden in de Tweede Wereldoorlog. Over de vroege fase van die beweging nam F. Tichelman tal van gegevens op in zijn boek van 1985 over de Indische Sociaal-Democratische Vereeniging. Een verdere bijdrage tot kennis van de nationale beweging werd geleverd door het in 1986 door H.A. Poeze gepubliceerde boek In het land van de overheerser - I. Indonesiërs in Nederland 1600-1950; de beweging dankte haar ontstaan immers ten dele aan Indonesiërs die in Nederland studeerden. Een andere bijdrage tot die kennis was de bloemlezing De roep om merdeka; Indonesische vrijheidlievende teksten uit de twintigste eeuw, verschenen in 1995 onder redactie van H.A. Poeze en $\mathrm{H}$. Schulte Nordholt.

Ook verder hebben Nederlandse auteurs zich herhaaldelijk met de Indonesische nationale beweging beziggehouden. Zo publiceerde H. van Miert in 1995 een studie over onder meer de Indonesische jeugdbeweging in de periode 1918-1930. H.W. van den Doel wijdde een hoofdstuk aan de nationalistische beweging in zijn in 1996 verschenen Het Rijk van Insulinde. Een boek van M. Maters uit 1998 over de behandeling van de pers in het vooroorlogse Nederlands-Indië is eveneens voor de geschiedenis van die beweging relevant. B. Hering publiceerde in 1997 een biografie van Thamrin en in 2002 een biografie van Soekarno (tot eind 1945). Ook verscheen er in 1999 en 2001 een tweedelige biografie van Soekarno door L.J. Giebels.

Het ontluiken van de Indonesische drang naar mondigheid

Over Abdul Rivai en het tijdschrift Bintang Hindia zie Poeze 1986. 
Boedi Oetomo en andere organisaties op etnische grondslag

Zie Petrus Blumberger 1931:19-54 en Nagazumi 1972. Over de theosofische beweging zie De Tollenaere 1996. Over E.F.E. Douwes Dekker zie Glissenaar 1999 en Van der Veur 2006. Over Tjipto Mangoenkoesoemo zie Shiraishi 1990:117-27. Over Soetomo zie Van der Veur 1987.

Het gebouw waarin de STOVIA gevestigd was in de eerste decennia van de twintigste eeuw huisvest tegenwoordig het Museum Kebangkitan Nasional (Museum van het Nationale Ontwaken),

\section{Vakverenigingen}

Zie Petrus Blumberger 1931:129-44, Tichelman 1985:14-7 en Ingleson 1986.

De Indische Partij en het Comité Boemi Poetra

Zie Petrus Blumberger 1939:32-9, Koch 1950:30-43, Glissenaar 1999:77-101, Van der Veur 2006:183-236 en Van Dijk 2007:45-71. Zie Van der Wal 1967:152-5 voor het gesprek van Douwes Dekker met gouverneur-generaal Idenburg. Voor de tekst van de brochure van Soewardi zie Poeze en Schulte Nordholt 1995:34-8. Voor het verblijf van de drie ballingen in Nederland zie Poeze 1986:91-5, 116-9, 137-40.

\section{De Sarekat Islam}

Zie Petrus Blumberger 1931:55-89, Korver 1982 en Shiraishi 1990:41-90. Zie Van der Wal 1967:161-4 voor het gesprek van gouverneur-generaal Idenburg met het bestuur van de Sarekat Islam.

Sneevliet en de Indische Sociaal-Democratische Vereeniging

Zie Petrus Blumberger 1931:106-10, 1935:1-8, 1939:41-4, McVey 1965:13-47 en Tichelman 1985:4-17, 25-9, 51-2. Zie over Semaoen ook Shiraishi 1990:98-103. Voor de verdedigingsrede van Sneevliet zie Baars en Sneevliet 1991.

Hoewel men ook binnen de reformistische rechtervleugel van de socialistische beweging soms wel naar de theorieën van Karl Marx verwees, zal de term 'marxisten' in dit boek uitsluitend gebruikt worden voor de leden van de radicale linkervleugel.

\section{De Politieke Inlichtingen Dienst}

Zie Tichelman 1985:463-4 en Poeze 1994.

De Indie Weerbaar-campagne

Zie Van der Wal 1967:459-89, Kwantes 1975:94-103, Tichelman 1985:21-4, 48-51, Poeze 1986:112-6 en Van Dijk 2007:255-86, 472-4, 579-90.

De instelling van de Volksraad

Over gouverneur-generaal Van Limburg Stirum zie Locher-Scholten 1981:55-117.

Uitzicht op geleidelijke dekolonisatie

Vergelijk Koch 1956:98-103, 116-25 en Van Dijk 2007:596-602. Voor de 'november-beloften' van gouverneur-generaal Van Limburg Stirum zie Van der Wal 1964:253-4, 604-5. 
Studenten in Nederland; de Indische Vereeniging en het Indonesisch Verbond van Studeerenden

Over de Indische Vereeniging zie Poeze 1986:63-81, 104-12, 134-40, 163. Over Ratoelangie zie Van Klinken 2003:85-113. Over het Indonesisch Verbond van Studeerenden zie Poeze 1986:127-34, 157-62 en Jonkman 1971:32-6.

Van Mook was op Java geboren en opgegroeid. Zijn ouders waren zelf in Nederland geboren, maar waren na hun huwelijk naar Indonesië gegaan om daar in het onderwijs te werken. Van Mook kwam pas op achttienjarige leeftijd in Nederland, studeerde daar eerst scheikunde en zwaaide vervolgens over naar de opleiding voor de Indische bestuursdienst. Na zes jaar verblijf in Nederland keerde hij in 1918 naar Indonesië terug. Steeds bleef Van Mook zich meer verbonden voelen met zijn Indonesische geboorteland dan met zijn Nederlandse vaderland.

Verharding van het Nederlands koloniaal beleid

De belangrijkste brochures waren Colijn 1918 en Treub 1923. Zie ook Brouwer 1958 en Henssen 1983. De in 1923 ingevoerde strafbepaling tegen het aanzetten tot staking was artikel 161 bis van het Wetboek van strafrecht voor Nederlandsch-Indië.

Het Indo-Europeesch Verbond

Zie Petrus Blumberger 1939:49-62.

De Nationaal-Indische Partij

Zie Petrus Blumberger 1939:45-8, Glissenaar 1999:125-38 en Van der Veur 2006:40340.

De wilde scholen

Zie Groeneboer 1993:365-8. Over de Moehammadiah zie Petrus Blumberger 1931:92-8; over het schoolsysteem van Tan Malaka zie Poeze 1976:121-33; over de Taman Siswascholen zie Tsuchiya 1987, over het Ksatrian Instituut zie Van der Veur 2006:471-537.

De machtsstrijd tussen de Sarekat Islam en de marxisten

Zie Petrus Blumberger 1931:64-79, 1935:15-47, McVey 1965:48-197 en Poeze 1976:14166. Zie over de Sarekat Islam Afdeling B ook Kwantes 1975:136-97. Zie over de vakbeweging en de pandhuisstaking ook Ingleson 1986:124-7, 214-6, 220-7.

Hervorming van het Nederlands-Indische staatsbestel

Vergelijk Koch 1956:123-5. Over het Comité voor de Autonomie van Indië zie Van der Wal 1964:504-6. Voor de 'Indische Staatsregeling' van 1925 zie Engelbrecht 1939:3771 .

De Ondernemersraad voor Nederlandsch-Indië en de Utrechtse indologenopleiding

Over de Ondenemersraad zie Taselaar 1998:108-18, 156-60. Over de Utrechtse opleiding zie Hekman 1981:6-7, Henssen 1983:51-65 en Fasseur 1993:412-33. Voor de opmerkingen van Snouck Hurgronje zie zijn artikel 'Vergeten jubilés'. Voor de opening van de nieuwe opleiding in Utrecht zie Kohlbrugge 1927. 
Studenten in Nederland; de Perhimpoenan Indonesia

Zie onder meer Hatta 1928, Petrus Blumberger 1931:183-96, Ingleson 1975 en Poeze 1986:175-82, 186-92, 209-20, 244-50, 257-73. Voor biografieën van Hatta zie Noer 2002 en Rose 1987; voor een biografie van Sjahrir zie Mrázek 1994. De drie in 1927 samen met Hatta gearresteerde PI-leiders waren Ali Sastroamidjojo, Abdoelmadjid Djojoadhiningrat en Mohammad Nazir Datoek Pamontjak. Voor het vonnis van de Haagse rechtbank uit maart 1928 zie Petrus Blumberger 1931:438-43.

De studieclubs van Soetomo en Soekarno

Zie Petrus Blumberger 1931:197-203. Over Soetomo zie Van der Veur 1987. Biografieën van Soekarno zijn onder meer Dahm 1964, Giebels 1999, Hering 2002, Legge 1972 en Penders 1980. Zie voor invloeden op zijn politieke vorming vooral Dahm en Hering.

Soekarno had geen voornaam. Dat zijn naam niettemin soms als Achmed Soekarno wordt weergegeven gaat terug op de tijd kort na de Tweede Wereldoorlog, toen Amerikaanse journalisten in Batavia door hun redacties werden aangemaand om Soekarno's naam volledig weer te geven en daarom de voornaam Achmed kozen om van deze aanmaningen verlost te worden.

Mislukte communistische opstand

Zie Petrus Blumberger 1935:55-106, McVey 1965:257-355 en Poeze 1976:294-360.

Boven-Digoel

Zie Petrus Blumberger 1935:107-23 en Salim 1973.

De vertrouwenspolitiek van De Graeff

Zie Ingleson 1979:36-45. Over Thamrin zie Hering 1997. Over de internering van Tjipto Mangoenkoesoemo zie Kwantes 1978:578-88.

De eerste nationalistische massabeweging: Soekarno's PNI

Zie Petrus Blumberger 1931:204-49, Ingleson 1975:44-9 en 1979:29-100 en verder Hering 2002:129-84. Over de PPPKI zie Petrus Blumberger 1931:250-74 en Ingleson 1979:46-52, 69-74.

Het Indonesisch Jeugdcongres van 1928

Zie Petrus Blumberger 1931:390-5 en Van Miert 1995:327-34. Over Amir Sjarifoeddin zie Van Klinken 2003:115-50.

De 'Inlandse meerderheid' in de Volksraad

Zie Brouwer 1958:123-9 en Van der Wal 1965:1-67.

De Vaderlandsche Club

Zie Drooglever 1980.

\section{Rijkseenheid}

Zie onder meer Treub 1927:53, 56, Colijn 1928:45 en Nederburgh 1929. Zie over De Rijkseenheid ook Hekman 1981:8-10 en Taselaar 1998:327-32. Nederburgh was in Batavia president van het Hooggerechtshof en directeur van het departement van justitie geweest. 
De Stuw-groep

Zie Locher-Scholten 1981:118-49.

Het proces-Soekarno

Over kritiek van andere nationalisten op het provocatieve optreden van Soekarno zie Ingleson 1979:82-89. Over het proces zie Hering 2002:185-213. Voor Soekarno's eigen pleitrede zie Soekarno 1931. De in 1930 samen met Soekarno berechte PNI-leiders waren Gatot Mangkoepradja, Maskoen en Soepriadinata. Voor een uittreksel uit het vonnis van de landraad in Bandoeng zie Petrus Blumberger 1931:444-53. Voor de door de Stuw-groep uitgegeven brochure Het vonnis in de P.N.I. zaak door J.M.J. Schepper zie Locher-Scholten 1981:125-6.

Hergroeperingen binnen de Indonesische vrijheidsbeweging

Zie Pluvier 1953:45-52 en Ingleson 1979:141-175. Verscheidene cursisten van Soekarno's kaderschool in Bandoeng, onder wie Soekarni, Trimoerti en Wikana, speelden later een belangrijke rol in de nationale beweging en kwamen daarbij soms tegenover Soekarno te staan.

Verzet tegen de wilde-scholenordonnantie

Zie Pluvier 1953:53-7 en Kwantes 1981:678-81. Voor de mening van gouverneurgeneraal De Jonge over het risico dat Dewantoro een Gandhi zou worden zie Van der Wal 1968:152.

Muiterij op 'De Zeven Provinciën'

Zie Blom 1975.

Onderdrukking van de Indonesische vrijheidsbeweging

Zie Pluvier 1953:57-63. Over de eerdere muilkorfcirculaire zie p. 137. Over Soekarno's morele inzinking zie Hering 2002:233-6. Voor de tekst van Soekarno's brieven van september 1933 zie Kwantes 1982:37-43. Over de PID zie Idenburg 1984:142-4 en Poeze 1994. Over de politieke voorlichting van het gouvernement door de PID-leiding zie Poeze PPO I:vii-ix. Zie voor een beeld van de nationale beweging in dit tijdsgewricht ook Soewarsih Djojopoespito 1940.

Het einde van de non-coöperatiepolitiek

Zie Pluvier 1953:57-63 en 94-117. De Sarekat Islam had haar naam in 1930 gewijzigd in Partai Sarekat Islam Indonesia (PSII). Over Kartosoewirjo zie Van Dijk 1981:20-40.

India, Birma en de Filippijnen op weg naar dekolonisatie

Zie onder meer Bootsma 1986.

De petitie-Soetardjo

Zie Pluvier 1953:118-29, Van der Wal 1965:219-318, 377-403, Abeyasekere 1973 en Gouka 2001. Over het herstel van inheemse vorstendommen zie Kleintjes 1938. 
Het eenheidsfront Gapi en de campagne 'Indonesië parlementair'

Zie Pluvier 1953:130-47, Van der Wal 1965:403-22, 492-535, Abeyasekere 1976:1148 en L. de Jong 1984:432-9. Over het verblijf van Hatta en Sjahrir op de Bandaeilanden vergelijk Sjahrazad 1945; daarin wordt Hatta aangeduid als 'Hafil', Tjipto Mangoenkoesoemo als 'Soeribno' en Iwa Koesoema Soemantri als 'Soebana'. Over de verwelkoming van Soekarno in Zuid-Sumatra zie Jaquet 1978:23. Over Kritiek en Opbouw zie Locher-Scholten 1981:150-75.

De maatschappelijke positie van de Indonesiërs omstreeks 1940

Vergelijk Beynon 1995. Veel gegevens hierover zijn ook te vinden in de memoires van prominente Indonesiërs, waaronder verschillende in Memoar.

Nederland in oorlog met Duitsland

Over de onwil van koningin Wilhelmina om in te stemmen met een bezoek van kroonprinses Juliana aan Nederlands-Indië zie Van der Wal 1968:77, 88.

De defensiecapaciteit van Nederlands-Indië

Zie L. de Jong 1984:600-62.

Bevriezing van het koloniale bestel

Zie Pluvier 1953:167-78, Van der Wal 1965:551-3, 597-603, 651-3, 680-9, Jonkman 1971:167-8, 178-83, 188-90, 231 en Abeyasekere 1976:54-69. Voor de rede van Thamrin zie Handelingen Volksraad 1940-1941:782-5; vergelijk Poeze PPO IV:382-4.

De laatste confrontaties tussen de nationale beweging en het koloniale gezag

Zie Pluvier 1953:178-93, Abeyasekere 1976:69-83 en L. de Jong 1984:571-99.

Nederland in oorlog met Japan

Zie L. de Jong 1984:696-727. Over de houding van de Indonesische nationalisten L. de Jong 1984:942-56, Abeyasekere 1976:83-5 en Touwen-Bouwsma 1992.

Verwijdering van niet-Indonesische geïnterneerden uit Nederlands-Indië

Zie Van Heekeren 1983 en L. de Jong 1984:727-39. Zie over de overbrenging van de Nederlandse geïnterneerden naar Suriname ook Glissenaar 1999:185-95 en Van der Veur 2006:575-98.

Verloop van de oorlog tot maart 1942

Zie L. de Jong 1984:712-968.

De Nederlandse capitulatie

Zie L. de Jong 1984:1-18 en 969-1038. 